ESCOLA POLITÉCNICA DA UNIVERSIDADE DE SÃO PAULO DEPARTAMENTO DE ENGENHARIA METALÚRGICA E DE MATERIAIS

EDITH MARIE MALATEAUX DE SOUZA

ADESIVO DE CONTATO DE POLICLOROPRENO BASE AQUOSA NANOADITIVADO E CONDICIONADO MAGNETICAMENTE 
EDITH MARIE MALATEAUX DE SOUZA

ADESIVO DE CONTATO DE POLICLOROPRENO BASE AQUOSA NANOADITIVADO E CONDICIONADO MAGNETICAMENTE

Tese apresentada à Escola Politécnica da Universidade de São Paulo para a obtenção do título de Doutor em Ciências

Área de Concentração:

Engenharia Metalúrgica e de Materiais

Orientador: Prof. Dr. Hélio Wiebeck 
EDITH MARIE MALATEAUX DE SOUZA

\section{ADESIVO DE CONTATO DE POLICLOROPRENO BASE AQUOSA NANOADITIVADO E CONDICIONADO MAGNETICAMENTE}

Tese apresentada à Escola Politécnica da Universidade de São Paulo para a obtenção do título de Doutor em Ciências

Área de Concentração:

Engenharia Metalúrgica e de Materiais

Orientador: Prof. Dr. Hélio Wiebeck 
Este exemplar foi revisado e corrigido em relação à versão original, sob responsabilidade única do autor e com a anuência de seu orientador.

São Paulo, de de

Assinatura do autor:

Assinatura do orientador:

\section{Souza, Edith Marie Malateaux de}

Adesivo de contato de policloropreno base aquosa nanoaditivado e condicionado magneticamente / E. M. M. Souza -- versão corr. -- São Paulo, 2015.

$95 \mathrm{p}$.

Tese (Doutorado) - Escola Politécnica da Universidade de São Paulo. Departamento de Engenharia Metalúrgica e de Materiais.

1.Adesivo de contato 2.Catálise 3.Condicionamento magnético 4.Nanoaditivos 5.Policloropreno I.Universidade de São Paulo. Escola Politécnica. Departamento de Engenharia Metalúrgica e de Materiais II.t. 
Dedico este trabalho ao meu amor. 


\section{AGRADECIMENTOS}

Ao meu mestre Paramahansa Yogananda pelos ensinamentos de força, persistência e coragem.

Ao meu marido, companheiro e amigo, pela paciência, cuidado, dedicação e amor.

Ao professor Dr. Hélio Wiebeck, por me receber como sua orientanda, pela orientação, pela confiança e pelo constante estímulo durante todo o trabalho.

Ao amigo Dr. Wanderley da Costa, pela ajuda, dedicação e parceria.

À Mantenedora da Fundação Educacional João Ramalho, em especial ao Dr. Ariovaldo José Pécora e à Dra. Luciana Della Sedie Pécora.

À diretoria da empresa Brascola.

Ao departamento de desenvolvimento e pesquisa da empresa Covestro.

Ao meu colega de trabalho Felipe Matos Lopes. 
A melhor coisa que você pode fazer para cultivar a verdadeira sabedoria, é praticar a consciência de que o mundo é um sonho. 


\section{RESUMO}

Atualmente, os adesivos de contato de policloropreno base aquosa, possuem capacidade de adesão, variando entre 1,15 até 2,75 kgf/ $\mathrm{cm}^{2}$. Em contrapartida, os adesivos de policloropreno base solvente, suportam tensões médias de cisalhamento de $3,8 \mathrm{kgf} / \mathrm{cm}^{2}$. Esta pesquisa apresenta uma proposta inovadora de condicionamento magnético do adesivo de contato de policloropreno base aquosa com o objetivo de aumentar a capacidade de aderência entre o adesivo e o substrato. Para promover um incremento na capacidade de adesão do adesivo de policloropreno base aquosa, formulou-se um adesivo utilizando um nanoaditivo, o gás carbônico como catalisador e um processo de condicionamento magnético precedente à etapa de aplicação sobre os substratos. Os resultados obtidos demonstraram aumento médio de 292 \% na tensão de cisalhamento do adesivo condicionado magneticamente quando comparado com o adesivo de mesma formulação sem o condicionamento magnético, e quando comparado com um adesivo comercial de policloropreno base aquosa, o aumento foi de $122 \%$.

Palavras chave: Adesivos de contato. Catálise. Condicionamento magnético. Nanoaditivos. Policloropreno. 


\begin{abstract}
Currently, the aqueous based polychloroprene contact adhesive presents an adhesion capacity variation between 1,15 and up to $2,75 \mathrm{kgf} / \mathrm{cm}^{2}$. However, the solvent based polychloroprene adhesives support average tensions of shearing of $3,8 \mathrm{kgf} / \mathrm{cm}^{2}$. This research is an innovative proposal for magnetic conditioning of the aqueous based polychloroprene contact adhesive with the purpose of increasing the adherence capacity between the adhesive and the substrate. To promote an increase of adhesion to the aqueous based polychloroprene contact adhesive, we formulated one adhesive using a nano-additive, carbon dioxide as catalyst, and a magnetic conditioning process before the phase of application on the substrates. The results obtained show an average increase of $292 \%$ in the shearing tension of the adhesive magnetically conditioned when compared with an adhesive of the same formulation without the magnetic conditioning and $122 \%$ increase when compared to the commercial aqueous based polichloroprene adhesive.
\end{abstract}

Keywords: Contact adhesives. Catalysis. Magnetic conditioning. Nano-additives. Polychloroprene. 


\section{LISTA DE ILUSTRAÇÕES}

$\begin{array}{lll}\text { Ilustração } 1 \quad \text { A multidisciplinariedade da ciência da adesão } & 13\end{array}$

Quadro $1 \quad$ Datas e eventos de referência da história dos adesivos

Ilustração 2 Diagrama representativo: adesão, aderência, coesão e coerência

Ilustração 3 Esquema de uma junta adesiva

Ilustração 4 Ancoragem do adesivo no substrato (hastes azuis)

Ilustração 5a Ângulo de contato

Ilustração 5b Superfícies polares e apolares, molhabilidade ou umectação.

Ilustração 6 Tempos envolvidos em um processo de colagem

Ilustração 7 Esquemas representativos das fórmulas estruturais do isopreno e cloropreno

Ilustração 8 Configurações do cloropreno

Ilustração 9 Diferentes configurações do cloropreno em função da temperatura de polimerização

Ilustração 10 Resistência à tração $\mathrm{x}$ alongamento para composições de elastômeros de policloropreno com negro de fumo

Ilustração 11 Parâmetros de vulcanização de composições de elastômeros de policloropreno com negro de fumo

Ilustração 12 Esquema representativo do mecanismo de degradação do policloropreno

Ilustração 13 Esquema representativo da produção da matriz polimérica de policloropreno base aquosa

Ilustração 14 Formulação básica de adesivo de policloropreno base solvente e base aquosa

Ilustração 15 Preparação dos corpos de prova

Ilustração 16 Politriz Lixadeira Metalográfica 65

Ilustração $17 \quad$ Pesagem das matérias primas 66

Ilustração 18 Preparação do adesivo 
Ilustração 19 Finalização da formulação

$\begin{array}{llc}\text { Ilustração } 20 \text { a } \quad \text { Verificação do pH } & 68\end{array}$

$\begin{array}{lll}\text { Ilustração } 20 \text { b Verificação da viscosidade } & 68\end{array}$

$\begin{array}{lll}\text { Ilustração } 21 \quad \text { Célula magnética } & 69\end{array}$

$\begin{array}{lll}\text { Ilustração } 22 \text { a União das peças de substrato } & 70\end{array}$

Ilustração 22 b Aplicação de pressão sobre os corpos de prova

$\begin{array}{lll}\text { Ilustração } 23 & \text { Equipamento Eco Mini }\end{array}$

Ilustração 24 a Pistola para aplicação de adesivos bicomponentes (líquido gás) 72

$\begin{array}{lll}\text { Ilustração } 24 \text { b Vista do bico de aplicação } & 73\end{array}$

Ilustração 25 Montagem do sistema completo de aplicação do adesivo base $\quad 73$ aquosa catalisado com $\mathrm{CO}_{2}$.

Ilustração 26 Aplicação do adesivo concomitantemente com o gás carbônico $\quad 74$ sem condicionamento magnético.

Ilustração 27 Substratos prontos para serem colados (fórmica à esquerda e Ipê 75 à direita).

Ilustração 28 Dinamômetro Instron modelo 3367

Ilustração 29 Resultados do ensaio de tração para os grupos A3 (COVESTRO 80 SCM) e A4 (COVESTRO CCM)

Ilustração 30 Resultados do ensaio de tração para os grupos A2 (Adesivo base 81 aquosa Henkel), A3 (COVESTRO SCM) e A4 (COVESTRO CCM)

Ilustração 31 Resultados do ensaio de tração para os grupos A1 (Adesivo base solvente Colabras), A2 (Adesivo base aquosa Henkel), A3 (COVESTRO SCM) e A4 (COVESTRO CCM)

Ilustração 32 Dados organizados em ordem crescente para análise estatística

Ilustração 33 Resultados comparativos do ensaio de tração para os grupos A1 (Adesivo base solvente Colabrás), A2 (Adesivo base aquosa Henkel), A3 (COVESTRO SCM) e A4 (COVESTRO CCM)

Ilustração 34 Resultados obtidos em função das variáveis estudadas 


\section{LISTA DE TABELAS}

Tabela 1 Mercado de adesivos e selantes

Tabela 2 Capacidade de suporte de aplicação de carga de alguns tipos de adesivos

Tabela 3 Formulação inicial típica para um adesivo de contato base solvente de policloropreno

Tabela 4 Propriedades do Dispercoll ${ }^{\circledR} \mathrm{C} 84$

Tabela 5 Formulação do adesivo de contado de policloropreno base aquosa

Tabela 6 Resultados do ensaio de sólidos totais

Tabela 7 Resultados do ensaio de tração e tensão de cisalhamento em $\mathrm{kgf} / \mathrm{cm}^{2}$ 79

Tabela 8 Resultados das análises estatísticas 


\section{SUMÁRIO}

1 INTRODUÇÃO 12

$\begin{array}{ll}1.1 & 12\end{array}$

$\begin{array}{lll}1.2 & \text { OBJETIVOS } & 17\end{array}$

$1.3 \quad$ ORIGINALIDADE E JUSTUFUCATUVA DO TRABALHO 18

2 FUNDAMENTAÇÃO TEÓRICA 19

$\begin{array}{ll}2.1 & \text { ADESIVOS: UMA BREVE HISTÓRIA }\end{array}$

2.2 CONCEITOS FUNDAMENTAIS 22

$\begin{array}{lll}2.3 & \text { TEORIAS DA ADESÃO }\end{array}$

$\begin{array}{lll}\text { 2.3.1 } & \text { Teoria de Interligação Mecânica } 28\end{array}$

$\begin{array}{lll}\text { 2.3.2 } & \text { Teoria de Adsorção } & 29\end{array}$

$\begin{array}{lll}\text { 2.3.3 Teoria da Difusão } & 32\end{array}$

2.3.4 Teoria das camadas de bordas fracas 32

2.3.5 Teoria da tensão crítica superficial dos substratos 32

2.4 CARACTERÍSTICAS DOS ADESIVOS 33

2.5 CLASSIFICAÇÃO DOS ADESIVOS 34

3 ESTADO DA ARTE: ADESIVOS DE POLICLOROPRENO 36

3.1 POLICLOROPRENO 36

3.2 SÍNTESE DE POLICLOROPRENO 39

3.3 ADESIVOS DE POLICLOROPRENO 39

$\begin{array}{lll}\text { 3.3.1 } & \text { Adesivo de policloropreno base solvente }\end{array}$

3.3.1.1 Propriedades dos adesivos de policloropreno base solvente 42

3.3.1.2. Formulações típicas para o adesivo de policloropreno base solvente 47

3.3.2 Adesivo de contato de policloropreno base aquosa 49 
4 CONDICIONAMENTO MAGNÉTICO DE POLÍMEROS NANOESTRUTURADOS E DE SOLUÇÕES AQUOSAS

5 MATERIAIS E MÉTODOS 62

5.1 MATERIAIS 62

$\begin{array}{lll}5.2 & \text { MÉTODOS } & 64\end{array}$

6 RESULTADOS E DISCUSSÃO

$\begin{array}{lll}6.1 & \text { VISCOSIDADE } & 77\end{array}$

6.2 TEMPO EM ABERTO 77

6.3 TENSÃO DE CISALHAMENTO 78

6.4 ANÁLISE ESTATÍSTICA DOS RESULTADOS 83

7 CONCLUSÕES

8 CONSIDERAÇÕES FINAIS 90

REFERÊNCIAS 91 


\section{INTRODUÇÃO}

\subsection{CONSIDERAÇÕES GERAIS}

Os adesivos e selantes são materiais notáveis e as tecnologias utilizadas para a produção e aplicação desses materiais são igualmente extraordinárias. É difícil imaginar um produto, em casa, na indústria, no transporte ou em qualquer outro lugar que não utilize algum tipo de adesivo ou selante. Com base neste fato, pode-se afirmar que os adesivos e selantes estão presentes em todos os segmentos da economia e por isso têm seu desempenho comercial atrelado diretamente ao desempenho desses setores. Atualmente, esse mercado representa em torno de $2 \%$ do PIB no Brasil e tem grande parte do volume de produção distribuído entre poucas empresas, ou seja, calcula-se que 38 fabricantes representem cerca de $80 \%$ de todas as vendas do setor (ABIQUIM, 2011).

Por outro lado, é um setor bastante segmentado, com destaque para o setor da construção civil, que representa em torno de $50 \%$ do consumo de adesivos, colas e selantes; o setor automotivo, o de embalagem, calçadista, moveleiro, da indústria em geral e o mercado de consumo. Em relação às tecnologias, também há uma segmentação, com os adesivos e colas base água liderando com 48,15\% do mercado. Em seguida, aparecem os produtos que utilizam tecnologia base solvente, com 24,4\%; os adesivos sólidos, incluindo o hotmelt com 12,25\%; e os selantes, com 15,2 \% (LATINCOAT \& ADHESIVES, 2012).

Com base neste cenário, pode-se inferir que a indústria de adesivos e selantes enfrenta alguns desafios. O primeiro deles refere-se ao crescimento do mercado, impulsionado até pela ascensão social e econômica da população brasileira, bem como de alguns fatores pontuais e externos, como a realização de alguns eventos de cunho mundial no país. O segundo desafio está relacionado com o desenvolvimento do mercado, que solicita novas soluções para serem usadas em novos produtos, levando em conta os desdobramentos de tecnologias novas da indústria química, o desenvolvimento de materiais novos, a substituição de processos mecânicos de junção por colagem, o aumento de eficiência nos processos de aplicação, a colagem de materiais novos, o desenvolvimento de produtos amigáveis ao meio ambiente e o atendimento a requisitos legais, ou seja, as empresas devem se empenhar em produzir e oferecer soluções sustentáveis e inovadoras.

No caso do setor de calçados e móveis em especial, outro desafio das empresas é a pulverização dos polos produtivos destes produtos, que se encontram distribuídos entre todos 
os estados da federação, e, além disso, a maioria das empresas dessas áreas é de micro e pequeno porte (ABIQUIM, 2011).

Não se pode esquecer ainda de analisar a questão da matéria prima e das fontes energéticas, que atualmente são elementos que buscam alternativas mais viáveis.

Como visto, em se tratando de produtos de aplicação ampla e complexidade alta de formulação, para se desenvolver e produzir adesivos ou selantes, é necessário um conhecimento multidisciplinar, e o mercado não tem recebido profissionais com esta preparação tão abrangente. Porém, reside nesta multidisciplinariedade a natureza encantadora do trabalho com esses materiais. Com a Ilustração 1, pretende-se mostrar o encadeamento multidisciplinar da ciência da adesão.

Ilustração 1- A multidisciplinariedade da ciência da adesão

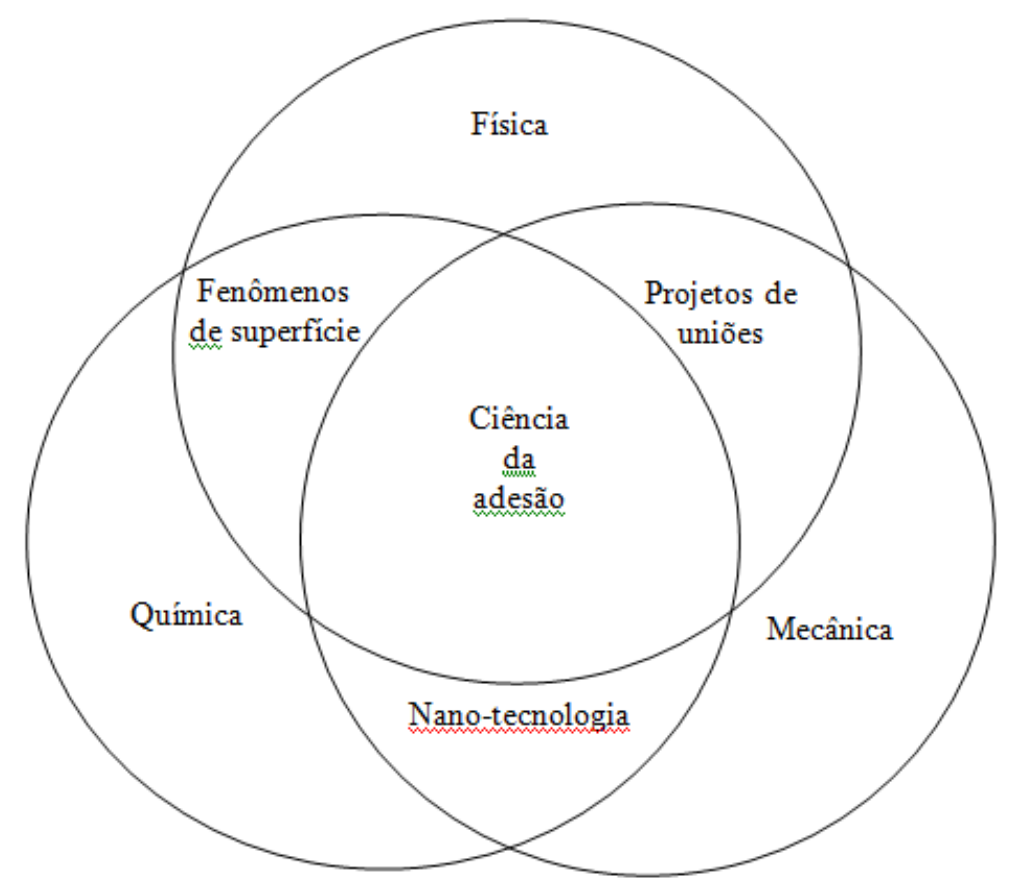

Fonte: Adaptado de PETRIE, 2007

A ciência de materiais contribui com conhecimentos expressivos para a solidez das descobertas na área dos adesivos. Dentro da área da química, o conhecimento profundo da química orgânica, ciência dos polímeros e nanotecnologia, é essencial para o desenvolvimento de adesivos novos e selantes. Além dos fenômenos de superfície, mecânica, projetos de uniões, uma área da física em especial, o magnetismo e a aplicação de campos magnéticos, 
que será abordada com destaque nesta tese, por se tratar de uma aplicação inovadora e inédita neste campo de trabalho é muito promissora.

Atualmente existe uma demanda por produtos ambientalmente amigáveis, e os adesivos e selantes não poderiam ficar fora dessa tendência, portanto tecnologias e materiais novos são desenvolvidos com esta finalidade, levando em conta a manutenção do desempenho alto e produtividade.

Os mercados de adesivos e selantes de qualidade alta, como o de epóxi, silicone e poliuretano tem crescido rapidamente, e os motivos desse crescimento estão relacionados ao nível baixo de poluentes desses produtos, pois eles podem ser produzidos em base aquosa, ao invés da base solvente. Mercados novos utilizam estes produtos, como a área médica e materiais novos de construção.

Ampliando o conhecimento sobre as áreas de aplicação dos adesivos e selantes, apresentam-se, na Tabela 1, os segmentos de mercado que utilizam estes produtos e alguns exemplos de aplicação.

Tabela 1- Mercado de adesivos e selantes

\begin{tabular}{ll}
\hline \multicolumn{1}{c}{ Segmentos de mercado } & \multicolumn{1}{c}{ Exemplo de aplicação } \\
\hline Automotivo & Selantes de vidros, selantes de interior \\
Construção & $\begin{array}{l}\text { Juntas, material corta fogo, envidraçamento, } \\
\text { assentamento de pisos e telhados }\end{array}$ \\
Aeroespacial & Tanque de combustível, janelas, juntas \\
Vidros isolantes & Envidraçamento, instalações, refrigeração \\
Industrial & \\
Construção pesada & $\begin{array}{l}\text { Montagens, containers, elétrico/eletrônicos, } \\
\text { fios e cabos, selantes }\end{array}$ \\
Marinha & Pontes, estradas, túneis, selante de tubos \\
\hline
\end{tabular}

Fonte: Adaptado de PETRIE, 2007

As ligações ou juntas adesivas por sua vez, apresentam vantagens e desvantagens intrínsecas ao processo de ligação. Em termos de vantagens, destacam-se as seguintes: 
a) as ligações adesivas oferecem a possibilidade de unir materiais diferentes, como por exemplo metais, plásticos, compósitos, madeira entre outros, pois o adesivo impede contato íntimo, o que de outro modo poderia conduzir a corrosão galvânica;

b) os adesivos têm a capacidade de unir chapas finas de forma eficiente. É principalmente relevante para produção de veículos ou estruturas leves;

c) uma junta bem projetada terá capacidade de absorver energia, isto é, tende a ter boas propriedades de amortecer e absorver vibrações e sons;

d) o adesivo pode ter uma finalidade dupla uma vez que, além de proporcionar a resistência mecânica, também pode vedar a junta contra a entrada de umidade e detritos;

e) comparado com uniões por rebites ou parafusos, as uniões adesivas distribuem a carga de uma maneira uniforme minimizando assim as concentrações de tensões. Como resultado, os problemas de fadiga são minimizados;

f) a união adesiva é muitas vezes uma técnica conveniente e de custo baixo. A automação do processo com o uso de robôs minimiza a necessidade de qualquer interação humana e, com o aumento do desenvolvimento dos sistemas de fabrico flexíveis, a ligação adesiva pode ser uma parte integrante da linha de montagem (KARAČ, 2008).

As desvantagens mais importantes das ligações adesivas estão relacionadas com os seguintes aspetos:

a) o pré-tratamento dos substratos é muito importante para a qualidade da união e tem um grande efeito sobre a resistência da junção, em particular, sob condições ambientais severas;

b) a ligação adesiva tem uma gama de temperaturas de serviço limitado em comparação com outros tipos de ligações mecânicas;

c) a força e a tenacidade dos adesivos são geralmente baixas em comparação com os metais, e, por conseguinte, limitam a sua aplicação;

d) as juntas adesivas são inerentemente fracas em relação às forças de arrancamento;

e) há uma falta de informação e conhecimento sobre o comportamento das juntas adesivas em condições de impacto;

f) as ligações adesivas não permitem desmontagem;

g) as propriedades dos adesivos são bastantes variáveis, o que torna a escolha difícil para uma determinada aplicação (KARAČ, 2008).

Tendo em vista as vantagens e as limitações da utilização dos adesivos e selantes, um empenho por desenvolver novas composições, tecnologias para produção e aplicação dos 
adesivos vêm sendo desenvolvidas, fornecendo a este universo um avanço de importância relevante.

Para atender tantos tipos de aplicações, a existência de centenas de preparações adesivas, além das constantes inovações tecnológicas que surgem a cada dia, as necessidades de mercado criaram um cenário de variáveis extensas, porém, não se pode perder de vista, que para o produto ser aceito, além de eficiente, ele precisa apresentar uma relação custo benefício que possibilite sua inserção neste mercado, para isto, é de suma importância trabalhar intensivamente para conhecer e escolher o adesivo a ser utilizado, visto que diversos deles podem ser empregados para manter unidas, por adesão superficial, peças diferentes e em condições diferentes (BORRACHA ATUAL, 2007).

Até o momento foi feita a apresentação de um cenário geral sobre o universo dos adesivos e selantes, porém esta tese tem como objeto de estudo o adesivo de policloropreno, muito utilizado atualmente como referência de aplicação na indústria moveleira para colagem de fórmicas e tapeçaria. Este tipo de adesivo pode ser apresentado tanto em formulações base solvente como base aquosa.

Tradicionalmente, há uma preferência, neste segmento, pela utilização dos adesivos de policloropreno base solvente. As formulações do referido adesivo apresentam várias vantagens de uso, tais como aderência sobre uma enorme variedade de substratos, pega imediata, desenvolvimento de boa coesão e resistência ao envelhecimento e resistência à degradação química, porém, com a necessidade da substituição de substâncias provenientes de recursos não renováveis por outras, provenientes de recursos renováveis, além de causar impactos menores ao meio ambiente, tanto durante o processo de produção, como também durante a aplicação do produto, novas formulações na área e adesivos já podem ser encontradas, por exemplo, os adesivos de base aquosa, que têm uma eficiência significativa em suas aplicações, além de providenciar uma redução na emissão de compostos orgânicos voláteis (VOCs), durante sua aplicação.

Em tempos em que os processos químicos industriais estão passando por uma releitura, para que possam se adequar às condições ambientais presentes na atualidade, todo esforço utilizado para elaborar novas alternativas para as necessidades do mercado são importantes.

É sabido que solventes, como o tolueno, têm a tendência de deixar de fazer parte de formulações em geral em um futuro próximo, portanto é inevitável que novas propostas sejam desenvolvidas para cumprimento desta determinação. Muitas empresas já substituíram o tolueno por outros solventes orgânicos, mas, não seria interessante apenas substituir esta 
substância por outra, também proveniente de recursos não renováveis e com todas suas implicações em relação ao meio ambiente e à saúde das pessoas que as manuseiam.

A alternativa de substituição do solvente orgânico por água é bastante adequada, pois causaria redução de riscos processuais e de aspectos e impactos ambientais.

$\mathrm{O}$ avanço da tecnologia na área de adesivos de base aquosa também se deve ao custo alto de resinas e solventes orgânicos.

Atualmente, já existem no mercado, formulações para adesivos de policloropreno base aquosa, porém, o processo de aplicação deste adesivo, bem como algumas propriedades e características de adesão, em especial na indústria moveleira, ainda apresentam dificuldades técnicas, principalmente em relação ao tempo aberto desde adesivo, o que acaba levando os consumidores a utilizarem com restrições, pois alongam muito o processo produtivo. Resumindo, duas dificuldades técnicas de importância residem no tempo aberto do adesivo e na força de adesão. Portanto, este estudo dedica-se a apresentar respostas às seguinte questões:

Será possível melhorar o tempo aberto do adesivo de contato de policloropreno base aquosa para que ele seja competitivo com o adesivo de mesma matriz polimérica base solvente já utilizado no mercado moveleiro, sem causar impedimentos nos equipamentos de aplicação deste adesivo?

Será possível melhorar o poder de adesão de um adesivo de policloropreno base aquosa, introduzindo uma etapa processual, utilizando aplicação de campos magnéticos após o adesivo formulado e anteriormente ao processo de aplicação sobre o substrato?

\subsection{OBJETIVOS}

Com base neste cenário, define-se que o objetivo geral desta pesquisa é propor inovações por meio da utilização de catalisadores que diminuam o tempo aberto do adesivo, inovação na forma de aplicação do adesivo de policloropreno base aquosa, bem como utilizar campos magnéticos precedendo o processo de aplicação do adesivo. Com isso espera-se ter uma formulação ambientalmente amigável, dentro do previsto na regulamentação, bem como um produto eficiente e economicamente viável.

Como objetivos específicos, elencam-se:

a) Apresentar uma fundamentação teórica consistente, bem como a nomenclatura específica da ciência da adesão, preliminarmente a abordagem do assunto específico. 
b) Apresentar uma proposta de aditivação da matriz polimérica utilizando antioxidante e espessante em escala nanométrica, juntamente com um sistema de catálise, utilizando gás carbônico, para que se consiga diminuir o tempo em aberto do adesivo de policloropreno base aquosa;

c) propor um sistema de condicionamento magnético do adesivo formulado como etapa precedente à aplicação do adesivo no substrato, com o intuito de incrementar as propriedades de adesão do referido adesivo;

d) apresentar uma proposta de aplicação do adesivo, utilizando gás carbônico, concomitante à aplicação do adesivo, resolvendo problemas técnicos provenientes de formas tradicionais de aplicação do adesivo;

d) realizar um estudo comparativo, no que diz respeito à força de adesão e tempo aberto, entre quatro grupos de amostra: adesivo de policloropreno base solvente, policloropreno base aquosa para aplicação com pincel, policloropreno base aquosa com aplicação spray, catalisado com $\mathrm{CO}_{2}$, e policloropreno base aquosa com aplicação spray catalisado com $\mathrm{CO}_{2}$ e condicionado magneticamente.

\subsection{ORIGINALIDADE E JUSTIFICATIVA DO TRABALHO}

Analisando-se os objetivos propostos, um questionamento sobre a utilização de condicionamento magnético em adesivos pode aparecer, pois isto é algo inusitado, e é neste fato que reside a originalidade desta pesquisa.

Pesquisou-se anteriormente ao curso de Doutorado, a aplicação de campos magnéticos em algumas áreas, como por exemplo, em parametrização de águas industriais, em soluções aquosas de fertirrigação, no comportamento de flora microbiana presente em soluções aquosas, na redução do consumo de água na produção de hortaliças, na produção de concreto, enfim, em áreas diferentes, porém com um elemento em comum, a água.

Nas pesquisas realizadas, observou-se que algumas substâncias presentes em soluções aquosas, tais como sais e óxidos, podem ser suscetíveis à aplicação de campos magnéticos. Portanto, inferiu-se que, sendo o adesivo em estudo, uma solução aquosa com nanoaditivos minerais, seria possível promover alguma modificação em alguma propriedade deste adesivo, quando condicionado magneticamente, e esta, foi a motivação deste estudo. 


\section{FUNDAMENTAÇÃO TEÓRICA}

Neste capítulo serão apresentados, além de um breve histórico sobre o desenvolvimento dos adesivos, conceitos básicos sobre adesivos, adesão, teorias de adesão, características dos adesivos, classificação dos adesivos e alguns tipos de adesivos, que servirão de fundamentação teórica para a compreensão do assunto principal a ser abordado que é o adesivo de policloropreno base aquosa, objeto de estudo desta tese.

\subsection{ADESIVOS: UMA BREVE HISTÓRIA}

Desde os tempos mais remotos existem manifestações a respeito do uso de substâncias adesivas. A primeira evidência de uma substância utilizada como adesivo data de 4.000 a.C., provavelmente derivados de seiva de árvores, porém tem-se notícia, na mesma época do emprego de cimentos betuminosos para unir ossos de marfim em estatuas da Babilônia. Esculturas em Tebas que datam de aproximadamente 3300 a.C., apresentam uma colagem de chapas delgadas em tábuas de madeira; os egípcios utilizavam adesivos de caseína, amido e açúcares para unir as folhas de papiro; os romanos aplicavam lâminas de ouro sobre papel, utilizando como adesivo a clara de ovo. Em 1365 a.C., na tumba de Tutamkamon foi encontrado um baú de cedro colado com adesivo de caseína. Entre 1500 e 1000 a.C. várias pinturas e murais mostravam detalhes de operações de adesão com objetos de madeira, demonstrando que a "cola" tenha se tornado em um método de montagem por união. Em documentos chineses, que datam de 100 a.C., descreve-se o uso de substâncias obtidas da boca do esturjão e utilizadas como "colas" aplicáveis na construção de barcos

No final do século XVII, na Holanda, tem-se o relato do aparecimento da primeira planta industrial para produção de "colas" utilizando como matéria prima substâncias de origem animal; no século XVIII, na Inglaterra, registrou-se a primeira patente de fabricação de "colas" com matéria prima originada de substâncias oriunda de pescados e finalizando este mencionado século, foi feita a patente do uso da borracha natural como adesivo (LIESA; BILURBINA, 1990).

Durante o século XIX se sucedem comercializações e diferentes patentes de adesivos com base nas substâncias já mencionadas. Já no final do século XIX, com o crescente desenvolvimento dos conhecimentos relacionados à Química Orgânica, registram-se as primeiras patentes de adesivos denominados orgânicos sintéticos que vão sendo desenvolvidos e incrementados durante as primeiras décadas do século XX. Os adesivos em 
questão são os adesivos de ureia formaldeído e fenólicos, começando a aparecer outras resinas de aplicação.

No período entre os anos de 1930 e 1950 o desenvolvimento dos adesivos orgânicos sintéticos alcança níveis cada vez mais elevados, e o laboratório de ensaios que sustentava "invenções" utilizadas durante a segunda guerra mundial, serviu de ajuda no desenvolvimento desses adesivos.

A partir de 1940, a utilização do adesivo como elemento de união estrutural na indústria aeronáutica, revolucionou o conceito de "pega" dos adesivos, possibilitando a execução de projetos que não eram possíveis anteriormente. (LIESA; BILURBINA, 1990).

Outros campos de aplicação foram experimentando a tecnologia dos adesivos, como por exemplo, a arquitetura, não só em materiais básicos como madeiras, bem como em conjunto com o cimento, com plásticos, alumínio, aço, em janelas, painéis de recobrimento, cúpulas, elementos interiores, esculturas, entre outros.

No setor alimentício, o adesivo tem permitido a evolução dos envasamentos, utilizando sistemas mais eficientes, mais práticos e mais econômicos, sem apresentar os problemas de corrosão que apresentavam os produtos metálicos.

A vantagem da tecnologia das resinas tem resultado em gerações novas de adesivos que combinam resistência grande ao esforço cortante, despelamento, desgarramento pelo impacto, um comportamento bom quando exposto a temperaturas altas ou condições severas ambientais.

Outro setor que introduziu o adesivo com maior incidência foi o setor automobilístico, que utilizou os adesivos não só como elemento de união de alguns elementos como vidros, retrovisores, juntas em portas e capôs e revestimentos interiores, mas também em aplicações estruturais, na construção da carroceria de veículos, baús de caminhões e compartimentos de caminhões frigoríficos.

Atualmente, se utilizam milhares de toneladas de produtos adesivos sintéticos, que tiveram um grande impulso em seu desenvolvimento, deixando praticamente como fator histórico a utilização dos adesivos antigos de origem vegetal e animal, especialmente pela resistência maior das uniões e a estabilidade grande frente aos agentes físicos, químicos e biológicos, pois a utilização de adesivos substitui vários tipos de fixação mecânicas, como soldas, rebites, parafusos, costuras e suturas; e além de ser uma evolução na forma de fixação.

A resistência e a estabilidade obtidas com a união adesiva não são os únicos critérios que decidem o uso adequado de um adesivo. Também é de importância grande a sua 
viabilidade econômica, e neste sentido, quanto mais simples o método de aplicação e quanto menor o tempo necessário para o processo, mais adequado será o adesivo.

A história da indústria moderna de adesivos está intimamente ligada ao desenvolvimento das indústrias de aeronaves e aeroespacial. Desde os primeiros voos até ao mais moderno equipamento aeroespacial, a massa do conjunto tem sido uma das considerações mais importantes. A ligação adesiva foi o método ideal de ligação nos antigos aviões a madeira e tecido, e hoje em dia é o método mais importante de união para o alumínio, titânio e outros metais em naves militares avançadas e espaciais, e também em alguns aviões comerciais atuais (PIZZI; MITTAL, 2003).

Com o intuito de organizar alguns eventos de referência durante o desenvolvimento dos diversos tipos de adesivos durante a história, apresenta-se o Quadro 1.

Quadro 1 - Datas e eventos de referência da história dos adesivos

\begin{tabular}{|c|c|}
\hline 1100 d.C. & $\begin{array}{l}\text { Surge a primeira colagem em caixas de madeira, para guarda moedas } \\
\text { utilizando-se adesivo a base de clara de ovo e cal }\end{array}$ \\
\hline 1690 d.C. & Fundada na Holanda a primeira indústria de cola animal \\
\hline 1754 d.C. & Cola de pescado patenteado pela primeira vez na Inglaterra \\
\hline 1797 d.C. & Adesivo de borracha natural, patenteado por Peal, Johnson na Inglaterra \\
\hline 1800 d.C. & Produção comercial de cola de caseína na Suíça e Alemanha \\
\hline 1823 d.C. & Produção comercial de adesivo de borracha natural \\
\hline 1825 d.C. & $\begin{array}{l}\text { Von Fuchs apresenta um estudo exaustivo sobre a utilização de silicatos } \\
\text { solúveis e sugere seu emprego em cimentos }\end{array}$ \\
\hline 1872 d.C. & Produção comercial de colas de pescados nos EUA \\
\hline 1910 d.C. & $\begin{array}{l}\text { Uma patente francesa sugere o uso de adesivos com resina fenólica. Surge } \\
\text { também na mesma época, a aplicação de silicatos solúveis para a colagem de } \\
\text { madeira }\end{array}$ \\
\hline 1914 d.C. & Patentes de Redman sobre adesivos a base de fenol-formaldeído \\
\hline 1915 d.C. & $\begin{array}{l}\text { Utilização de colas de albumina de sangue em embarcações e na indústria } \\
\text { aeronáutica }\end{array}$ \\
\hline 1917 d.C. & $\begin{array}{l}\text { Colas de caseína começam a ter importância comercial na construção } \\
\text { aeronáutica }\end{array}$ \\
\hline 1920 d.C. & John sugere, nos EUA, a patente de uréia-formaldeído como adesivo \\
\hline 1920/30 d.C. & Surgem adesivos a base de ésteres de celulose e resinas alquídicas \\
\hline 1928 d.C. & Surgem adesivos de cloropreno (McDonald,B.B. Chem ,Co.) \\
\hline
\end{tabular}


Quadro 1 - Datas e eventos de referência da história dos adesivos - continuação

\begin{tabular}{|l|l|}
\hline 1937 d.C. & Introdução de adesivos de uréia-formaldeído \\
\hline $1939 / 43$ d.C. & Adesivos epóxi, surge “Araldite" (Ciba) na Suíça e "Epon” (Shell) nos EUA \\
\hline $1939 / 44$ d.C. & Estudos dos poliuretanos, surge a marca "Desmodur" da Bayer na Alemanha \\
\hline $1942 / 46$ d.C. & $\begin{array}{l}\text { Introdução dos adesivos de poliuretano na indústria militar, durante a } \\
\text { segunda guerra mundial }\end{array}$ \\
\hline 1952 d.C. & Emprego de elastômeros carboxilados como adesivos \\
\hline $1955 / 57$ d.C. & Início da fabricação e comercialização dos adesivos de cianoacrilatos \\
\hline $1960 / 70$ d.C. & Utilização do termo adesivos estruturais \\
\hline 1960 d.C. & Desenvolvimento dos adesivos denominados nylon epóxi \\
\hline 1960 d.C. & Selante bi componente de poliuretano para a indústria da construção civil \\
\hline 1965 d.C. & $\begin{array}{l}\text { Desenvolvimento do adesivo de borracha termoplástica de copolímero em } \\
\text { bloco estireno-polibutadieno-estireno }\end{array}$ \\
\hline 1969 d.C. & Desenvolvimento de selantes de polimercaptanas \\
\hline 1970 d.C. & $\begin{array}{l}\text { Produção da segunda geração de adesivos acrílicos, } \\
\text { Desenvolvimento dos adesivos estruturais de poliuretano }\end{array}$ \\
\hline 1980 d.C. & Desenvolvimento de adesivos de contato base aquosa, em especial os epoxi \\
\hline 1990 d.C. & $\begin{array}{l}\text { Desenvolvimento de adesivos de poliuretano modificado com epóxi, cura } \\
\text { UV; cross-linked silano-poliuretano }\end{array}$ \\
\hline
\end{tabular}

Fonte: PETRIE, 2007; LIESA; BILURBINA, 1990

\subsection{CONCEITOS FUNDAMENTAIS}

Assim como todas as ciências têm se desenvolvido ao longo do tempo, a ciência que embasa o conhecimento sobre os adesivos e selantes desenvolveu uma nomenclatura própria, e neste capítulo, apresentam-se os principais termos e definições necessários para a compreensão das propriedades específicas dos adesivos e selantes.

Em primeiro lugar deve-se considerar as definiçõoes de adesivos e selantes. Estes são geralmente produzidos com base em materiais semelhantes e eles são algumas vezes utilizados em aplicações semelhantes também. No entanto, no caso dos adesivos, deve-se observar primeiramente a função adesiva e neste caso, estes produtos podem ser denominados simplesmente de adesivos. 
Entretanto, dependendo de outras funções determinadas para o produto adesivo, outras denominações podem ser-lhes atribuídas, portanto, segundo PETRIE, 2007 define-se:

a) Adesivo: substância capaz de manter unidas pelo menos duas superfícies de maneira forte e permanente.

b) Selante: substância capaz de anexar pelo menos duas superfícies de modo que haja o preenchimento do espaço entre elas providenciando uma barreira ou cobertura protetiva.

Muitos dos produtos podem ser considerados tanto como adesivos como selantes pois podem ao mesmo tempo aderir e vedar, podem ser resistentes ao ambiente ao qual forem expostos e suas propriedades são dependentes de como eles foram processados e posteriormente aplicados.

Tanto os adesivos como os selantes também compartilham de outras características comuns, como por exemplo, devem ser líquidos para que possam ser processados, e posteriormente secos, para fazer contato íntimo com o substrato sobre o qual foram aplicados; devem permitir o desenvolvimento de forças intermoleculares que promoverão a adesão, devem preencher falhas, cavidades e espaços, além de serem compatíveis com outros materiais, proporcionando facilidade de montagem dos produtos nos quais serão aplicados.

Os adesivos e selantes modernos são geralmente formulados tendo como base uma matriz polimérica, cargas, pigmentos, estabilizantes, plastificantes e outros aditivos que sejam necessários para conferir características específicas para o produto final. Os processos utilizados podem envolver misturas simples, bem como podem ser sofisticados, denominados processos de copolimerização.

Os adesivos são escolhidos pela capacidade de unir e aderir substratos, suportando tensões altas de cisalhamento.

Utilizam-se duas outras definições que diferenciam os adesivos entre si, que são: adesivos estruturais e adesivos não estruturais.

Os adesivos estruturais são aqueles em que a característica principal é a resistência às forças aplicadas, o que garante o sucesso de uma montagem. Este termo é utilizado para descrever adesivos que suportam tensões altas de cisalhamento (mais do que 1000 psi) e possuem resistência boa ao ambiente ao qual são expostos. Os adesivos estruturais geralmente são formulados com base em uma matriz polimérica termofixa, como epóxi ou poliuretano. São adesivos feitos para serem permanentes, ou seja, não são formulados para que posteriormente seja feita uma desunião entre os substratos.

Os adesivos não estruturais são adesivos que não suportam forças altas aplicadas e também não são permanentes. Eles são geralmente utilizados para colagens rápidas ou 
utilizados em substratos frágeis. Exemplos desses adesivos são filmes sensíveis a pressão, cola de madeira, hot melt (cola quente) e adesivos elastoméricos. Geralmente são formulados utilizando uma matriz polimérica termoplástica, como acrílica, poliacetato de vinila, ou polímeros celulósicos.

Os adesivos estruturais são classificados em função de sua tensão de cisalhamento ou força de união por unidade de área. Porém, os componentes da formulação, o tipo de substrato, sua geometria e fatores ambientais também devem ser levados em consideração para classificar um adesivo estrutural.

Os adesivos não estruturais por sua vez, são classificados em função da película formada entre os substratos bem como sua capacidade de resistir ao estresse mecânico necessário para separar os substratos.

Com a intenção de apresentar as capacidades de adesão, resultantes da aplicação de cargas em substratos utilizando vários tipos de adesivos, apresentam-se na Tabela 2, os valores de tensão de cisalhamento e carga aplicados sobre a película de alguns tipos de adesivos.

Tabela 2 - Capacidade de suporte de aplicação de carga de alguns tipos de adesivos

\begin{tabular}{lcc}
\hline \multicolumn{1}{c}{ Tipo de adesivo } & $\begin{array}{c}\text { Tensão de Cisalhamento } \\
(\mathrm{MPa})\end{array}$ & $\begin{array}{c}\text { Peel load } \\
(\mathrm{N} / \mathrm{m})\end{array}$ \\
\hline Adesivos sensíveis à pressão & $0,005-0,020$ & $300-600$ \\
Adesivos de matriz & $0,3-7,0$ & $1.000-7.000$ \\
elastomérica & & \\
Emulsão termoplástica & $10-14$ & - \\
Hot melt & $1-15$ & $1.000-5.000$ \\
Poliuretano & $6-17$ & $2.000-10.000$ \\
Acrílico & $6-20$ & $9.000-6.000$ \\
Epóxi & $14-50$ & $700-18.000$ \\
Fenólica & $14-35$ & $700-9.000$ \\
Poliamida & $13-17$ & $350-1.760$ \\
\hline
\end{tabular}

Fonte: PETRIE, 2007

Os selantes são geralmente escolhidos por sua capacidade de preencher espaços e resistir a movimentos dos substratos. Eles possuem capacidade menor de suportar aplicação de tensão de cisalhamento do que os adesivos estruturais, mas são mais flexíveis e possuem 
característica especial de elongação. Os selantes mais comuns são geralmente formulados a partir de matrizes poliméricas elastoméricas, bem como poliuretânicas, siliconadas e polisulfídicas.

Como os adesivos e selantes têm como função principal a propriedade de adesão, fazse necessário a apresentação da nomenclatura e de algumas definições de termos técnicos específicos relacionados aos fenômenos da ciência da adesão.

c) Adesão: é o resultado da ação de forças que se opõem a separação das moléculas que pertencem a substratos diferentes, em razão da atração entre duas substâncias diferentes resultando de uma força intermolecular entre as substâncias. Esta adesão é geralmente causada por interações moleculares entre o substrato e o adesivo e não necessariamente ligações químicas. As ligações químicas ocorrem por sua vez por poucos instantes.

d) Força adesiva: força responsável por promover a união dos substratos ao longo de suas superfícies de contato.

e) Aderência: é o resultado da ação de forças que se opõem a separação de substratos diferentes.

f) Coesão: diferente da adesão que envolve forças entre o adesivo e o substrato, a coesão ocorre dentro da estrutura do material e se refere à união das moléculas de uma mesma substância, definindo-se como a ação de forças que se opõem a separação das moléculas de um corpo homogêneo. A coesão é determinada por forças internas de um determinado material ou substância e é manifestada principalmente pelas ligações químicas entre as moléculas.

g) Força coesiva: força de resistência interna do material (substratos e adesivo) ao escoamento.

h) Coerência: resultado da ação de forças que se opõem à separação de moléculas de uma substância heterogênea.

i) Junta adesiva ou ligação adesiva: junta constituída por meio do emprego de um adesivo.

A Ilustração 2 apresenta um diagrama representativo referente aos fenômenos da adesão, aderência, coesão e coerência. 
Ilustração 2 - Diagrama representativo: adesão, aderência, coesão e coerência
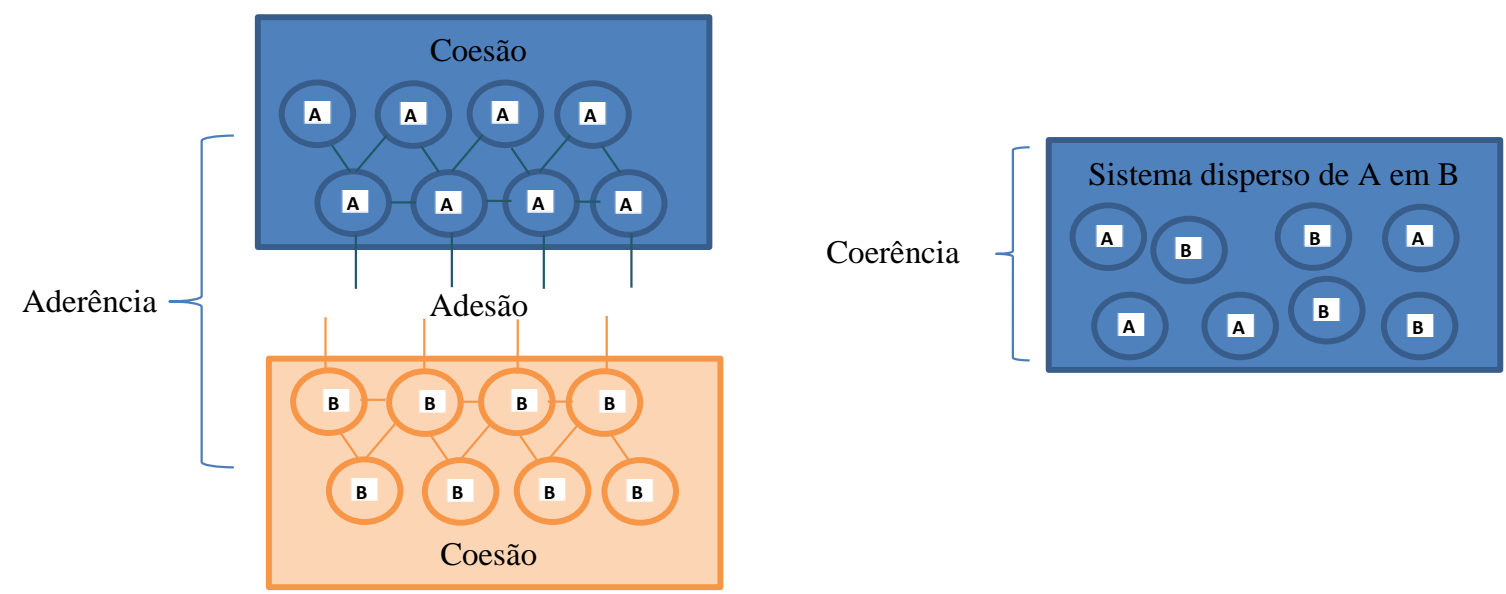

Fonte: adaptado de LIESA; BILURBINA, 1990.

Substratos ou aderentes: materiais sólidos, que não o adesivo, presentes em uma junta adesiva, ou seja, é o material a ser colado, local onde o adesivo será aplicado.

Interfase: espaço tridimensional de material entre o adesivo e o substrato. É uma região fina entre os pontos de contato entre o adesivo e o substrato. Esta região tem diferentes características físicas e químicas e essas características é que influenciam na qualidade da adesão. A estrutura, composição e as propriedades macroscópicas do adesivo e do substrato podem mudar na região da interfase, como por exemplo, no caso de difusão de pequenos componentes na região de interfase.

Interface: é uma região separada da interfase, porém está contida nela. É um plano bidimensional de contato entre a superfície do material e a superfície do outro. A interface é utilizada para descrever as energias de superfície.

Base: produto auxiliar empregado para regular a penetração do adesivo no substrato.

Primers: promotores de adesão entre substratos de colagem difícil, uma vez que apresentam afinidade química com o substrato e o adesivo, promovendo uma ponte entre ambos (FOTEA; D’SILVA, 2005).

Na Ilustração 3 apresenta-se um esquema representativo de uma junta adesiva com seus principais elementos, exemplificando alguns termos que foram elencados previamente. 
Ilustração 3 - Esquema de uma junta adesiva

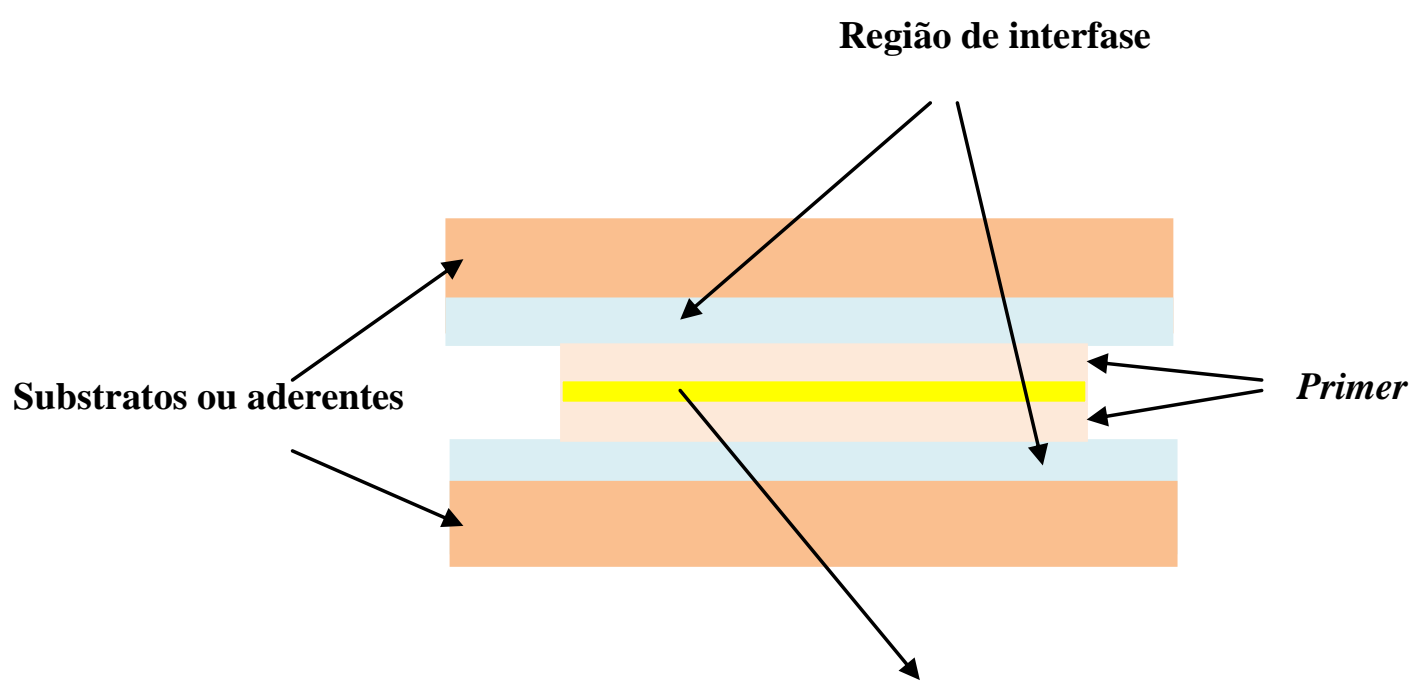

Adesivo ou selante

Reticulante ou catalisado: componente adicionado ao adesivo para promover aceleração da cristalização do mesmo, melhorando sua resistência a graxas e óleos, além de promover aumento da resistência ao calor da junta adesiva (MARTíNEZ GARCIA; SÁNCHES-RECHE; MARTÍN-MARTÍNEZ, 2005).

Reativação: processo que tem por finalidade recuperar a aderência das películas de adesivo, mediante a aplicação de calor ou solvente.

Tack: propriedade do adesivo que o permite molhar o substrato imediatamente, na ausência ou na presença de pressão pequena aplicada sobre o mesmo, resultando no desenvolvimento rápido de força elevada coesiva do adesivo (POCIUS, 2002).

Tackifier: substância adicionada à resina base de adesivos elastoméricos, a fim de melhorar as propriedades de tack dos mesmos. Tais substâncias são normalmente constituídas de resinas fenólicas e atuam como antiplastificantes, aumentando a temperatura de transição vítrea (Tg) e a resistência térmica do adesivo resultante (POCIUS, 2002).

Temperatura de amolecimento VICAT (ASTM D1525): temperatura na qual uma agulha penetra o corpo de prova de $1 \mathrm{~mm}$ de profundidade, sob carga de 10 ou $50 \mathrm{~N}$.

Pot life: tempo útil de trabalho do adesivo.

Tato: capacidade de adesão sob a ação de pouca pressão.

Tato inicial: tato apresentado imediatamente após a aplicação do adesivo.

Tração: esforço perpendicular ao plano da junta, aplicado uniformemente em toda a área dos substratos.

Cisalhamento: esforço paralelo ao plano da junta. 
Clivagem: esforço perpendicular ao plano da junta, aplicado na extremidade dos substratos (rígidos).

Despelamento: esforço perpendicular ao plano da junta, aplicado na extremidade do substrato (flexível).

Hot melt: adesivo $100 \%$ sólido, muito versátil, utilizado também como selante, possui estabilidade térmica e resistência ao envelhecimento, possuindo contração mínima. (GALEMBECK; GANDUR, 1995).

\subsection{TEORIAS DA ADESÃO}

Nesta seção, serão apresentadas várias teorias da adesão que vem sendo testadas ao longo do tempo. São várias teorias, pois não se tem uma teoria universal de adesão que consiga explicar um modelo único de interação entre adesivo e aderente satisfatório. Ao invés disso, várias teorias pretendem racionalizar as observações a respeito das uniões adesivas.

\subsubsection{Teoria de Interligação Mecânica}

O princípio envolvido nesta teoria é antigo e intuitivo e está relacionado ao fato de que o aumento da irregularidade da superfície do substrato promove uma ancoragem mecânica melhor do adesivo neste, além de criar uma superfície limpa, isenta de substâncias de energia superficial baixa e de também aumentar a área superficial a ser colada. Tal processo de aumento da irregularidade pode ser obtido por métodos físicos (lixando ou jateando a superfície, por exemplo), métodos químicos desde simples até bastante sofisticados (limpeza por solvente, lavagem com detergente, limpeza com ácidos ou álcalis como tratamento com radiação ultravioleta, ou ultrassom) e métodos energéticos (plasma, descarga corona e laser).

A Ilustração 4 representa pelas hastes azuis os pontos de ancoragem entre o adesivo e substrato. 
Ilustração 4 - Ancoragem do adesivo no substrato (hastes azuis)

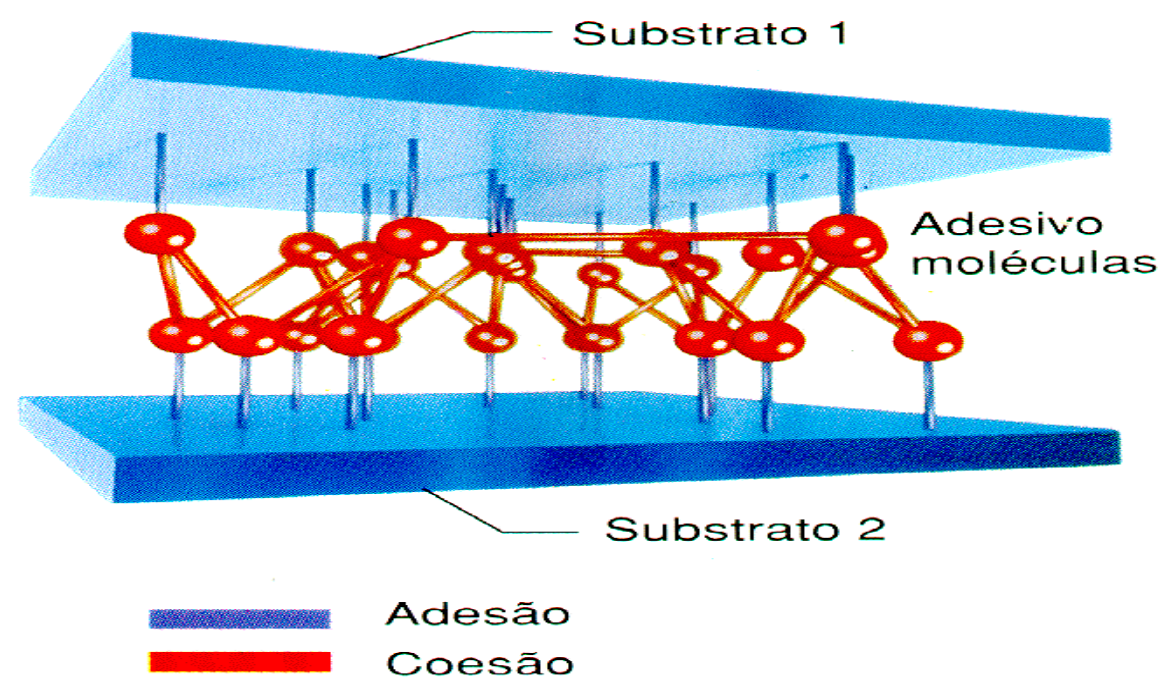

FONTE: FLEICHMANN et al, 1997

\subsubsection{Teoria de Adsorção}

Essa teoria propõe que, uma vez que haja proximidade suficiente entre as moléculas superficiais dos substratos e adesivo, esses materiais tenderão a se unir, uma vez que forças interfaciais estarão atuando sobre os mesmos.

Tais forças de atração interfacial podem ser de vários tipos, sendo as mais comuns as forças físicas de van der Waals ou ligações secundárias, e as forças químicas, normalmente covalentes, denominadas de ligações primárias. No caso das forças físicas de interação, é necessário que haja contato íntimo entre as moléculas do substrato e adesivo. Em contrapartida, as forças químicas de interação são consideravelmente mais intensas do que as anteriores e geram ligações adesivas muito mais efetivas.

O contato físico entre o adesivo e o substrato é um dos aspectos fundamentais para obter-se uma união satisfatória, e um conceito muito importante para se compreender as teorias de adesão é o conceito da energia superficial.

A energia superficial está relacionada ao estado dos elétrons superficiais, ou seja, se eles possuem energia de excitação alta ou baixa. Este estado energético permite definir superfícies polares e não polares. As superfícies nas quais os elétrons têm energia superficial baixa, energia de excitação baixa são denominadas superfícies não polares, e, aquelas com energia superficial e energia de excitação alta são superfícies polares. 
A molhabilidade ou umectação pode ser definida como sendo a medida do ângulo de contato entre o adesivo e o aderente. Ela é representada pela equação de Young (equação 1), a qual apresenta o ângulo de contato de equilíbrio, representado por $\theta$, realizada pelo componente de molhabilidade sobre o substrato em relação a tensão interfacial.

$\gamma_{\mathrm{LV}} \cdot \cos \theta=\gamma_{\mathrm{SV}}-\gamma_{\mathrm{SL}}$

em que:

$\gamma_{\mathrm{LV}}=$ tensão superficial do material fluido em equilíbrio com seu vapor

$\gamma_{\mathrm{SV}}=$ tensão interfacial do material sólido com o vapor de fluido

$\gamma_{\mathrm{SL}}=$ tensão interfacial entre o material sólido e o líquido

A molhabilidade é favorecida quando a tensão superficial ou energia crítica de superfície, $\gamma_{\mathrm{C}}$, é maior do que a tensão de superfície do líquido. Polímeros com energia de superfície baixa molham facilmente substâncias com energia de superfície alta como metais.

Coberturas poliméricas e substratos poliméricos possuem energia de superfície baixa e são dificilmente molhados por outros materiais, necessitando muitas vezes de uma preparação especial para que haja interação entre os materiais.

Resumindo:

Para que haja molhabilidade boa: $\gamma_{\text {adesivo }}<<\gamma_{\text {C substrato }}$

Para não haver molhabilidade boa: $\gamma_{\text {adesivo }}>\gamma_{C}$ substrato

Assim, os líquidos só molharão, ou seja, se espalharão e produzirão um contato satisfatório, com sólidos cuja energia superficial seja superior a sua própria. Citando um exemplo, a água molha bem uma superfície metálica, porém não tem o mesmo comportamento quando colocada sobre uma superfície de polietileno.

Se uma gota de adesivo é colocada sobre uma superfície limpa e plana, pode-se observar em um espaço de tempo curto, que a superfície da gota do adesivo, forma um ângulo em relação à superfície do substrato. Este ângulo é denominado ângulo de contato e depende da afinidade entre o adesivo e o substrato, de modo que se a gota de adesivo se estende em uma película formando com a superfície do substrato um ângulo de zero grau, diz-se que este adesivo molhou bem o sólido e está em contato íntimo com ele. Ao contrário, se a gota não se estende sobre a superfície, ou inclusive se retrai, elevando o ângulo com a superfície, isso indica que há pouca ou nenhuma afinidade com o substrato. Quando a molhabilidade é eficiente, a probabilidade do sucesso da união é esperada. 
Quando a superfície do substrato e o adesivo não têm afinidade, pode-se modificar a estrutura superficial para incrementar a polaridade da mesma, até o ponto em que ela se torne umectável pelo adesivo.

Na Ilustração 5a apresenta-se um esquema elucidativo sobre o conceito de ângulo de contato, e na Ilustração 5b representam-se superfícies polares e apolares, juntamente com os conceitos de molhabilidade ou umectação.

Ilustração 5a - Ângulo de contato

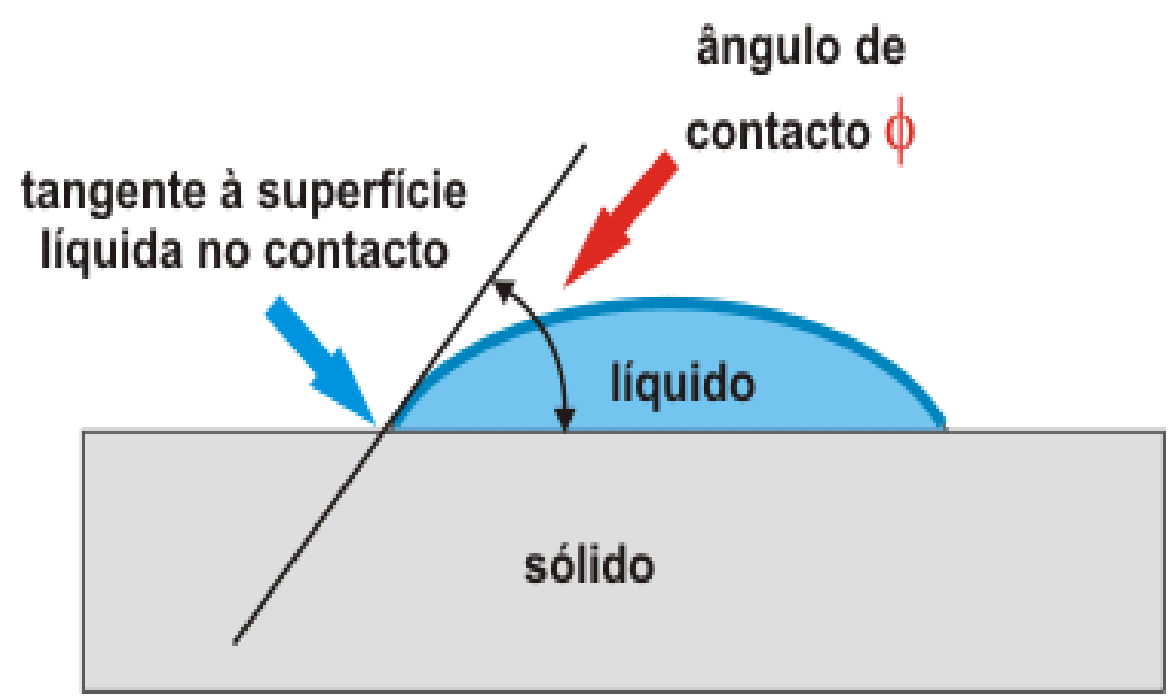

Fonte: Adaptado de FLEISCHMANN et al, (1997)

Ilustração 5b - Superfícies polares e apolares, molhabilidade ou umectação
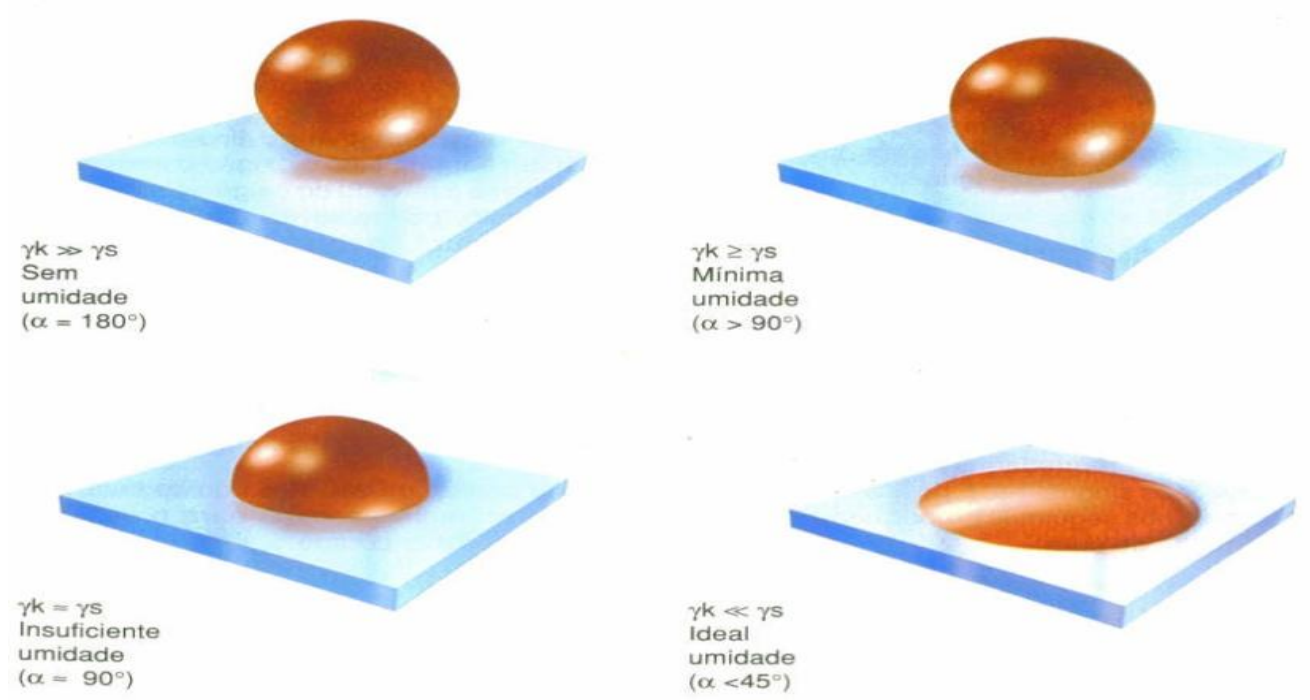
Com base nesta teoria, as indústrias de adesivos têm empenhado esforços no desenvolvimento de substâncias poliméricas denominadas primers.

\subsubsection{Teoria da Difusão}

Quando um adesivo contém um solvente, este pode difundir-se na superfície do aderente (substrato) com modificações das moléculas. Esta teoria é somente aplicada aos polímeros nos quais um movimento de moléculas longas pode ocorrer.

Enquanto esta teoria aplica-se para casos de auto adesão, não explica uma adesão polímero-polímero. A massa molar alta de polímeros termoplásticos geralmente apresentam índice alto de fluidez e não há facilidade para difusão, dentro da escala de tempo desejada, na maioria das operações de adesão.

\subsubsection{Teoria das camadas de bordas fracas}

Muitas vezes, na falha de um adesivo, a ruptura não se dá na interface, mas em uma região no interior do substrato ou adesivo, bem próxima à interface. Segundo esta teoria, a adesão fraca em uma junta adesiva pode ser ocasionada pela presença na interface de substâncias de massa molar baixa, líquido não polimerizado do adesivo, ar aprisionado, umidade ou impurezas. Neste caso, como o contaminante é considerado coesivamente mais fraco do que o adesivo ou substrato, a falha da junta deve ocorrer dentro da camada do contaminante.

\subsubsection{Teoria da tensão crítica superficial dos substratos}

Constitui a teoria mais empregada nos diversos estudos relacionados ao desempenho de adesivos em determinados substratos. Tal teoria prega que, para que haja molhabilidade de um adesivo qualquer em um determinado substrato sólido, é necessário que a energia superficial do adesivo selecionado seja inferior à energia superficial do substrato. Cabe ressaltar, entretanto, que a molhabilidade é uma condição necessária, mas não suficiente para que haja adesão adequada entre dois substratos, uma vez que o desempenho mecânico bom de uma junta adesiva qualquer depende também dos seguintes fatores: compatibilidade química entre os substratos e adesivos, ancoragem mecânica do adesivo no substrato, remoção de impurezas das superfícies dos substratos, dentre outros. (PETRIE, 2007). 


\subsection{CARACTERÍSTICAS DOS ADESIVOS}

As principais características responsáveis pelas diferenças de propriedades e desempenho entre os diversos tipos de adesivos são:

a) Viscosidade: constitui um parâmetro de suma importância e seu controle é fundamental para que se obtenha adequada resistência da junta adesiva. Isto porque se o adesivo possuir viscosidade muito baixa, ele escoará demasiadamente para o interior dos substratos, especialmente se os mesmos possuírem elevada porosidade, resultando em uma película de filme adesivo de espessura insuficiente para que haja aderência boa entre os materiais a serem unidos. Ao contrário, no caso de um adesivo que possua viscosidade excessivamente alta, o mesmo não será capaz de penetrar completamente nos poros dos substratos, resultando em espaços vazios na interface. A presença de tais espaços vazios, em conjunto com a possível presença de impurezas de energia coesiva baixa nas superfícies dos materiais a serem unidos, ocasionará significativa perda de resistência da junta adesiva (POCIUS, 2002).

b) Teor de Sólidos: corresponde à parte do filme adesivo que permanece sobre a superfície dos substratos, após a evaporação dos solventes. A importância desse parâmetro deve-se ao fato destes sólidos serem, na realidade, os componentes ativos responsáveis pela colagem dos substratos (ISO 472, 1999).

c) Tempo de secagem: intervalo de tempo decorrido entre o instante em que o adesivo foi aplicado sobre o substrato e o instante em que o mesmo teve todo o seu solvente ou água, evaporados (ISO 472, 1999).

d) Tempo aberto: corresponde ao intervalo máximo de tempo que um filme adesivo pode permanecer seco, ao ar, e ainda possuir capacidade auto aderente ("tack"), sob determinadas condições de temperatura e umidade relativa do ar (ISO 472, 1999).

A sequência dos diversos intervalos de tempo envolvidos em um processo de colagem pode ser visualizada, de forma esquemática, na Ilustração 6 .

Ilustração 6 - Tempos envolvidos em um processo de colagem

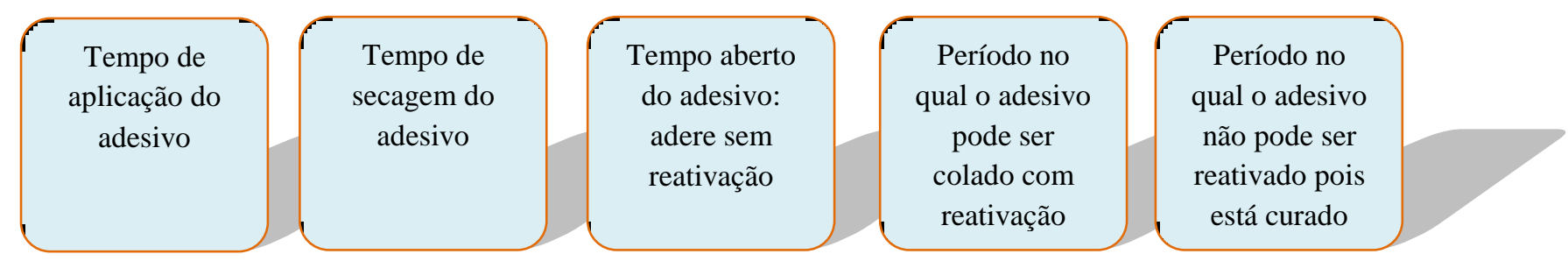




\subsection{CLASSIFICAÇÃO DOS ADESIVOS}

Os adesivos podem ser classificados segundo diversos critérios, a saber: origem dos componentes primários, temperatura de cura, resistência à umidade, composição química, forma física, dentre outros. Neste trabalho, a classificação será feita a partir da composição química e forma física dos adesivos (BORRACHA ATUAL, 2007 e CAMPOS; LAHR, 2004). No que se refere ao primeiro destes dois critérios, pode-se, inicialmente, dividir os adesivos em dois grandes grupos, conforme discriminado a seguir:

a) Adesivos inorgânicos: dentre os adesivos inorgânicos mais comuns podem ser destacados aqueles à base de silicatos, possuindo, os mesmos, ligações químicas intra e intermoleculares com elevada resistência mecânica.

b) Adesivos orgânicos: em geral, divide-se ainda tal categoria de adesivos em dois sub-grupos: sintéticos e naturais. Os adesivos orgânicos sintéticos são os mais empregados pelas indústrias calçadista, automobilística, madeireira, dentre outros setores industriais, em razão da sua maior resistência à água e, por apresentarem resistência elevada à ação de microrganismos. Adicionalmente, os adesivos sintéticos são também classificados em termofixos e termoplásticos, sendo os primeiros aqueles que endurecem por meio de reações químicas, ativadas por ação do calor ou de catalisadores. Já os adesivos termoplásticos apresentam como característica principal a sua cura reversível, sendo os mesmos, normalmente, aplicados em emulsão ou no estado fundido. Neste último caso, recebem a denominação especial de adesivos hot-melt. (POCIUS, 2002).

O outro critério comumente utilizado pelas indústrias para classificar os diversos tipos de adesivos, diz respeito à forma física dos mesmos, apresentadas a seguir :

a) Filme adesivo: contém todos os agentes de cura necessários para que se obtenha uma resistência eficaz da ligação adesiva; necessita de calor para que a cura se processe e requer manuseio especializado para gerar a cura do adesivo e a ligação propriamente dita. Os filmes adesivos devem ser estocados a temperaturas baixas e são bastante utilizados nas indústrias eletrônica e aeroespacial.

b) Adesivos em pasta: podem ser materiais compostos por uma ou duas partes e possuem forma física de pasta ou líquido viscoso. As pastas de adesivos compostos por uma única parte são vendidas completamente formuladas e contendo todos os materiais necessários para que haja a cura do polímero (adesivo). É preciso adicionar calor ou outra forma de energia para que a cura possa se processar. Esse tipo de material encontra seu campo de aplicação maior na indústria automotiva. As pastas de adesivos em duas partes, por sua vez, 
são formuladas de modo que os agentes de cura compõem uma das partes e as resinas a serem reticuladas a outra parte. Esses materiais são estocáveis a temperatura ambiente e a cura é concretizada quando as duas partes são misturadas.

c) Líquidos adesivos: esses adesivos são estáveis a temperatura ambiente, quando mantidos no interior de suas embalagens. Tais adesivos são curados pela umidade do ambiente ou pela presença de ar atmosférico. Versões mais sofisticadas de adesivos líquidos são utilizadas na indústria eletrônica na forma de uma combinação primer/líquido. Neste caso, o primer contém o agente de cura e os líquidos constituem as resinas curáveis. A mistura dos dois, portanto, resulta na cura do adesivo.

d) Adesivos em solução (água ou solvente): muito empregados para unir madeiras, borrachas e couro, sendo os mesmos habitualmente empregados pelas indústrias calçadistas, para montagem e colagem de diversos tipos de solados a cabedais de couro. À semelhança dos adesivos em pasta e dos líquidos, podem ser encontrados em uma ou duas partes. Atualmente, entretanto, em razão de prejuízos ecológicos ocasionados pelos solventes orgânicos, grandes esforços têm sido despendidos pelas diversas empresas para substituí-los por adesivos em solução aquosa.

e) Adesivo de contato: adesivos derivados de matérias primas de policloropreno, resinas fenólicas, resinas derivadas de breu, que possuem tempo em aberto proporcional taxa de colagem, possuindo adesão inicial eficiente, de aplicação fácil, custo baixo e resistência alta. São flexíveis, possuem teor de sólidos entre 12 e $28 \%$ quando na base solvente. São muito utilizados em indústria moveleira e tapeçaria. É um tipo de adesivo que deve ser aplicado em ambos os substratos que devem ser unidos e deve-se esperar para o solvente evaporar, e então, os substratos são colocados em contato (GALEMBECK; GANDUR, 1995). 


\section{ESTADO DA ARTE: ADESIVOS DE POLICLOROPRENO}

O objeto de estudo desta tese, como citado anteriormente, é o adesivo de policloropreno, que é um tipo de adesivo termoplástico de contato. É uma substância cujas propriedades físicas são semelhantes à da borracha natural, porém mais forte, e possui resistência alta à temperatura. $\mathrm{O}$ adesivo de neopreno, ou policloropreno, é muito utilizado para a colagem de superfícies metálicas, e, filmes curados desse material são mais rígidos que outros adesivos elastoméricos. Também apresentam resistência boa à água, névoa salina, produtos químicos e biodegradação.

Além da excelência na união entre substratos metálicos, os adesivos de policloropreno são eficientes em outros universos, como a indústria moveleira e calçadista.

\subsection{POLICLOROPRENO}

O Policloropreno se tornou conhecido genericamente por elastômero de policloropreno.

Quando o policloropreno é dissolvido em um solvente orgânico, pode ser fornecido como adesivo de contato, podendo ser aplicado por pincel ou utilizando-se o método spray, ou ainda pode ser extrudado na forma de mastic, denominação utilizada para se referir a um material com propriedades não secativas, e utilizado com a finalidade de calafetação. Estes adesivos possuem um conjunto de propriedades físico químicas e reológicas que dependem muito de sua estrutura particular (BRANLARD; PARISOT).

O policloropreno é um homopolímero de cloro-2-1,3-butadieno, estrutura derivada do isopreno, tendo o grupamento metil substituído por um átomo de cloro, apresentado na Ilustração 7.

Ilustração 7 - Esquema representativo das fórmulas estruturais do isopreno e cloropreno<smiles>C=CC(=C)C</smiles>

Metil-2 butadieno ou isopreno<smiles>C=CC(=C)Cl</smiles>

cloro-2 butadieno ou cloropreno 
A substituição de um grupo metil nucleofílico por um átomo de cloro, fortemente eletrofílico, resulta nas seguintes consequências:

a) Presença de um teor de cloro de aproximadamente $40 \%$, o que confere ao policloropreno uma resistência intrínseca ao fogo, muito superior a outros elastômeros halogenados.

b) Desativação das duplas ligações, o que explica as propriedades adequadas contra o envelhecimento pela ação do oxigênio e ozônio, que atuam sobre as duplas ligações.

c) Polaridade da ligação, que resulta em:

- resistência química aos solventes não polares, parafínicos e naftênicos e, por outro lado, solubilidade eficiente nos solventes polares aromáticos ou clorados;

- possibilidade de desenvolver forças de aderência elevadas sobre variedade grande de suportes polares ou polarizáveis, o que determina sua aplicação em adesivos.

A estrutura molecular dos policloroprenos é essencialmente determinada pela temperatura de polimerização e pelos agentes modificantes utilizados no decorrer da polimerização.

A temperatura de polimerização é que determina as diferentes configurações possíveis para o cloropreno, bem como seus respectivos teores. Certas configurações possuem importante influência sobre a cristalização e vulcanização dos policloroprenos. A ilustração 8 apresenta as configurações de cloropreno formados em função das energias de ativação, no que diz respeito a sua natureza e proporção.

Ilustração 8 - Configurações do cloropreno

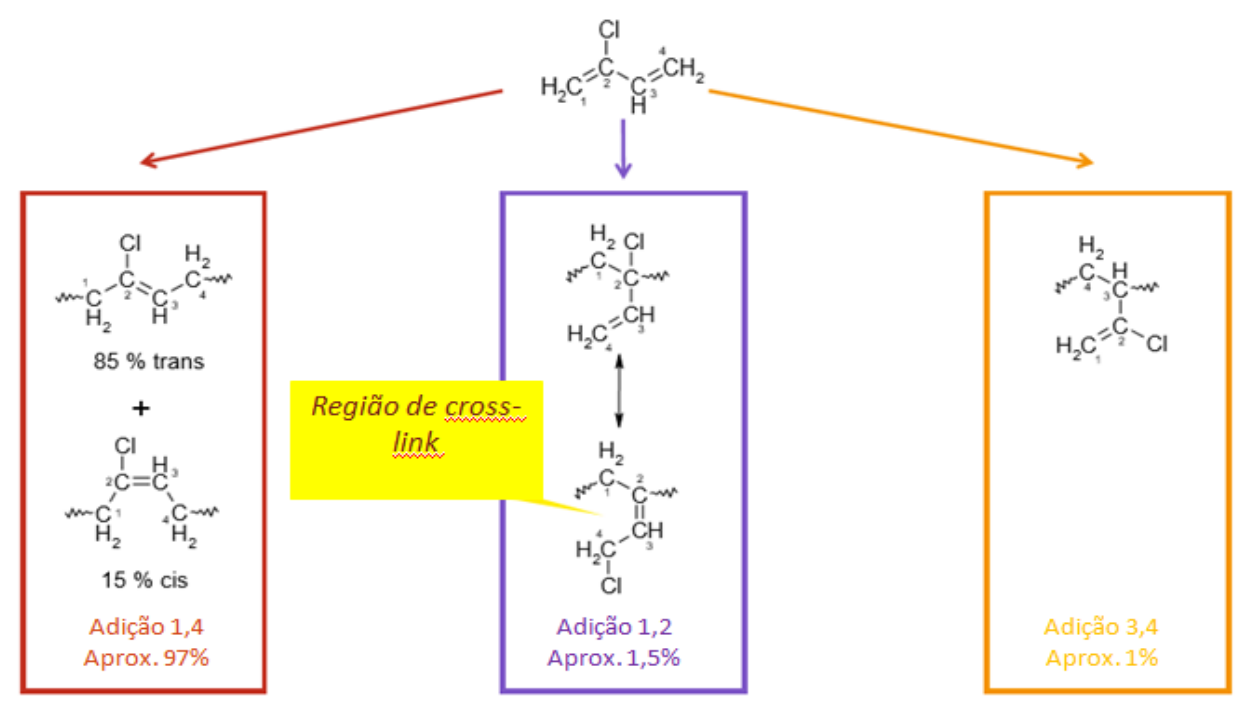


A variação dos teores das configurações ou encadeiamentos em função da temperatura de polimerização é apresentada na ilustração 9.

Ilustração 9 - Diferentes configurações de cloropreno em função da temperatura de polimerização

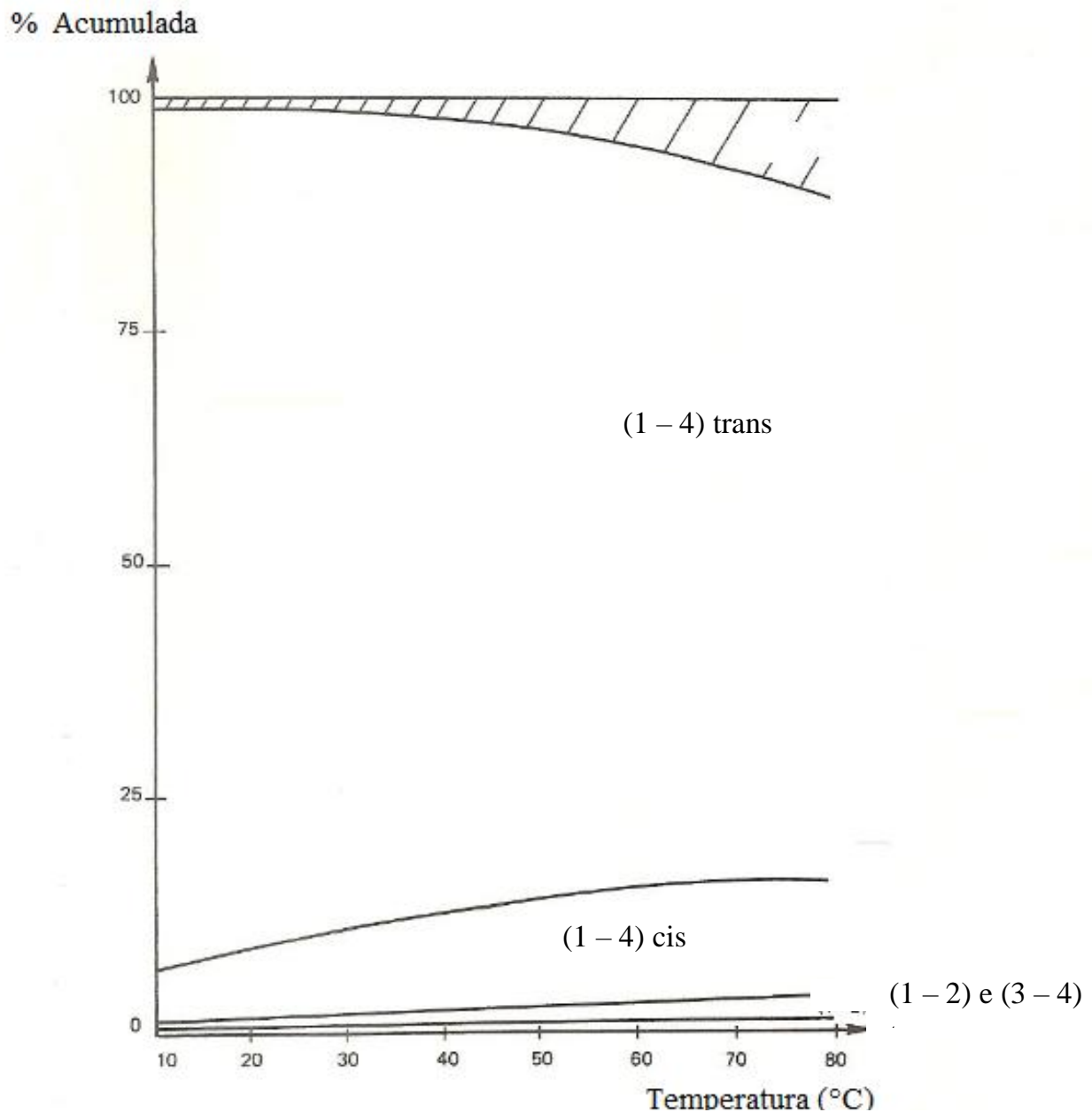

Fonte: BRANLARD; PARISOT, 198-?

Pode- se observar que a configuração 1 - 4 trans é produzido em maior quantidade durante o processo de polimerização, e cada motivo apresentado na ilustração 9 possui um papel específico no polímero formado, sendo cada um deles explicado a seguir:

a) Encadeiamento $(\mathbf{1}$ - 4) trans: o teor elevado destas configurações e a estereoregulação das cadeias poliméricas resulta em propriedades mecânicas excelentes e tendência a cristalização. 
b) Encadeiamento $(\mathbf{1}$ - 4) cis: estas estruturas se inserem estatisticamente nas cadeias, desorganizando sua estereoregularidade e consequentemente diminuem a cristalinidade do polímero.

c) Encadeiamento $(\mathbf{1}$ - 2) e $\mathbf{( 3 - 4 )}$ : o átomo de cloro para o (1 - 2) e aquele de hidrogênio para o $(3$ - 4) encontram-se em posição alilílica em relação a dupla ligação o que lhes confere a particularidade de serem lábeis. São eles que vão contribuir para a vulcanização do policloropreno (BRANLARD; PARISOT, 198-?).

\subsection{SÍNTESE DE POLICLOROPRENO}

O polímero em questão é sintetizado pelo processo de poliadição, a partir de monômeros de cloropreno. Os polímeros de adição (poliadição) são aqueles em que, durante a sua formação, isto é, reação entre os monômeros, não evidenciam perda de massa na forma de compostos de massa molar baixa. Assumindo-se a conversão total, a massa final do polímero formado é igual ao peso de monômeros adicionados. Normalmente, estes polímeros tem cadeia carbônica, como é o caso do policloropreno (CANEVAROLO JÚNIOR, 2013).

\subsection{ADESIVOS DE POLICLOROPRENO}

São adesivos de contato, que, quando em solução solvente, apresentam um conjunto de propriedades que nenhum outro adesivo possui, que são, a aderência sobre grande variedades de substratos, pega imediata e desenvolvimento de coesão do filme após união dos substratos (BRANLARD; PARISOT, 198-?).

\subsubsection{Adesivo de policloropreno base solvente}

Levando em conta que um dos universos a serem estudados nesta pesquisa foi um adesivo de policloropreno base solvente, inicia-se aqui uma explanação a respeito da sua produção e aplicação. Cabe salientar que o adesivo base solvente que foi utilizado nesta pesquisa não utiliza como solvente o tolueno.

Embora os adesivos de policloropreno base solvente estejam sofrendo modificações na sua formulação para atender regulamentações ambientais e de saúde, principalmente no que diz respeito à substituição do tolueno, estes ainda são produzidos utilizando outros solventes, 
tais como o acetato de etila, a acetona e o metil-etil-cetona (MEK), normalmente em combinações entre si, havendo ainda outros, como o acetato de sec-butila e os acetatos de isopentila, isopentanol e isobutanol (obtidos com a fermentação de açúcares) e álcoois graxos etoxilados.

A preocupação com o uso indiscriminado e perigoso à saúde, a maior parte das vezes por menores abandonados, fez a Agência Nacional de Vigilância Sanitária (ANVISA) criar a Resolução RDC 345, de dezembro de 2005, a partir da qual apenas maiores de idade, com apresentação de carteira de identidade e preenchimento de guia, podem adquirir as colas.

Embora com a resolução da ANVISA tenha havido um pouco mais de controle, a verdade é que a medida parece não ter sido muito eficaz. Tanto foi assim que as colas ainda são a terceira droga mais utilizada no Brasil. E isso por um motivo capital: não é difícil imaginar que muitos menores utilizem terceiros para comprar as colas, criando um mercado paralelo, ou que muitos apresentem documentos falsos de identidade para a aquisição. A simples existência delas nas prateleiras de lojas já cria a tentação e a possibilidade de uso irregular e maléfico à crianças e adolescentes espalhados pelas cidades.

Essa constatação está fazendo a ANVISA rever sua posição e é muito provável que em breve os solventes com tolueno (toluol) sejam banidos definitivamente dos adesivos. Foi criado um grupo de trabalho e há informações sérias no mercado de que o desejo da agência é o de seguir o caminho de países europeus, como a Alemanha, que proíbe esses solventes em produtos de varejo e só os permite para uso industrial, ou até mesmo de lugares mais próximos, como o Chile, que também adotou a proibição. No Brasil, algumas empresas já efetuaram a mudança total dos solventes em seus adesivos de contato.

Tendo feito esta abordagem que justifica a substituição do tolueno nas formulações do adesivo de policloropreno base solvente, serão apresentados os processos usuais de produção dos adesivos base solvente na condição em que eles possam ser produzidos.

Existem basicamente três processos industriais habitualmente empregados na fabricação dos adesivos de policloropreno base solvente, sendo estes processos denominados de: técnica clássica, método da dissolução direta e método combinado.

A técnica clássica é um método que consiste em mastigar a borracha em um misturador interno ou de cilindros e durante esta operação adicionar ao polímero agentes protetores, óxidos metálicos, tackifier e cargas. Em seguida a mistura é cortada em pedaços ou grânulos, sendo os mesmos posteriormente juntados à resina e ao sistema solvente capaz de dissolvê-los. Este método apresenta as seguintes vantagens: 
a) Controle fácil da viscosidade final do adesivo, uma vez que o tempo dispensado na mastigação da borracha é inversamente proporcional à viscosidade final do adesivo. Tal fenômeno é resultante do trabalho mecânico do misturador sobre a cadeia polimérica.

b) Comportamento reológico do adesivo eficiente, pois a operação de mastigação reduz o tamanho das cadeias macromoleculares longas, quebra suas ramificações e destrói eventuais microgéis, ou seja, reduz-se a viscosidade da borracha, determinando a obtenção de um produto de processabilidade desejada, com bom espalhamento e tamanho de partícula reduzido.

c) Diminuição da sedimentação de óxidos metálicos e cargas, já que a mastigação propicia maior interação físico química destes sólidos com a borracha, dificultando a desagregação destes do adesivo e se evidenciem como resíduo de fundo.

d) Eliminação de microgel e água que possam ter se formado durante estocagem inadequada ou por tempo exagerado, uma vez que, o trabalho mecânico e o calor, que são desenvolvidos na mastigação tendem a eliminar esses inconvenientes.

Entretanto, a grande desvantagem deste método é a demanda por equipamentos de custo alto, além da reduzida produtividade, se comparada àquela proporcionada pelo método de dissolução direta.

Na dissolução direta por sua vez, não há mastigação prévia da borracha, pois este método consiste em adicionar de uma só vez, o sistema solvente, as resinas, os óxidos metálicos, os agentes protetores, o policloropreno e cargas minerais em um agitador adaptado para tal.

Este método apresenta como vantagem principal a eficiência econômica, pois requer um investimento reduzido em equipamentos, tem um consumo reduzido de energia, além de reduzir o tempo de processamento e mão de obra. Em contra partida, alguns inconvenientes podem ser destacados, como o fato de exigir do fabricante cuidados especiais com o tipo de estocagem do policloropreno, especialmente no que diz respeito aos fatores tempo e temperatura. Outros fatores derivados desse método são a dificuldade de controle da viscosidade final do produto, o risco de sedimentação dos óxidos metálicos e cargas minerais, pois a ausência da interação entre estes sólidos e a borracha, provenientes da não mastigação dos ingredientes, favorece a sedimentação dos mesmos; e finalmente, a processabilidade pode apresentar-se insuficiente, pelo fato de não se realizar a mastigação que é responsável pela redução do tamanho das cadeias macromoleculares e quebra de suas ramificações. A ausência desse processo pode vir a provocar efeitos indesejáveis após o produto acabado, como por 
exemplo, dificuldade no espalhamento do adesivo por pincel, espátula e pulverizadores, ocasionando má penetração do adesivo no substrato.

As vantagens econômicas importantes, associadas aos inconvenientes técnicos, decorrentes da utilização deste método, levaram os fabricantes de adesivos de policloropreno, a utilizar processos intermediários, objetivando, principalmente, à obtenção de produtos com comportamento reológico adequado.

Tal processo intermediário, também denominado de método combinado, consiste em produzir uma etapa de mastigação de uma parte da quantidade total da borracha a ser utilizada no adesivo (entre 10-50\%), juntamente com os óxidos metálicos e cargas. A mistura resultante é então dissolvida junto com o restante da borracha não mastigada. O processo descrito permite dessa forma, a minimização da sedimentação dos óxidos, melhor controle da viscosidade final e significativa melhora no comportamento reológico do adesivo. Todavia, como desvantagem, a exemplo do que ocorre na técnica clássica, tal processo requer investimento alto em equipamentos, uma vez que emprega os equipamentos de mastigação de borracha (BORRACHA ATUAL, 2007).

\subsubsection{Propriedades dos adesivos de policloropreno base solvente}

De uma maneira geral, e como já citado sucintamente anteriormente, o policloropreno caracteriza-se por ser um elastômero que apresenta como principais propriedades: resistência boa a óleo, calor, chama, oxigênio, ozônio e luz solar; resistência alta à tração e à abrasão, além de resiliência elevada, similar à borracha natural (MARTÍNEZ GARCIA; SÁNCHESRECHE; MARTÍN-MARTÍNEZ, 2005).

Complementarmente, além dessas propriedades, as quais são aplicáveis aos elastômeros de policloropreno de uma maneira genérica, os adesivos à base dessa substância em particular, possuem propriedades específicas que são responsáveis pela importância comercial grande deste produto, descritas a seguir:

a) Aderência sobre uma gama variada de substratos. A presença de um átomo de cloro na estrutura química do polímero lhe confere uma polaridade bastante acentuada, a qual permite o desenvolvimento de interações físicas fortes com os substratos e adesão melhor sobre os mesmos, sem que haja necessidade de aplicação prévia de substância halogenante na superfície destes substratos ;

b) "pega imediata" - Propriedade relacionada ao fato de o cloropreno "soldar-se" sobre si mesmo antes da sua cristalização mediante uma pequena pressão exercida; 
c) eficiência coesiva - resultante da facilidade de cristalização dos adesivos de policloropreno, estando esta propriedade diretamente relacionada à estereorregularidade da estrutura macromolecular do polímero. A coesão imediata aumenta progressivamente à temperatura ambiente, graças à cristalização, aumentando, igualmente, o módulo e rigidez do filme (MARTÍNEZ GARCIA; SÁNCHES-RECHE; MARTÍN-MARTÍNEZ, 2005);

d) resistência ao envelhecimento e agentes de degradação química - considerando-se uma formulação convencional contendo óxidos metálicos e agentes antioxidantes, o adesivo possui resistência adequada aos fatores de degradação (oxigênio, ozônio, calor), podendo conservar a coesão da colagem efetuada.

Porém, diversos fatores podem interferir no desempenho mecânico e na estabilidade térmica dos adesivos à base de policloropreno, fatores estes que devem ser controlados pelos fabricantes e usuários deste tipo de produto.

Várias pesquisas foram realizadas analisando possíveis matérias primas que podem ser incorporadas ao policloropreno, tendo como finalidade expressar as possíveis modificações que elas podem causar no desempenho dos adesivos, e os resultados dessas pesquisas são descritos a seguir:

a) Presença de cargas contendo negro de fumo - a presença de tal componente, em proporções entre 40-45 phr (per hundred resin), confere ao elastômero desempenho excelente no que se refere às suas propriedades mecânicas de resistência à tração, rasgamento e abrasão, além de resultar em alongamento menor na ruptura (MARTINS et al., 2002). Na Ilustração 10 apresenta-se o aumento da resistência à tração em relação ao alongamento para diversos teores de negro de fumo presentes em formulações de policloropreno. 
Ilustração 10 - Resistência à tração x alongamento para composições de elastômeros de policloropreno com negro de fumo

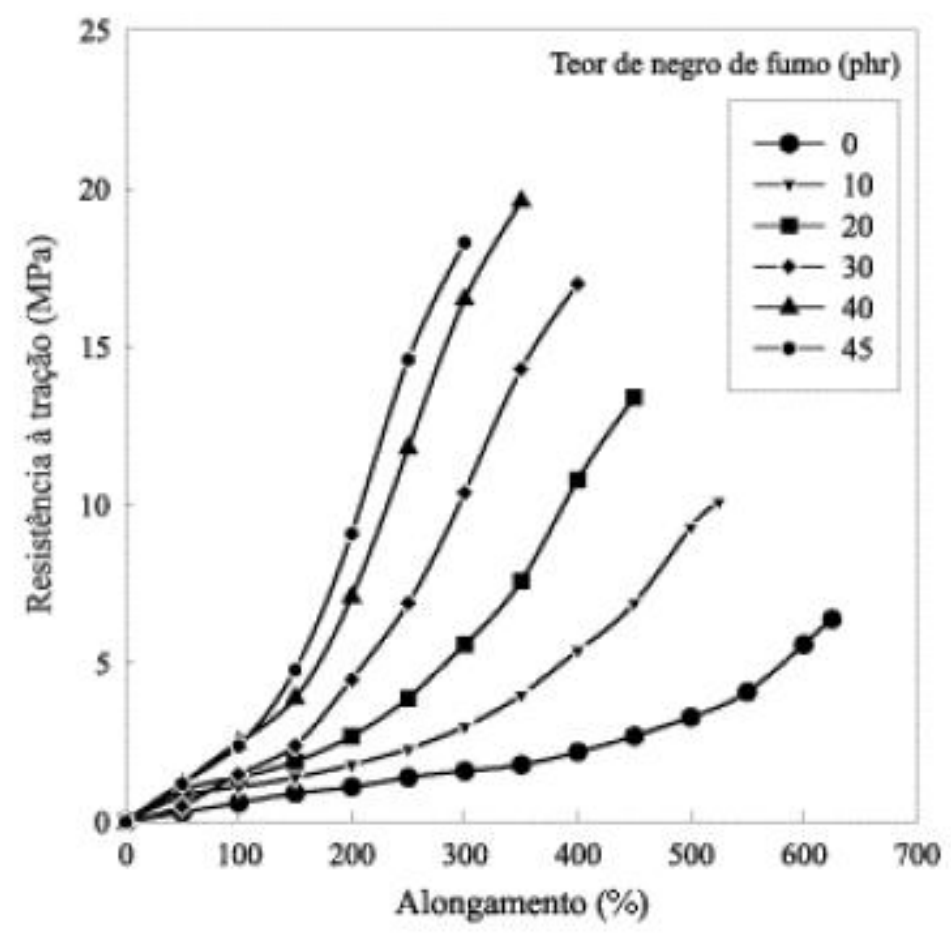

Fonte: MARTINS et al., 2002

Além da influência sobre as propriedades mecânicas, certas cargas exercem influência determinante sobre diversos parâmetros da vulcanização, promovendo, desta forma, diminuição no tempo de pré-cura (tempo necessário para que se inicie o processo de vulcanização) e sobre o índice de velocidade de cura (CRI), além de aumentar o tempo de vulcanização a $90 \%$ (tempo necessário para que se obtenha material $90 \%$ reticulado).

O grau de vulcanização interfere sobremaneira nas propriedades mecânicas e na estabilidade térmica de tais adesivos. A Ilustração 11 apresenta a influência do teor de carga sobre os diversos parâmetros de vulcanização. 
Ilustração 11- Parâmetros de vulcanização de composições de elastômeros de policloropreno com negro de fumo

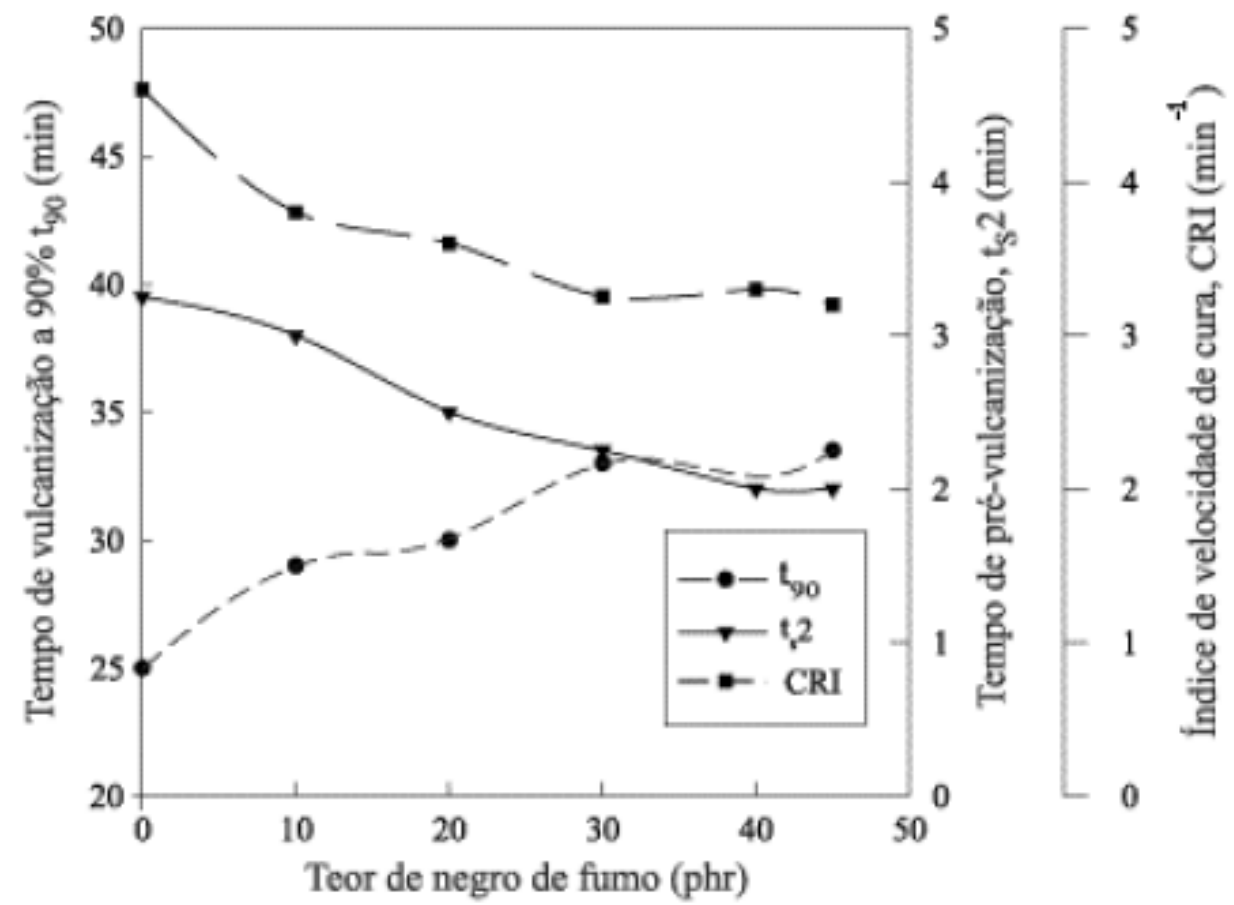

Fonte: MARTINS et al., 2002

b) Teor de poliisocianato misturado ao adesivo de policloropreno - Conforme dados de literatura, sabe-se que a adição de poliisocianato é essencial para a obtenção de adesivos de policloropreno capazes de gerar juntas adesivas com desempenho elevado nos ensaios de resistência ao descascamento. Foi ainda estabelecido (SKEIST, 1989) que tal adição favorece a cura destes adesivos em temperaturas baixas, além de melhorar a resistência dos mesmos à hidrólise (MARTÍNEZ GARCIA; SÁNCHES-RECHE; MARTÍN-MARTÍNEZ, 2005).

Outro assunto de importância, no que diz respeito ao comportamento do policloropreno, é a sua facilidade de degradação. ANACHKOV et al., (1993) reportaram que os elastômeros e, em especial, o policloropreno, são muito suscetíveis à degradação oxidativa. Entretanto, somente alguns anos depois, foi realizado um trabalho (DELOR et al., 1996) visando simular o efeito das irradiações fotolítica e térmica, sobre elastômeros de policloropreno, em condições moderadas que fossem representativas de um processo de envelhecimento natural dos mesmos. O referido trabalho avaliou ainda a influência do grau de reticulação e negro de fumo no processo de degradação oxidativa. Os autores empregaram dois tipos diferentes de elastômeros de policloropreno, denominados de CR1 e CR2, cuja 
diferença nas formulações está no teor de negro de fumo e óleos. Como condição de envelhecimento, para as amostras descritas, os autores utilizaram oxidação fotolítica ou térmica.

Inicialmente, como resultado dos dois processos de oxidação, os autores observaram amarelecimento rápido das duas amostras (CR1 e CR2) não reticuladas, tendo tal fato sido atribuído às reações de desidrocloração, com formação de estruturas altamente conjugadas na cadeia principal. O mecanismo completo de degradação proposto para o policloropreno pode ser visualizado na Ilustração 12.

Ilustração 12 - Esquema representativo do mecanismo de degradação do policloropreno

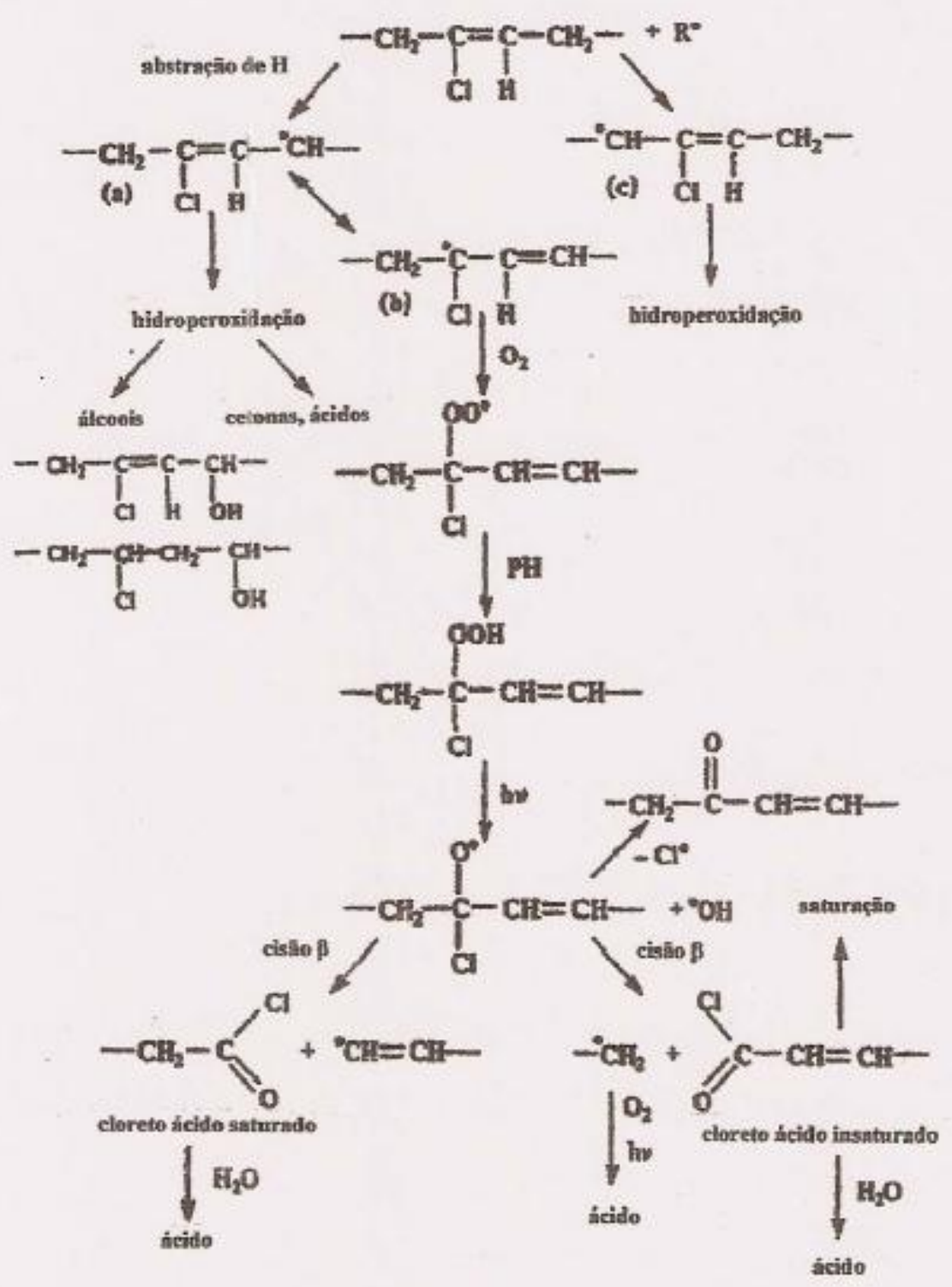


Da mesma forma, a amostra contendo negro de fumo (CR2) também apresenta taxas de oxidação menores, em virtude da referida carga, ter atuado nesse caso, como agente antioxidante (DELOR et al., 1996).

Portanto, o uso de agentes antioxidantes constitui normalmente, a solução adotada pelos formuladores de adesivos de policloropreno para evitar a desidrocloração e consequente insaturação e enrijecimento da cadeia carbônica principal. Da mesma forma, os tipos e os mecanismos de atuação das várias classes de agentes de proteção também são os mesmos já analisados anteriormente.

\subsubsection{Formulações típicas para o adesivo de policloropreno base solvente}

Atualmente, grande parte dos adesivos de contato, são formulados utilizando matrizes poliméricas com base em elastômeros de policloropreno. O desenvolvimento rápido de uma força de adesão juntamente com força final alta de adesão são características dos policloroprenos. Eles também possuem como características de interesse a autoadesão, resistência à tensão de cisalhamento e resistência a compostos químicos, em especial óleos.

Uma formulação típica de adesivo de contato base solvente de policloropreno é apresentado na Tabela 3.

Tabela 3 - Formulação inicial típica para um adesivo de contato base solvente de policloropreno

\begin{tabular}{lc}
\multicolumn{1}{c}{ Componentes } & Relação das partes por unidade de massa \\
\hline Etapa de moagem & 100 \\
Neopreno & 4 \\
Magnésio & 3 \\
Antioxidante, & 5 \\
Óxido de zinco & \\
Etapa de agitação & 111 \\
Material derivado da moagem & 45 \\
Resina terciária butil fenólica & qsp \\
Solventes $-15-30 \%$ de sólidos &
\end{tabular}


As principais propriedades de polímeros de policloropreno são a massa molar e a velocidade de cristalização. Aumentar a massa molar do polímero, resultará no aumento da viscosidade da solução, a força de adesão e a resistência ao calor. $\mathrm{O}$ aumento na velocidade de cristalização aumentará a velocidade de desenvolvimento da força de união, no entanto, a cristalinidade também poderá inibir o processo de difusão, que reduzirá o poder de autoadesão. Quanto maior o grau de cristalização, maior será a força de coesão do filme adesivo. Portanto, a seleção do grau de policloropreno será definida para que se tenha características e propriedades adequadas ao uso do adesivo, tendo em vista que o tempo em aberto, força de adesão, resistência ao calor, propriedades de aplicação e viscosidade do adesivo não sejam comprometidas.

Como já mencionado, o cloropreno é um homopolímero de 2-cloro-1,3-butadieno, normalmente preparado por processo de polimerização por emulsão. As formas do policloropreno obtidas nesse processo são altamente lineares e solúveis. Uma vez polimerizado, o policloropreno é coagulado por adição de um tipo específico de sal. Os elastômeros de policloropreno preparados para uma formulação de adesivo base solvente podem ser dissolvidos em uma variedade grande de solventes polares ou apolares. Essa possibilidade de solução possibilita uma variedade grande de viscosidades e tempos de secagem bem específicos para muitos tipos de substratos.

Outro fator de relevância na escolha de adesivos de contato base solvente é o tempo de evaporação do solvente. Geralmente, o solvente mais eficiente é aquele que possui volatilidade baixa, pois possui um tempo em aberto maior. Os exemplos de solventes utilizados são o hexano, tolueno, metil-etil-cetona, xileno e metil-isobutil-cetona, porém alguns, possuem regulamentação indicativa para sua substituição.

Até o presente momento apresentou-se uma formulação tradicional e teórica de adesivos de policloropreno base solvente. Porém esta família de adesivos também pode ser formulada com base aquosa, que é a família de adesivo que foi utilizada como objeto de estudo desta pesquisa, sendo este, obtido por meio de uma dispersão de elastômeros de policloropreno em água.

Segundo Petrie (2007), o resultado dessa formulação, isenta de solventes orgânicos, não apresenta as mesmas características e propriedades, descritas como eficientes, em comparação com um adesivo base solvente, que ainda é bastante presente no setor da indústria moveleira, ou seja, as forças de adesão são menores, demoram muito mais para secar, possuem força inicial baixa e apresentam dificuldade de colagem quando submetidos a pressões baixas, além de apresentarem resistência ao calor menor. 
Aparentemente, com este parecer, este tipo de adesivo base aquosa, não traz nenhum benefício no que diz respeito a sua eficiência de adesão, porém, evoluções na área de pesquisa e desenvolvimento têm trazido muitas contribuições para que o adesivo de contato de policloropreno base aquosa seja desejável no mercado.

Existem patentes, como por exemplo, a US 7659338 e a US 7354971, que demonstraram um avanço na formulação deste tipo de adesivo, e esta pesquisa utilizou uma matriz polimérica desenvolvida a partir de uma referência de formulação, com base nestas patentes, que prova a eficiência dessa tendência dos adesivos de policloropreno que será apresentada na próxima seção. (MUSCH et al., 2010; MUSCH; PANSKUS; STEINERT, 2008).

\subsubsection{Adesivo de contato de policloropreno base aquosa}

Os adesivos base aquosa, com matrizes poliméricas de policloropreno foram inseridos no mercado, mas algumas dificuldades técnicas interferiram na sua aceitação inicial. Atualmente, no que diz respeito a tecnologia de produção e aplicação desses adesivos, dados comprovados por estatísticas da ABIQUIM (2011), pode-se afirmar que o setor de adesivos e selantes passa por mudanças para melhor, em direção a soluções mais amigáveis ao meio ambiente e ao ser humano. No caso, a ascensão do consumo de adesivos de base água ou do uso dos chamados solventes "verdes", menos agressivos e tóxicos, embasa a constatação.

De acordo com os dados da ABIQUIM, divulgados pelo coordenador da comissão de adesivos e solventes, José Duarte Paes, a mudança é percebida por meio de levantamento realizado pela associação, o qual revela aumento de consumo da tecnologia base água em contraponto à queda nas de base solvente. "Em 2006, $27 \%$ dos adesivos eram com solvente, em 2011 caíram para 17\%. Os de base água representavam 46 \% e agora subiram para 57 \%”. Ainda em 2011, os hot-melts somaram 6,5\%; selantes, $16 \%$; e outros tipos, 3,5\% (epóxis, acrílicos, bicomponentes). Pode-se observar que estes dados diferem um pouco daqueles apresentados pelos participantes da LATINCOAT \& ADHESIVES (2012), porém a magnitude dos mesmos é comparável.

Analisando os dados da LATINCOAT \& ADHESIVES (2012) e da ABIQUIM (2011), evidencia-se, portanto, a diminuição do uso de solventes orgânicos e a busca por alternativas novas, como a substituição de ftalatos como plastificantes e a troca de catalisadores com metais pesados por outras substâncias químicas mais seguras. 
A substituição gradual do tolueno nas formulações dos adesivos abriria ainda mais o campo para os solventes não agressivos ao sistema nervoso central, para que não haja dependência química e nem problemas em trabalhadores sob exposição.

Portanto, entende-se que exista uma necessidade crescente de dispersões aquosas adesivas de policloropreno que possam ser processadas para se obter formulações adesivas aquosas desta matriz polimérica.

Atualmente, com o avanço das pesquisas e desenvolvimento, existem opções, já patenteadas, de matrizes poliméricas para formulações de adesivos de policloropreno base aquosa, e escolheu-se apresentar um componente que possibilita uma forma diferente de catálise, substituindo aqueles com metais pesados utilizados anteriomente.

A matriz polimérica que será apresentada como referência para este estudo, é uma substância, produzida pela COVESTRO Indústria e Comércio de Polímeros Ltda, denominação atual da BAYER Material Science, denominada Dispercoll ${ }^{\circledR} \mathrm{C} 84$, que é definida como uma dispersão aquosa coloidal do polímero 2-clorobutadieno com taxa alta de cristalização. Sua especificação é de uma dispersão polimérica de 2-poli-clorobutadieno 1,3; com utilização prevista para formulação de adesivos base aquosa para indústrias calçadista, construção, moveleira, e automotivas. A porção polimérica desta dispersão é de $55 \%$ +/- 0,5 (STANDARD DIN 53.563, 1998)

A dispersão de policloropreno é produzida por polimerização em emulsão, de preferência entre de 5 a $45^{\circ} \mathrm{C}$, e com valores de $\mathrm{pH}$ de entre 10 a 14, preferivelmente $\mathrm{pH} 11$ até pH 13. A ativação da reação é realizada com os ativadores convencionais ou sistemas de ativadores, tais como o ácido sulfínico de formamidina, peroxodissulfato de potássio, sistemas redox à base de peroxodissulfato de potássio e opcionalmente um sal de prata, o sal de sódio do ácido antraquinona- $\beta$-sulfónico, em que os compostos, o sal de sódio de ácido sulfínico hidroximetano, sulfito de sódio e dithionite são utilizados em conjunto com o sistema redox. Sistemas redox baseados em peróxidos e hidroperóxidos também são adequados.

Para ajustar a viscosidade dos policloroprenos, agentes de transferência de cadeia convencionais podem ser usados, tais como mercaptanos ou dissulfuretos.

A polimerização é convencionalmente terminada a $50 \%$ a $95 \%$, de preferência entre $60 \%$ e $80 \%$ de conversão do monômero, em que, por exemplo, fenotiazina, terc-pirocatecol dietílico ou hidroxilamina podem ser adicionados como inibidores.

Na polimerização em emulsão, o monômero é incorporado na cadeia de polímero, nas regiões disponíveis, presentes nas várias configurações de cloropreno já apresentadas, ou seja, 
configurações 1 - 4 trans e cis, e nas configurações 1 - 2 e 3 - 4 conforme apresentado na Ilustração 8, página 37 .

O diâmetro médio de partícula primária das partículas de policloropreno é preferencialmente determinado por meio de ultracentrifugação. As partículas de policloropreno têm um diâmetro de partícula primária média de 60-220 nm, de preferência 70-160 nm (MUSCH et al., 2010).

As composições de policloropreno podem conter, adicionalmente, partículas de óxido de zinco na escala nano, cujo tamanho médio de partícula é inferior a $150 \mathrm{~nm}$, de preferência menos do que $50 \mathrm{~nm}$. À medida que as partículas de óxido de zinco nano não são esféricas, é mais correcto falar de tamanho médio de partículas, em vez de diâmetro médio de partícula.

As partículas de óxido de zinco na escala nano podem estar presentes nas composições, tanto como as partículas primárias como sob a forma de aglomerados. As partículas de óxido de zinco nano são convenientemente adicionadas às composições de policloropreno na forma de dispersões aquosas de $\mathrm{ZnO}$. Essas dispersões aquosas podem conter adicionalmente solventes orgânicos de ponto de ebulição elevado, tais como a trietanolamina ou de etilenoglicol ou compostos de modificação da superfície. As partículas de $\mathrm{ZnO}$ podem consistir quer em partículas primárias de $\mathrm{ZnO}$ não aglomerados ou aglomerados de $\mathrm{ZnO}$, ou de misturas de $\mathrm{ZnO}$ partículas primárias dispersas e aglomerados de $\mathrm{ZnO}$, cujas dimensões podem ser como descrito anteriormente. O óxido de zinco, uma vez nas formulações à base de dispersões de policloropreno, atua contra o envelhecimento rápido da junta estrutural e descoloração dos substratos unidos, em razão da liberação de $\mathrm{HCl}$ a partir do polímero de policloropreno.

As composições de policloropreno podem conter outros aditivos, tais como, as partículas de dióxido de silício. As partículas de dióxido de silício em combinação com chumbo e óxido de zinco proporcionarão um aumento na viscosidade da dispersão adesiva. $\mathrm{O}$ uso combinado de óxido de zinco nano e dispersões de dióxido de silício é particularmente preferido. Para produzir as composições de dispersões aquosas do policloropreno base aquosa são convenientemente misturados nas seguintes proporções (MUSCH et al., 2010):

Dispersão de policloropreno: 50 - 99, $95 \%$ em peso;

Hidroxilamina: 0,05 a $2 \%$ em peso;

Dispersão de óxido de zinco: 0 a $10 \%$ em peso;

Dispersão de dióxido de silício: 0 a $40 \%$ em peso;

Pelo menos um antioxidante: 0 a $10 \%$ em peso;

Outro adesivo convencional: $0-79,95 \%$ em peso; 
Substâncias e aditivos auxiliares.

$\mathrm{Na}$ Tabela 4, apresentam-se algumas propriedades do Dispercoll ${ }^{\circledR} \mathrm{C} 84$.

Tabela 4 - Propriedades do Dispercoll ${ }^{\circledR} \mathrm{C} 84$

\begin{tabular}{|c|c|c|c|}
\hline Propriedades & Valores & Unidades de medida & Método \\
\hline Viscosidade & Aprox. 100 & mPa.s & DIN 53019 \\
\hline $\mathrm{pH}$ & Aprox. 13 & & DIN 53606 \\
\hline Massa específica & Aprox. 1,12 & $\mathrm{~g} / \mathrm{cm}^{3}$ & DIN 53757 \\
\hline $\begin{array}{l}\text { Temperatura mínima de formação } \\
\text { de filme }\end{array}$ & Aprox. 5 & ${ }^{\circ} \mathrm{C}$ & DIN 53787 \\
\hline Cristalização & Alta & & \\
\hline Classificação relativa à dureza & & & \\
\hline \multicolumn{4}{|l|}{ Shore A } \\
\hline Conteúdo de gel & Baixo & & Método \\
\hline & & & Bayer \\
\hline
\end{tabular}

Fonte: Dispercoll ${ }^{\circledR}$ C 84 - Product Data sheet - COVESTRO

Depois de formulado, o adesivo de policloropreno poderá ser aplicado por processo de pulverização de mistura, em que a formulação adesiva aquosa e um coagulante (catalisador) são transportados separadamente em uma pistola finalmente misturados no jato de pulverização. A mistura se processa no ar e após o contato entre o adesivo e o coagulante, a cola se deposita no substrato, e acontece o processo de cura. (SKEIST, 1990; MUSCH et al., 2010).

Como já mencionado, se faz necessário a inserção de aditivos, tais como estabilizadores e antioxidantes às dispersões aquosas ou formulações de policloropreno, a fim de proporcionar estabilidade da formulação durante o armazenamento como garantia para a utilização, ou proteger os adesivos contra o envelhecimento ou descoloração.

Os antioxidantes, preferencialmente aqueles, com base em aminas aromáticas secundárias oligofuncionais ou fenóis substituídos oligofuncionais, são também adicionados, tais como produtos do tipo 6-PPD (N-1,3-dimetilbutil)-N'-fenil-p-fenileno-diamina, conforme descrito no Handbuch fuer die Gummiindustrie, 1992. Para esta função, o Vulkanox® DDA, um derivado difenilamina, é particularmente eficaz. 
Os antioxidantes orgânicos, por sua vez não são resistentes à descoloração (aminas aromáticas secundárias oligofuncional) ou são menos eficazes (fenóis oligofuncional substituídos).

A Ilustração 13 apresenta o esquema da produção da matriz polimérica utilizada na formulação de um adesivo de contato de policloropreno base aquosa, semelhante ao que foi utilizado nesta pesquisa, denominada Dispercoll ${ }^{\circledR} \mathrm{C}$.

Ilustração 13 - Esquema representativo da produção da matriz polimérica de policloropreno base aquosa

\section{Produção de Dispercoll ${ }^{\circledR} \mathrm{C}$}

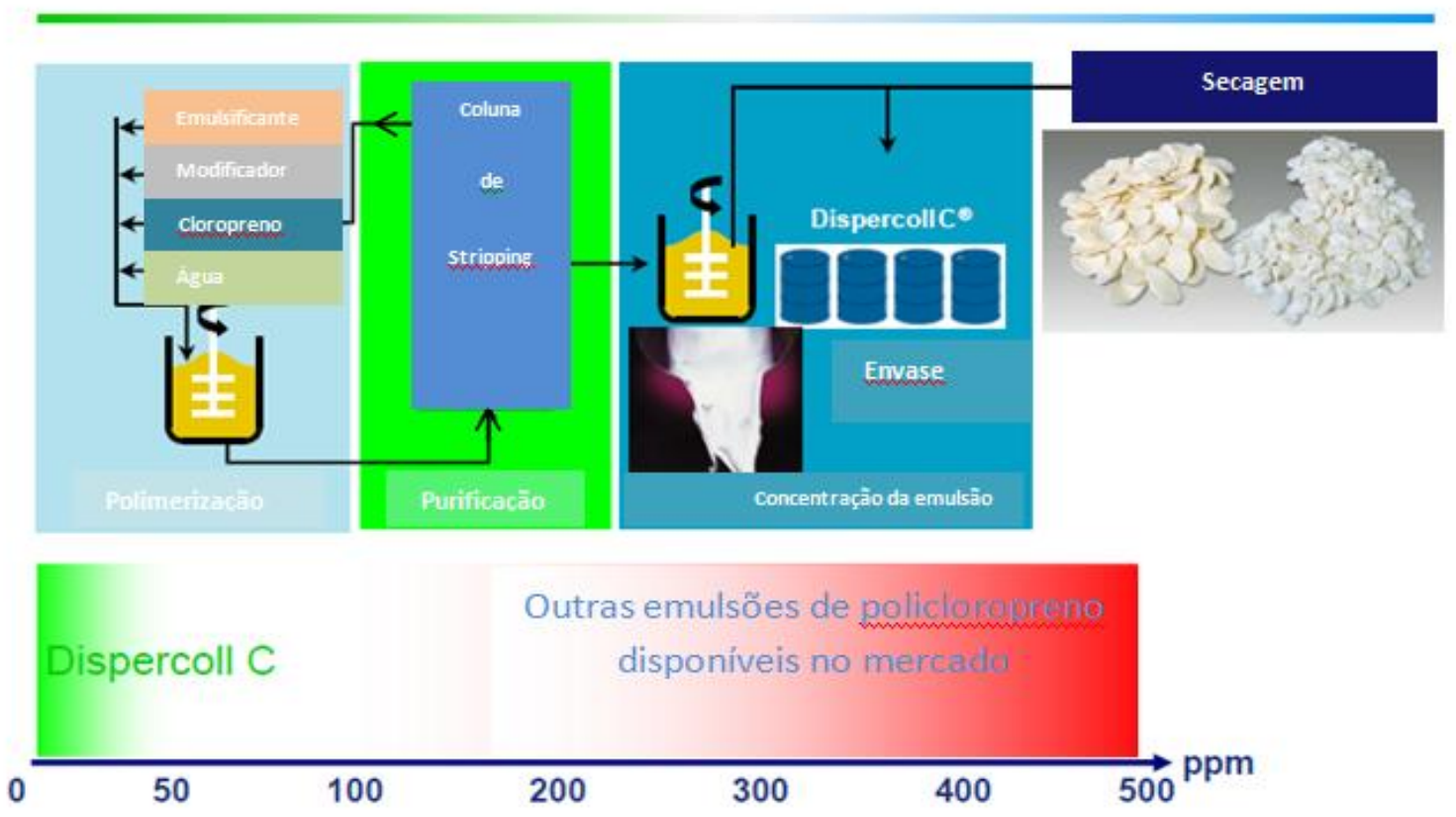

Fonte: Dispercoll ${ }^{\circledR} \mathrm{C} /$ Baypren ${ }^{\circledR}$ Contact Adhesives, 2014

Foi citada a utilização do óxido de zinco como aditivo na formulação do adesivo de policloropreno base aquosa, sendo este inserido com granulometria na escala nanométrica, pois um dos problemas da inserção deste óxido era a possibilidade de sedimentação do mesmo, o que geraria dificuldades no processo de aplicação do adesivo sobre o substrato.

Porém, dentro dos conhecimentos da nanociência, quando se trabalha nesta ordem de grandeza para as substâncias, forças como a de gravidade, atrito e combustão ficam em segundo plano, e os aspectos relevantes das forças eletrostáticas que são predominantes são as 
forças de van der Waals e o movimento browniano. Adicionalmente a esses dois aspectos, tem-se também o efeito de tamanho, que pode fazer mudar algumas propriedades, como por exemplo, partículas com propriedades magnéticas podem ter esta propriedade alterada para uma situação de superparamagnetismo. Outra situação pode ser originada pelo aumento da área superficial de nanomateriais, que provocam um aumento significativo em sua reatividade. Esta característica é muito relevante para uma substância que também é utilizada como espessante em uma formulação. (DURÁN; MATTOSO; MORAIS, 2006).

Existem outros tipos de matrizes poliméricas da família Dispercoll ${ }^{\circledR} \mathrm{C}$, tais como Dispercoll $^{\circledR} \mathrm{C} 74$ e Dispercoll $^{\circledR} \mathrm{C}$ VPLS 2325, porém, cada um deles possui propriedades específicas e para esta pesquisa, cujo foco são os adesivos para indústrias moveleiras, foi escolhido o do Dispercoll ${ }^{\circledR} \mathrm{C} 84$ como matriz polimérica principal.

$\mathrm{O}$ que varia entre os tipos de matrizes poliméricas da família Dispercoll ${ }^{\circledR} \mathrm{C}$ são a taxa de cristalização e a organização do polímero na matriz.

Existe uma outra linha da família Dispercoll ${ }^{\circledR}$, denominada Dispercoll ${ }^{\circledR}$ S 3030 que por sua vez, é utilizada como um aditivo especial que será citado na formulação do adesivo base aquosa. Esta substância é definida como uma solução coloidal aquosa aniônica de dióxido de silício amorfo, que atua como espessante em conjunto com o óxido de zinco, atuando sobre a viscosidade do adesivo formulado.

É interessante neste momento da explanação apresentar uma comparação entre as formulações do adesivo de policloropreno base solvente tradicional e base aquosa para posterior parâmetro de comparação. Na Ilustração 14 apresentam-se as duas propostas de formulação.

Ilustração 14 - Formulação básica de adesivo de policloropreno base solvente e base aquosa

\begin{tabular}{|c|c|c|c|c|c|c|c|}
\hline \multicolumn{3}{|c|}{ FORMULAÇÃO BASE SOLVENTE } & \multicolumn{5}{|c|}{ FORMULAÇÃO BASE AQUOSA } \\
\hline Produto & phr & Variações & Produto & Função & $\begin{array}{l}\text { Adicionado } \\
\text { como }\end{array}$ & $\begin{array}{l}\text { Sólidos } \\
\text { (\%) }\end{array}$ & phr \\
\hline Baypren $^{\circledR}$ & 100 & 200-300 séries & $\begin{array}{l}\text { Dispercoll } \\
{ }^{\circledR} \mathrm{C}\end{array}$ & Polímero & dispersão & 55 & 100 \\
\hline $\begin{array}{l}\text { Dióxido de } \\
\text { zinco ativo }\end{array}$ & 2 & - & $\begin{array}{l}\text { Rhenofit } \\
\text { DDA-50 EM }\end{array}$ & Antioxidante & dispersão & 50 & 1 \\
\hline $\begin{array}{l}\text { Óxido de } \\
\text { magnésio }\end{array}$ & 3 & - & $\begin{array}{l}\text { Borchers VP } \\
9802\end{array}$ & $\mathrm{ZnO}$ & dispersão & 25 & 2 \\
\hline Resina & 40 & alquilternopefenol & $\begin{array}{l}\text { DISPERCOLL } \\
\text { S } 3030\end{array}$ & aditivo & dispersão & 30 & 10 \\
\hline Solventes & 600 & $\begin{array}{l}\text { Tolueno, } \\
\text { ciclohexano, MEK }\end{array}$ & Rhenofit DDA & -50 EM: lanxess & & & \\
\hline Aditivos & $5-30$ & $\begin{array}{l}\text { Sílica, borracha } \\
\text { clorada }\end{array}$ & Borchers VP & 802: Borchers & & & \\
\hline
\end{tabular}

Fonte: Adaptado de Dispercoll ${ }^{\circledR}$ C/Baypren ${ }^{\circledR}$ Contact Adhesives, 2014 
Observando as formulações, verifica-se que Baypren ${ }^{\circledR}$ (adesivo base solvente) e Dispercoll ${ }^{\circledR} \mathrm{C}$ (adesivo base aquosa) são as matrizes poliméricas utilizadas, o óxido de zinco ativo, o Rhenofit ${ }^{\circledR}$ DDA 50 EM e Borchers ${ }^{\circledR}$ VP 9802 são os antioxidantes e como aditivos, compostos a base de sílica. Os solventes orgânicos especificados compõem a formulação que utiliza Baypren ${ }^{\circledR}$ como matriz polimérica, e a água está presente na matriz polimérica Dispercoll ${ }^{\circledR} \mathrm{C}$ (Dispercoll ${ }^{\circledR} \mathrm{C} /$ Baypren $^{\circledR}$ Contact Adhesives, 2014).

Depois do adesivo formulado, este deverá ser aplicado sobre o substrato por meio de um equipamento que permita a catálise do adesivo com gás carbônico $\left(\mathrm{CO}_{2}\right)$ concomitantemente ao processo de aplicação. A catálise com gás carbônico é sugerida na patente CA 2735849, que se refere às formulações à base de dispersões anionicas aquosas estabilizadas de polímero, contendo policloropreno, que foram misturadas com dióxido de carbono $\left(\mathrm{CO}_{2}\right)$, com a finalidade de produzir e aplicar adesivos e selantes (ACHTEN, et al. 2009).

A utilização do dióxido de carbono como um neutralizante e agente coagulante em dispersões ionicamente estabilizadas já foi descrita muitas vezes na literatura. O dióxido de carbono é utilizado para formar um ácido fraco que reduzirá o pH da dispersão de polímero ionicamente estabilizado, com o objetivo de promover a coagulação do adesivo, facilitando a formação de aglomerados, melhorando as propriedades coesivas e durabilidade do produto.

Neste processo, o adesivo e o agente de coagulação, no caso o $\mathrm{CO}_{2}$, são alimentados separadamente em uma pistola de pulverização, na qual ocorre a mistura no jato de pulverização, sendo que a coagulação ocorre no ar, condição esta ideal para que não haja comprometimento do equipamento de aplicação, como por exemplo, entupimentos do sistema de aplicação(ACHTEN, et al. 2009).

O equipamento e o processo de aplicação serão apresentados posteriomente na seção 5.2. 


\section{CONDICIONAMENTO MAGNÉTICO DE POLÍMEROS NANOESTRUTURADOS E DE SOLUÇÕES AQUOSAS.}

Neste momento do desenvolvimento do trabalho, faz-se uma pausa, para a inserção de um assunto não muito usual na produção de adesivos. Poucas referências existem a respeito do condicionamento magnético de matrizes poliméricas, e no que diz respeito à aplicação desse fundamento em adesivos, nada foi encontrado, porém, alguns indícios indicaram a possibilidade de provocar alguma modificação no adesivo se este fosse submetido à campos magnéticos, apresentados a seguir.

Atualmente, com o aumento da utilização da nanotecnologia para o desenvolvimento de materiais novos, principalmente compósitos, tem-se obtido informações da utilização de nanocompostos para melhorar as propriedades de polímeros, principalmente no que diz respeito ao reforço desses materiais. Resultados mais interessantes são relatados quando alguns nanocompostos introduzidos nas matrizes poliméricas são submetidos a aplicação de campos magnéticos.

Um dos trabalhos que tratam desse assunto, apresentado no $59^{\circ}$ Congresso Brasileiro de Cerâmica, em 2015, por Dr. André Rocha Studart relata em suas pesquisas a obtenção de resultados de organização semelhantes com aqueles existes na organização hierárquica complexa de materiais biológicos, como ossos, dentes, plantas e conchas por meio da implementação de nanoestruturas em matrizes poliméricas, que permitirão a criação de materiais com combinação de propriedades e funcionalidades incomuns. Segundo ele, apesar dos esforços em curso para entender os processos mediados por células complexas que levam a tais arquiteturas hierárquicas, imitando sinteticamente a organização estrutural de materiais naturais, continua a ser um grande desafio. Uma abordagem alternativa é conceber rotas novas de montagem dirigida para organizar blocos de construção em estruturas coloidais bioinspirados na ausência de controle celular. Uma nova abordagem apresentada para obtenção de compósitos à base de polímeros que exibem orientação deliberada de reforçar partículas de cerâmica é a utilização de campos magnéticos de intensidade ultra baixa. A capacidade de controlar a posição e orientação de partículas de reforço dentro de uma matriz de polímero conduz a formação de estruturas heterogéneas com rigidez incomum, resistência ao desgaste e com memória de forma, com isto, o pesquisador entende que esses conceitos de design para sistemas puramente inorgânicos permitem a criação de cerâmicas com tenacidade notável ou com efeitos de auto-modelagem sem precedentes. As propriedades incomuns alcançadas nestes exemplos ilustram o potencial grande desta abordagem bioinspirado na 
criação de compostos sintéticos e cerâmicas com comportamento funcional rico usando um conjunto limitado de blocos de construção.

Estudos citados em dissertação de mestrado (RISI, 2010), da UDESC, Universidade do Estado de Santa Catarina, comentam que é possível promover o alinhamento de nanotubos de carbono (NC) dispersos em matrizes poliméricas por meio de campo magnético externo, em razão à sua elevada susceptibilidade magnética A susceptibilidade magnética $(\chi)$ é uma importante propriedade que determina o grau de magnetização dos materiais, em resposta a um campo magnético. Verificou-se que a susceptibilidade magnética dos NC varia de acordo com a direção do campo magnético aplicado, com o diâmetro dos NC ( $\chi$ é uma função crescente em relação ao diâmetro) e com a temperatura (decrescente com a temperatura). Tal fato permite direcionar os NC quando aplicado um campo magnético externo. São muitas as citações a respeito desse assunto, porém não serão aqui abordadas para não desviar o foco da pesquisa.

O fato de relevância é que se conseguem modificações em propriedades de compósitos de matrizes poliméricas nanoestruturados, quando submentidos à aplicação de campos magnéticos. Citou-se a interferência de campos magnéticos em matrizes poliméricas que contenham a inserção de nanocompostos, pois nesta tese, também se trabalha com uma matriz polimérica aditivada com nanocomposto de zinco, portanto, com base nos estudos já existentes, embora observadas as diferenças de universos de aplicação, inferiu-se que seria possível observar alguma mudança de comportamento do produto final (o adesivo formulado) se à ele fosse aplicado um campo magnético.

Segundo Mayrink et al. (2014) o óxido de zinco (ZnO) vem se destacando em razão de suas propriedades mecânicas, elétricas, magnéticas, ópticas e químicas. No óxido de zinco tais propriedades dependem principalmente do tamanho e morfologia de suas partículas.

Portanto, se o óxido de zinco possui propriedades magnéticas, que podem ser diferenciadas pelo tamanho e morfologia de suas partículas, talvez a sua presença como aditivo no adesivo de policloropreno base aquosa possa, quando na presença de campos magnéticos, produzir alguma alteração nas propriedades do referido adesivo.

Além disso, estudos também indicam que a água é susceptível a aplicação de campos magnéticos, e no caso desta pesquisa, a matriz polimérica utilizada na formulação do adesivo está em base aquosa, portanto, mais um indício de probabilidade de ocorrer algum evento de diferenciação nas propriedades de adesão após aplicação de campos magnéticos.

Para efeito de conhecimento, apresenta-se o estado da arte sobre o condicionamento magnético da água. 
O condicionamento magnético da água é um recurso simples no qual a água passa por um campo magnético e altera algumas de suas propriedades físico químicas. Este condicionamento magnético utilizado na prevenção de sedimentação e remoção de sedimentos acumulados na água, foi primeiramente patenteado por Vermeiren, na Bélgica, em 1953, sendo então reconhecido como descobridor do fato de que campos magnéticos afetam as propriedades da água.

Historicamente, a água foi estudada com o auxílio do raio $\mathrm{X}$ por Morgan; Warren (1938) e depois por Narten; Levy (1969). A primeira conclusão do trabalho foi que a água era ligada tetraedricamente de forma similar a que ocorre no gelo hexagonal. Ainda essa visão, quase cristalina da água era insatisfatória por não levar em consideração a falta de ordem em grande parte do líquido e por ser necessário idealizar moléculas intersticiais no arranjo reticular para se aproximar dos valores experimentais quantitativos.

Muitos dos artigos encontrados na literatura que propõem mostrar a evidência da ação de campos magnéticos em diversas áreas, às vezes, omitem detalhes experimentais importantes que impossibilitam ao leitor repetir e comprovar o efeito reportado. Como o embasamento teórico que propõe explicar o fenômeno ainda é novo e as variáveis que influenciam o sistema ainda são desconhecidas pela maioria dos autores no mundo ocidental, as oscilações estatísticas da eficácia do processo de condicionamento da água verificadas na prática são grandes, por isso, existem muitas críticas e ceticismo em relação ao assunto.

Joshi; Kamat (1966) submeteram água tri-destilada a campos magnéticos de 0,19 a 0,57 T. Seus resultados mostraram que o $\mathrm{pH}$ aumenta progressivamente de 0,35-0,62 unidades; a tensão superficial $\gamma$ diminui de 5,3 dina/cm para 1,6 dina/cm, e a constante dielétrica $\varepsilon$ aumenta 1,5 unidades. Admite-se que a diminuição da concentração dos íons $\mathrm{H}_{3} \mathrm{O}^{+}$provavelmente resulta de uma mudança na constante de ionização da água sob a influência de um campo magnético, apesar de não haver nenhuma explicação para estas mudanças em $\gamma$ e $\varepsilon$.

Em Belova (1972), o sistema de condicionamento da água por campo magnético, é um método totalmente passivo sem presença de produtos químicos para tratamento de água. A aplicação deste condicionamento permite eliminar o acúmulo de incrustações e problemas de corrosão. Belova discorre sobre a inversão dos spins dos elétrons de todos os átomos envolvidos nas soluções, quando expostas a um campo magnético. Essa inversão também afeta as pontes de hidrogênio na água. Tanto os íons como os elétrons, quando submetidos a um campo magnético, no caso do condicionamento, se movimentam em um plano 
perpendicular com movimentos circulares e os fenômenos de paramodificação e ortomodificação utilizam $36 \mathrm{cal} / \mathrm{mol}$, isso incrementa o número de colisões e a formação dos centros de cristalização.

Basicamente as aplicações de um campo magnético são da ordem de 0,5 à 1,4 T. Tal intensidade em função do fluxo d'água penetrará prontamente nas tubulações, sendo esse fluxo denso o bastante para fazer com que uma corrente elétrica seja gerada na água.

Os efeitos do campo magnético na água estão relacionados com várias de suas propriedades físico químicas, tais como susceptibilidade magnética, condutividade elétrica, ponto de ebulição, tensão superficial, pontes de hidrogênio (BUENO, 1978), que têm seu comportamento alterado. A inversão na rotação dos spins dos elétrons (BELOVA, 1972) define a orientação, alinhamentos dos clusters e dos íons presentes na água, alterando seu comportamento natural (KRONENBERG, 1987). A modificação que ocorre está relacionada apenas com o comportamento físico da água, não afeta a sua estrutura química nem a de seus íons, isto é, não ocorrem reações químicas com os íons.

Gehr et al.(1995) fizeram um estudo criterioso da solubilidade de $\mathrm{CaSO}_{4}$ em água quando estas eram expostas a um campo magnético de 4,75 $\mathrm{T}$, produzido por um espectrômetro de ressonância magnética nuclear. Foram utilizados vários parâmetros de medida e observação. Dentro das condições específicas do experimento, o condicionamento magnético induziu a precipitação dos cristais de gipsita (sulfato de cálcio). Os autores concluíram que tratamentos magnéticos podem ser eficientes na prevenção de sedimentação, agindo para promover uma cristalização no lugar da precipitação que ocorre em superfícies sólidas.

Lazarenko; Zhuravlev (1985) reportaram que a água condicionada magnéticamente, utilizada na preparação de concreto, melhora a qualidade do mesmo, conferindo-lhe uma ótima resistência ao impacto. A porosidade do concreto e a absorção de água tornam-se menores, levando a diminuição no tempo de cura e a maior dureza do material.

Beaugnon; Tournier (1991) observaram que vários materiais diamagnéticos como bismuto, estrôncio, água, etanol, madeira, plástico, acetona e grafite, poderiam ser levitados sob campos magnéticos com gradientes elevados, gerados por um ímã super-condutor vertical de 27 T. Tais materiais são fracamente diamagnéticos e, quando submetidos a um gradiente do campo magnético, tendem a ser conduzidos das regiões de campo forte para aquelas de campo mais fraco. Quando a força resultante é maior e mais forte que a gravidade, ocorre a levitação. 
Ueno; Iwasaka (1994) fizeram um estudo do comportamento hidrodinâmico da água, observando a sua partição física na presença de campos magnéticos de $8 \mathrm{~T}$, gerados a partir de ímãs super condutores horizontais. Eles observaram que a água destilada, preenchendo a metade do volume de um recipiente, divide-se em duas partes, quando exposta ao campo magnético citado. Os níveis de água nas laterais sobem, formando paredes de água. As paredes de água também são formadas nas temperaturas de transição da água $\left(0{ }^{\circ} \mathrm{C}\right.$ e 100 ${ }^{\circ} \mathrm{C}$ ). Esse comportamento também foi observado em uma solução isotônica de cloreto de sódio ( $\mathrm{NaCl}$ a $9 \%$ em peso) e em várias outras soluções de cloreto de sódio em diferentes concentrações.

Nesse caso, as mudanças absolutas na altura da superfície das soluções, no centro do recipiente, diminuiram com o aumento da concentração de cloreto de sódio na solução. Uma variação do experimento mostrou o efeito do campo magnético na velocidade do fluxo de água destilada, o qual diminui com o aumento da intensidade do campo.

Katsuki et al. (1996) estudaram a influência de um campo magnético forte (8 T) no crescimento de cristais de um composto diamagnético, a benzofenona. A direção do eixo longitudinal das agulhas dos cristais tende a se alinhar perpendicularmente à direção do campo aplicado, em que o grau de orientação depende da sua intensidade. Na ausência do campo magnético, as agulhas orientam-se aleatoriamente. Considera-se que a orientação magnética de cristais de um composto diamagnético ocorre quando este possui susceptibilidade diamagnética anisotrópica alta.

Freitas (1999) realizou um trabalho exaustivo sobre o efeito de campos magnéticos na cristalização de soluções aquosas, onde demonstrou claramente como os cristais se modificam.

Aleksandrov; Barannikov; Dobritsa (2000) demonstraram experimentalmente por meio de análise térmica (DSC), que o comportamento da solidificação da água destilada se alterava proporcionalmente à aplicação de um campo magnético externo. Na ausência de campo magnético, a água apresentava temperatura crítica de supercongelamento média de 7,6 ${ }^{\circ} \mathrm{C}$ e quando se aplicava campo magnético a temperatura de supercongelamento se aproximava a $0{ }^{\circ} \mathrm{C}$, até atingir este valor quando se aplicava campos magnéticos com intensidades iguais ou maiores a 0,5 $\mathrm{T}$.

Faigle; Porto (2000) demostraram a diminuição da tensão superficial, aumento da condutividade elétrica e aumento da pressão de vapor da água desionizada, depois de submetida a um condicionamento magnético, além de alterações nas propriedades biológicas desta água e correlacionaram algumas das mudanças físicas com as biológicas. 
Barboza (2002) demonstrou como o campo magnético alterava a estrutura do carbonato de cálcio, e apresenta a forma esférica da aragonita.

Landgraf et al. (2004) avaliou o efeito da exposição de soluções aquosas contendo carbonato de cálcio ao campo magnético, na condutividade elétrica, pH e tensão superficial.

Há pelo, menos 167 patentes sobre assunto envolvendo água magnetizada, maneira errônea com que tem se denominado este tipo de condicionamento de água encontrado na literatura de patentes. (CHEMICAL ABSTRACTS, 1990-2000). 


\section{MATERIAIS E MÉTODOS}

\subsection{MATERIAIS}

A parte experimental dessa tese foi desenvolvida nos laboratórios de pesquisa dos cursos de Engenharia Química e Química da Faculdade de São Bernardo do Campo, FASB, faculdade de referência na formação de Químicos desde 1970; local onde realizo minhas funções de docente nos dois cursos citados.

A metodologia deste trabalho pode ser definida como sendo uma pesquisa bibliográfica e documental, experimental e comparativa, e, para isso, foram organizados quatro grupos de amostras, contendo 25 conjuntos de substratos cada um. Os grupos de amostras foram denominados da seguinte maneira:

Grupo 1 (A1): Amostras nas quais foram aplicados adesivo de contato de policloropreno base solvente da marca Colabras $^{\circledR}$, produzido pela empresa Brascola, adquirido já formulado, pronto para uso.

Grupo 2 (A2): Amostras nas quais foram aplicados adesivo de contato de policloropreno base aquosa da marca Cascola $^{\circledR}$, produzido pela empresa Henkel, adquirido já formulado, pronto para uso.

Grupo 3 (A3): Amostras nas quais foram aplicados o adesivo de contato de policloropreno base água, formulado nos laboratórios da FASB, segundo orientações técnicas do departamento de desenvolvimento da empresa COVESTRO, denominação atual da Bayer Materialscience, a partir de $1^{\mathrm{o}}$ de julho do corrente ano.

Grupo 4 (A4): Amostras nas quais foram aplicados o adesivo de contato de policloropreno base água, formulado nos laboratórios da FASB, segundo orientações técnicas do departamento de desenvolvimento da empresa COVESTRO, porém, antes da aplicação, o adesivo já formulado foi submentido à condicionamento magnético.

Como um dos objetivos do trabalho é verificar a capacidade de adesão do adesivo de contato de policloropreno base aquosa, aditivado com nanocompostos, condicionado magneticamente e catalisado com gás carbônico concomitantemente ao processo de aplicação do adesivo, relatam-se a partir de agora, as especificações dos produtos utilizados, bem como o método utilizado para realizar a experiência.

Em primeiro lugar, serão apresentados os adesivos prontos para uso e as matérias primas utilizadas na formulação dos adesivos. 
Os dois adesivos prontos para uso utilizados neste estudo, como citado anteriormente, foram adesivos comerciais de referência, encontrados no mercado:

a) Adesivo pronto para uso de policloropreno base solvente denominado Colabras ${ }^{\circledR}$ sem tolueno, da empresa Brascola, lote: 14F2564, validade 30 junho 2015, viscosidade Brookfield, modelo LVR (sp 3, $10 \mathrm{rpm}$ ) igual a $2000 \mathrm{mPa} . \mathrm{s}$, teor de sólidos (estufa $180{ }^{\circ} \mathrm{C}, 15$ minutos) igual a $18,7 \%$; que a partir de agora será denominado de adesivo base solvente comercial.

b) Adesivo de contato Cascola $^{\circledR}$, composto de policloropreno e resinas sintéticas em base aquosa, da empresa Henkel, lote 1406660, validade 15 de abril de 2015, viscosidade Brookfield, modelo LVR (sp 3, $10 \mathrm{rpm}$ ) igual a $350 \mathrm{mPa} . \mathrm{s}$, teor de sólidos (estufa $180{ }^{\circ} \mathrm{C}, 15$ min) igual a $48 \%$; que a partir de agora será denominado adesivo base água comercial.

Observa-se que os dois adesivos de contato escolhidos são de famílias diferentes, um com base solvente e outro, base aquosa. Esta escolha foi feita para possibilitar a comparação das capacidades de adesão entre as duas famílias de adesivos disponíveis no mercado.

As matérias primas que serão apresentadas a partir de agora, foram aquelas utilizadas na formulação do adesivo de contato de policloropreno base água, com formulação sugerida pela COVESTRO, utilizando nanoaditivos.

a) Dispercoll $\mathrm{C}^{\circledR} 84$, lote 403331A22, validade 30 de abril de 2015, viscosidade Brookfield, modelo LVR (sp 3, $10 \mathrm{rpm}$ ) igual a $100 \mathrm{mPa} . \mathrm{s}$, massa específica $1,12 \mathrm{~g} / \mathrm{cm}^{3}$, teor de sólidos (estufa $180{ }^{\circ} \mathrm{C}, 15 \mathrm{~min}$ ) igual a $55 \%$ e pH aproximadamente 13 (COVESTRO).

b) Dispercoll $C^{\circledR}$ VPLS 2372/1, lote 10929A33 validade 30 de abril de 2015, viscosidade Brookfield, modelo LVR (sp 3, 10 rpm) igual a $100 \mathrm{mPa} . \mathrm{s}$, massa específica 1,12 $\mathrm{g} / \mathrm{cm}^{3}$, teor de sólidos (estufa $180{ }^{\circ} \mathrm{C}, 15 \mathrm{~min}$ ) igual a $58 \%$ e $\mathrm{pH}$ aproximadamente 13 (COVESTRO).

c) Dispercoll $S^{\circledR} 3030$, validade 30 de aril de 2015, viscosidade Brookfield, modelo LVR (sp 3, $10 \mathrm{rpm}$ ) igual a $100 \mathrm{mPa}$.s , massa específica $1,21 \mathrm{~g} / \mathrm{cm}^{3}$, tamanho da partícula de aproximadamente $9 \mathrm{~nm}$, superfície específica de aproximadamente $300 \mathrm{~m}^{2} / \mathrm{g}$, concentração 30 $\%$ e pH aproximadamente 10 (COVESTRO).

d) Rhenofit $\mathrm{DDA}^{\circledR}$ 50: Substância derivada da difenilamina em emulsão aquosa. Utilizado como um antioxidante para os compostos de látex e adesivos base aquosa. Previne danos causados pela ação do oxigênio e do calor, além de ser eficiente contra a formação de crack dinâmica (craquelamento) causada pelo oxigênio. A concentração do derivado de difenilamina é de $50 \%$, lote 0700008972, viscosidade Brookfield, modelo LVR (sp 3, 10 rpm) igual a $100 \mathrm{mPa} . \mathrm{s}$ e sua massa específica é $1 \mathrm{~g} / \mathrm{cm}^{3}$ (Rhein Chemie Rheinau GmbH). 
e) VP Disp $\mathrm{ZnO}^{\circledR} 20$ DW: Dispersão de óxido de zinco em água, lote 143042615 , validade 30 de abril de 2015, viscosidade Brookfield, modelo LVR (sp 3, $10 \mathrm{rpm}$ ) igual a 10 mPa.s (cP), massa específica $1,38 \mathrm{~g} / \mathrm{cm}^{3}$ (EVONIK Industries).

Além dessas matérias primas, cabe comentar sobre os conjuntos de substratos (corpos de prova) sobre os quais foram aplicados os adesivos.

Cada conjunto de substrato era composto de duas partes. Uma de madeira e outra de fórmica. A madeira ipê, do gênero Tabebuia, especificamente o ipê-roxo (Tabebuia impetiginosa) foi escolhida por ser uma das mais difíceis de serem coladas. As dimensões de cada parte do conjunto eram de $100 \mathrm{~mm}$ por $25 \mathrm{~mm}$.

\subsection{MÉTODOS}

Em primeiro lugar realizou-se a preparação dos substratos, que já vieram cortados nas dimensões padronizadas, e doados pela Empresa Brascola.

Foi feito um lixamento em equipamento específico, na superfície em que foi aplicado o adesivo apresentado na Ilustração 15.

Ilustração 15 - Preparação dos corpos de prova

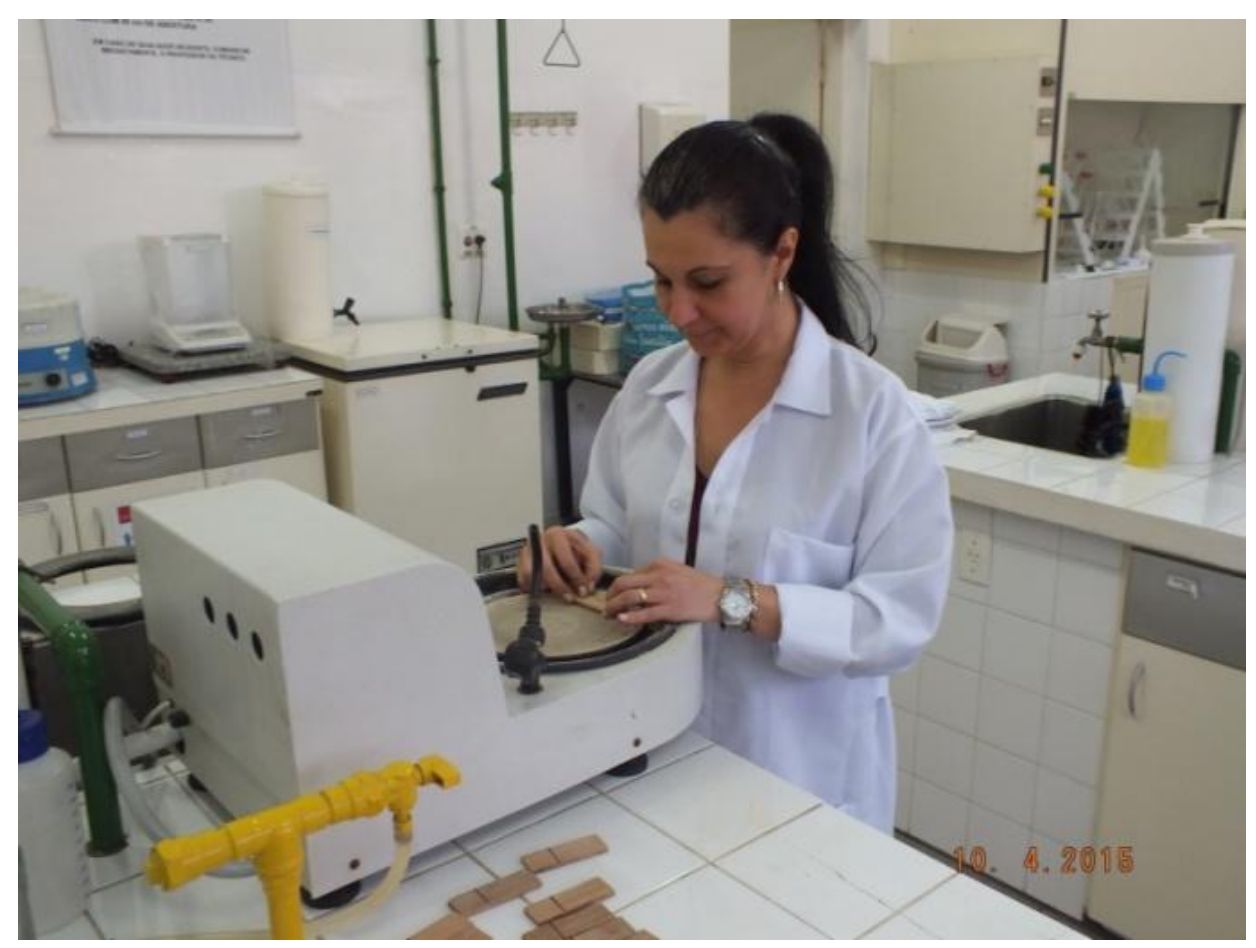

Fonte: Acervo fotográfico do autor, 2015 
O equipamento utilizado para o lixamento das peças de ipê apresentado na Ilustração 16, foi uma Politriz Lixadeira Metalográfica, modelo PL01 confeccionada em alumínio e protegida com pintura eletrostática a pó, com excelente resistência à corrosão, em versão simples (um prato), com uma velocidade de trabalho de $600 \mathrm{rpm}$, apropriada para laboratórios metalográfico, físico, petrográfico, mineralogia, geologia, odontologia e análises químicas. (TECLAGO, 2015).

Ilustração 16 - Politriz Lixadeira Metalográfica

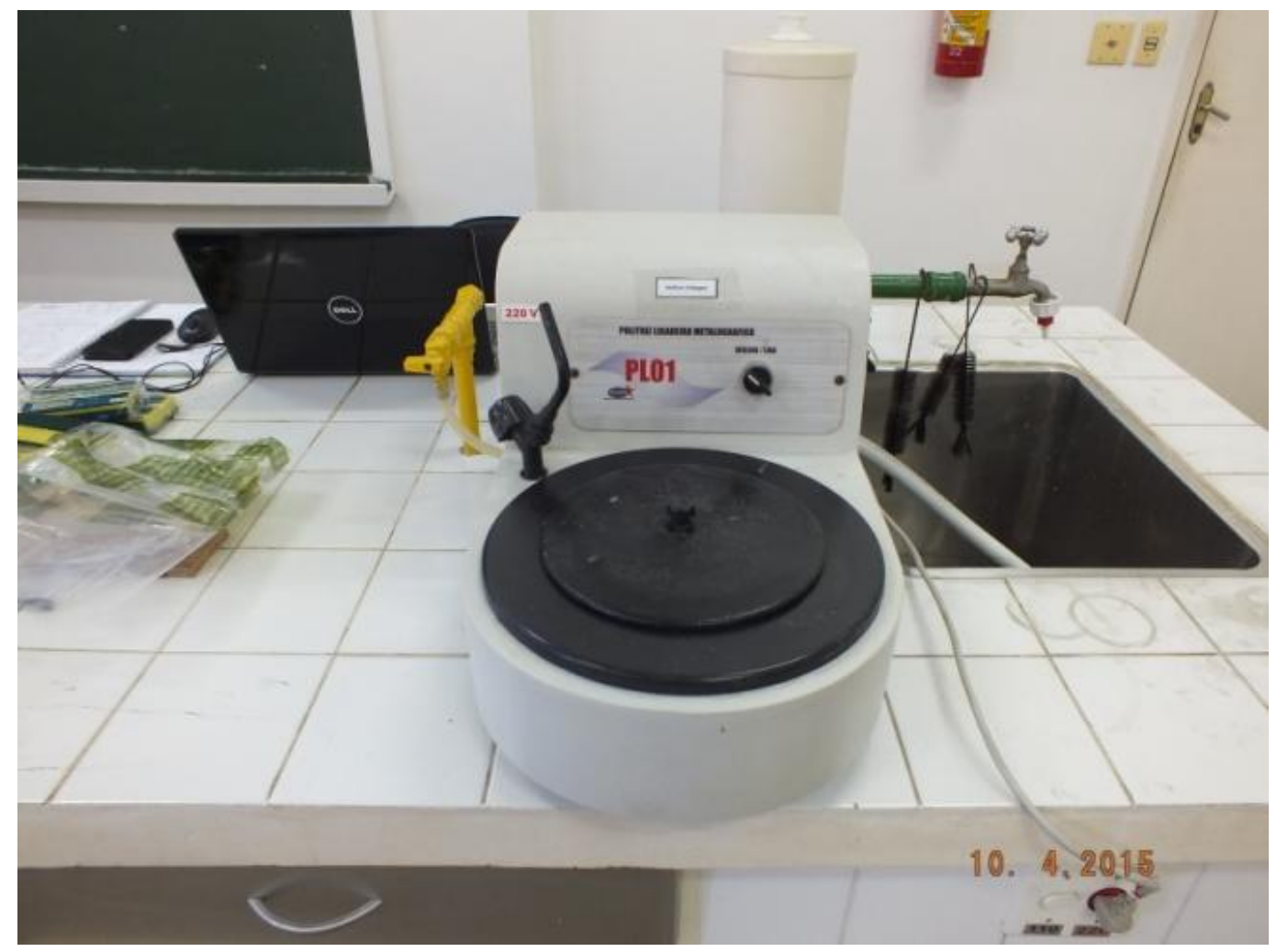

Fonte: Acervo fotográfico do autor, 2015

Após o lixamento e limpeza dos 100 conjuntos de substratos, providenciou-se a pesagem das matérias primas segundo a formulação sugerida pela COVESTRO, descrita na Tabela 5. 
Tabela 5 - Formulação do adesivo de contado de policloropreno base aquosa

\begin{tabular}{cc}
\hline Matérias primas & Quantidade individual (\%) \\
\hline Dispercoll C 84 & 59,32 \\
Dispercoll C VPLS 2372/1 & 25,42 \\
Rhenofit DDA 50 & 1,70 \\
VP Disp ZnO 20 DW & 0,85 \\
Dispercoll S 3030 & 12,71 \\
\hline
\end{tabular}

Fonte: Dispercoll ${ }^{\circledR} \mathrm{C} /$ Baypren $^{\circledR}$ Contact Adhesives, 2014

A pesagem das matérias primas foi efetuada em equipamento apresentado na Ilustração 17.

Ilustração 17 - Pesagem das matérias primas

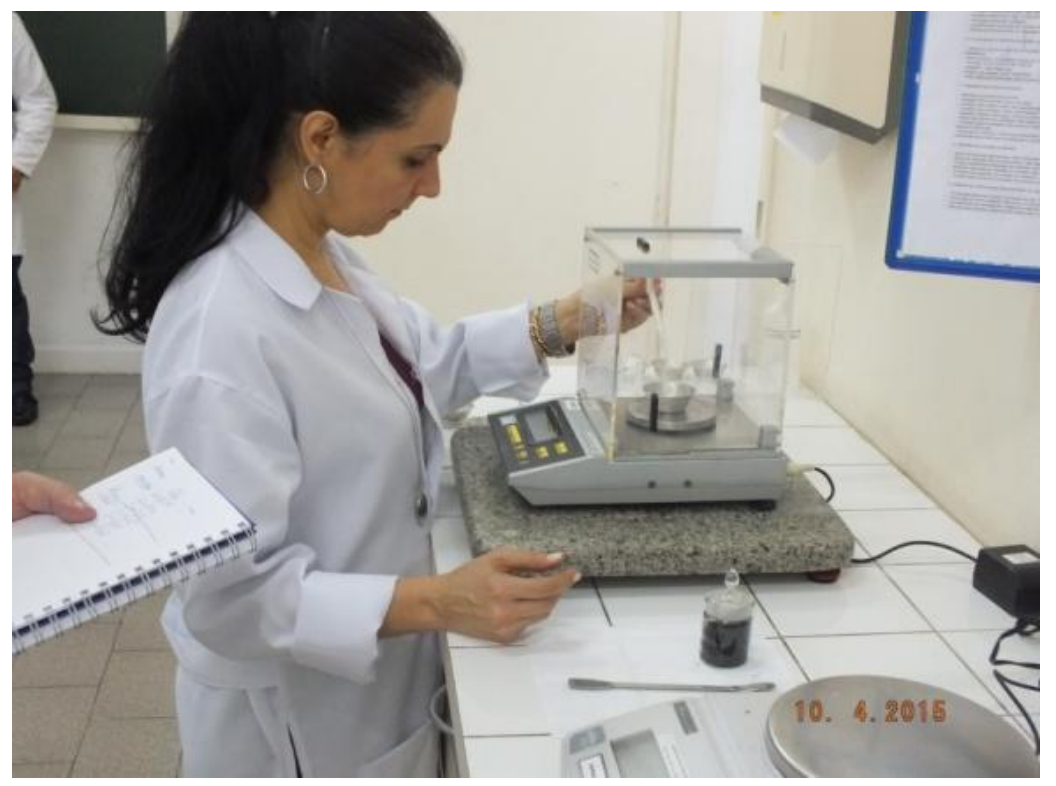

Fonte: Acervo fotográfico do autor, 2015

Após a pesagem de todas as matérias primas, passou-se para o processo de formulação, utilizando um agitador mecânico de torque microprocessado alto, modelo Q250M1,110 V, $100 \mathrm{~W}$, da empresa QUIMIS, $\mathrm{n}^{\circ}$ de série 13040004. O processo de formulação seguiu algumas determinações, como por exemplo, a ordem de inserção das matérias primas, que deve ser exatamente aquela apresentada na formulação respeitandose o intervalo de tempo entre as adições, processo este representado na Ilustração 18. 
Ilustração 18 - Preparação do adesivo

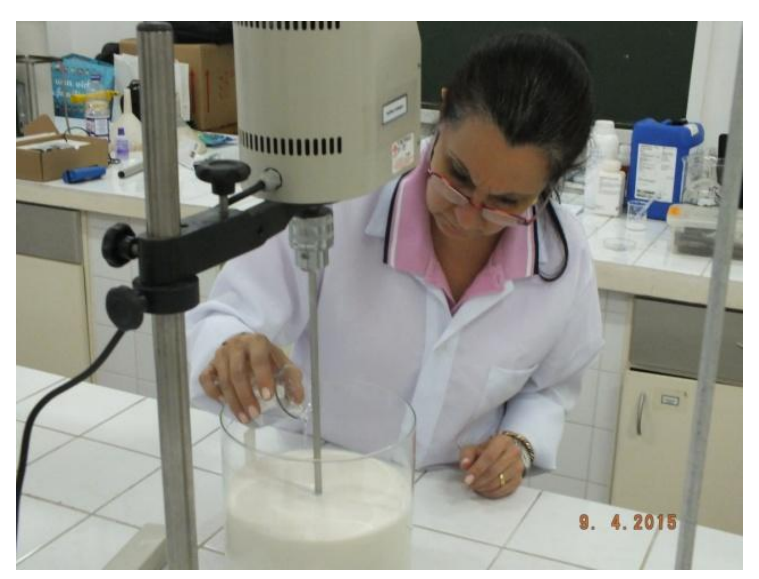

Fonte: Acervo fotográfico do autor, 2015

Adicionou-se em um recipiente de vidro o Dispercoll ${ }^{\circledR}$ C 84 e o Dispercoll ${ }^{\circledR}$ C VPLS 2372/1, mantendo os dois em agitação de $200 \mathrm{rpm}$ por 5 minutos. Após este tempo, adicionou-se o Rhenofit $\mathrm{DDA}^{\circledR} 50$, mantendo-se a agitação de $200 \mathrm{rpm}$ por mais 8 minutos.

Preparou-se a diluição do VP Disp ZnO 20 DW para $25 \%$, já que esta estava diluída em 50 $\%$, inserindo-se no agitador por mais 8 minutos a $200 \mathrm{rpm}$.

Em seguida, adicionou-se o Dispercoll $S^{\circledR} 3030$ que permaneceu em agitação a 200 rpm por mais 10 minutos. Findo este tempo, a formulação estava completada. Para garantir eficiência da intimização dos constituintes da fórmula, deixou-se a mistura por mais $1 \mathrm{~h}$, com o agitador programado em 200 rpm, conforme Ilustração 19.

Ilustração 19 - Finalização da formulação

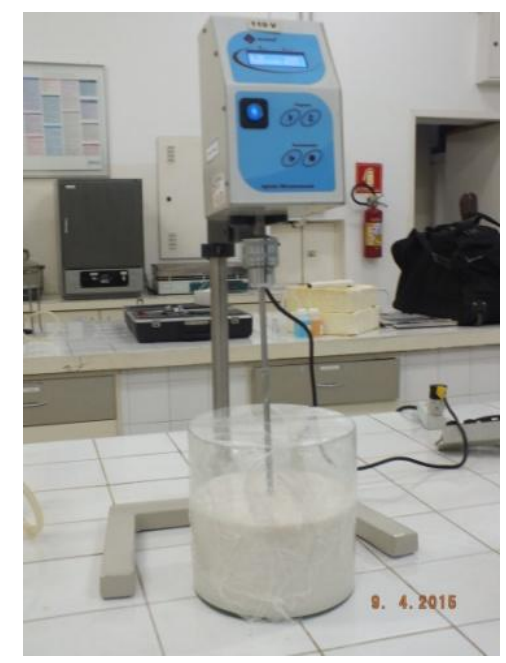

Fonte: Acervo fotográfico do autor, 2015 
Após este tempo, o adesivo formulado foi deixado em repouso por $24 \mathrm{~h}$, conforme orientações do fabricante da matéria prima polimérica. Antes desse repouso, verificou-se o $\mathrm{pH}$, cujo resultado foi de 11,25 à $21,4{ }^{\circ} \mathrm{C}$ e a viscosidade do adesivo, que teve como resultado 200 mPa.s. A medição do $\mathrm{pH}$ e da viscosidade estão apresentados nas Ilustrações 20 a e 20 b respectivamente.

Ilustração 20 a - Verificação do pH

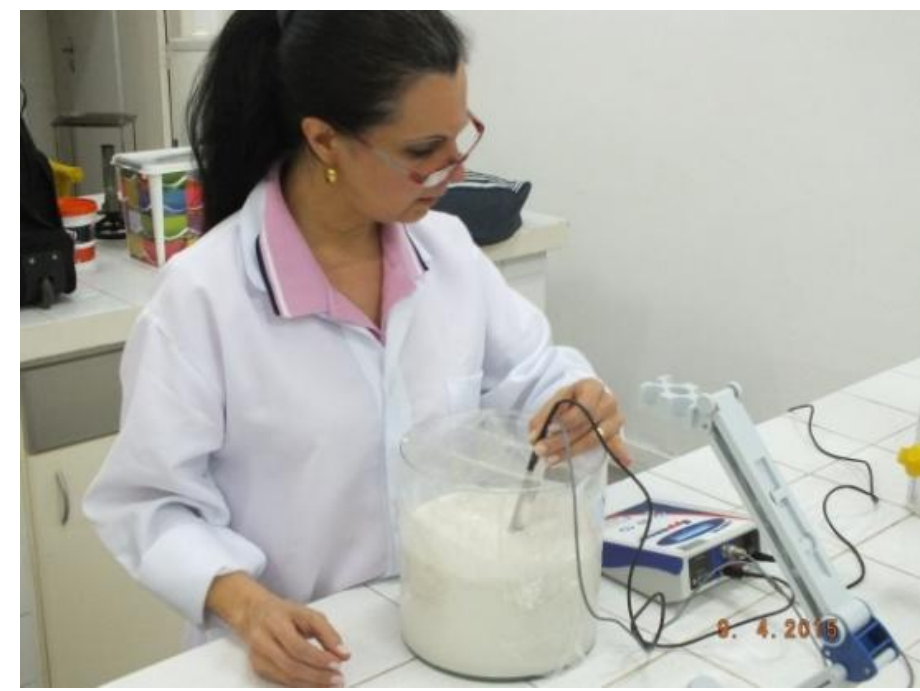

Fonte: Acervo fotográfico do autor, 2015

Ilustração 20 b - Verificação da viscosidade

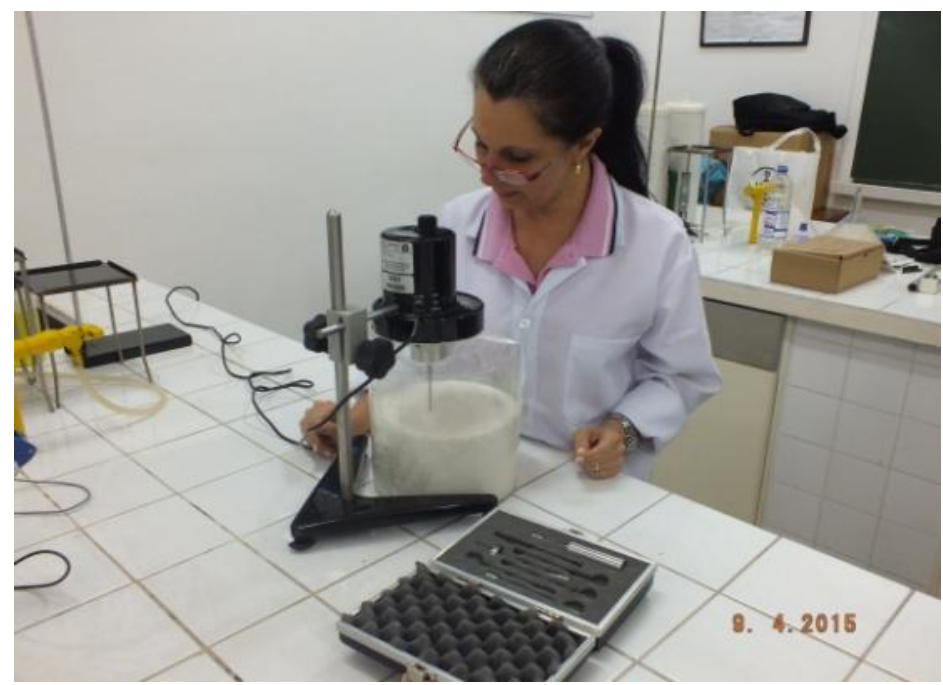

Fonte: Acervo fotográfico do autor, 2015 
Durante este período de repouso do adesivo, preparou-se a célula magnética para que no dia seguinte fosse realizado o condicionamento magnético do adesivo.

A célula magnética é composta por recipientes por onde circulará o adesivo, bombas

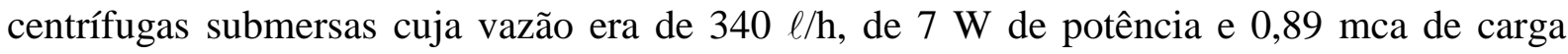
manométrica, mangueiras para transferência do adesivo, o conjunto de imãs de ferro boro neodímio, cuja intensidade do campo magnético do sistema apresentou um valor de 2120 gauss, gausímetro e misturadores apresentados, já montados na forma de utilização na Ilustração 21.

Ilustração 21 - Célula magnética

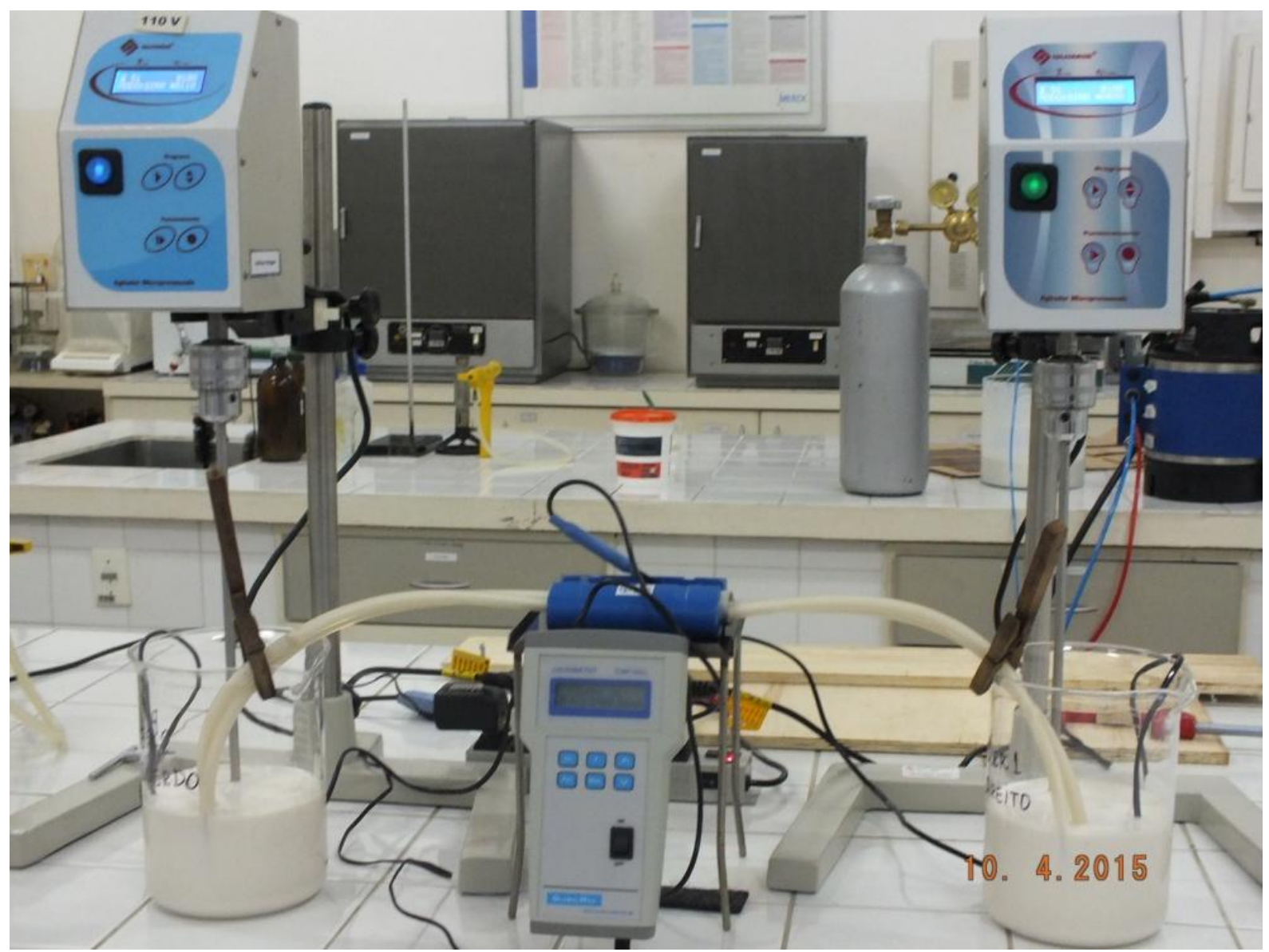

Fonte: Acervo fotográfico do autor, 2015

O condicionamento magnético consiste em um processo pelo qual o adesivo passa pelo conjunto de imãs durante $3 \mathrm{~h}$, para que a informação magnética seja passada para o adesivo. 
Enquanto o condicionamento magnético estava em andamento, outros procedimentos que não dependiam dessa etapa foram realizados.

O primeiro procedimento foi a aplicação do adesivo base água comercial e base solvente sobre os substratos.

$\mathrm{O}$ adesivo base solvente tem tempo em aberto bastante curto, ou seja, assim que se termina a aplicação do adesivo, que no caso foi feita com pincel, já foi possível proceder a união das duas partes do conjunto, ou seja, a madeira e a fórmica. Depois de aplicado o adesivo e unidas as partes de substrato, o conjunto foi submetido a pressão por alguns minutos, e somente $72 \mathrm{~h}$ após a aplicação e colagem, tempo necessário para a cura do adesivo, foi possível testar a capacidade de adesão do referido adesivo.

$\mathrm{O}$ adesivo base água comercial por sua vez, foi aplicado nos substratos, com pincel, e seu tempo em aberto foi de 45 minutos. Somente após este tempo, pôde-se unir as peças de substrato formando o conjunto colado, que também foi submetido à pressão por alguns minutos. O tempo para verificação da capacidade de adesão também é de $72 \mathrm{~h}$ após o processo de colagem terminado.

A Ilustração 22a apresenta o processo de união das peças do conjunto de substratos, após o tempo em aberto dos adesivos citados, e a Ilustração $22 b$ apresenta o processo de aplicação de pressão para fixação das peças de substrato, denominadas corpos de prova. No processo de aplicação de pressão, os corpos de prova foram enfileirados sobre a bancada e sobre eles, foi colocada uma peça de madeira, que foi posteriomente presa, para possibilitar a aplicação de pressão uniforme sobre os corpos de prova.

Ilustração 22a - União das peças de substrato

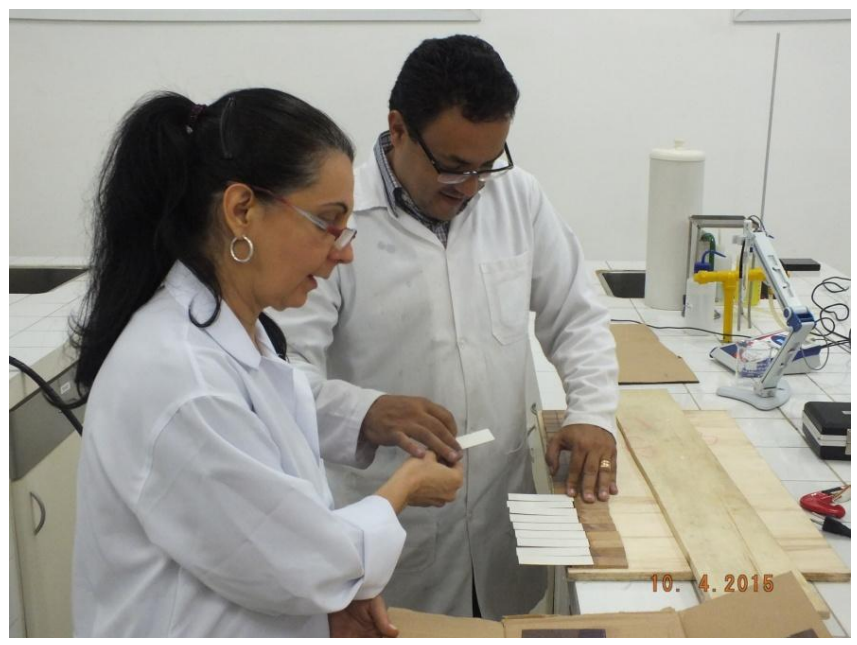

Fonte: Acervo fotográfico do autor,2015 
Ilustração 22b - Aplicação de pressão sobre os corpos de prova

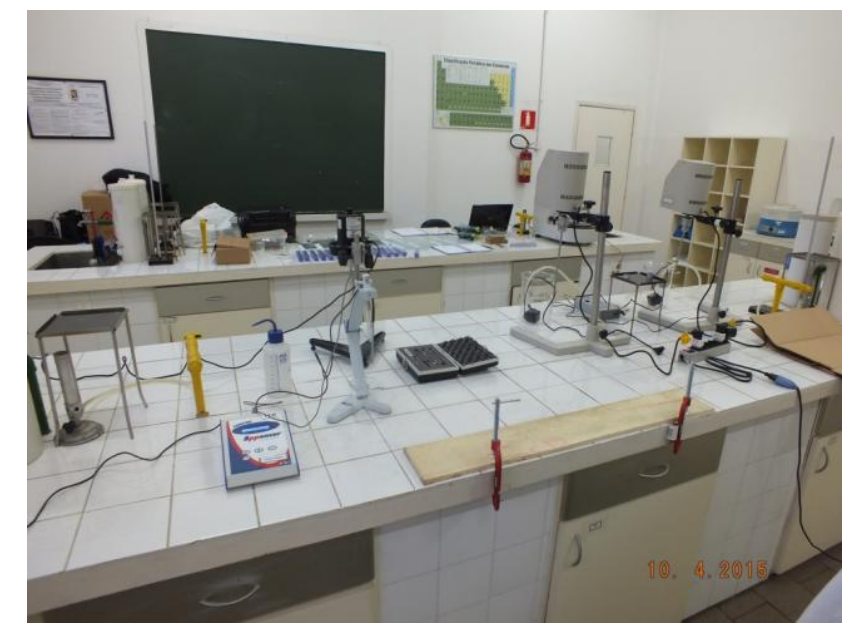

Fonte: Acervo fotográfico do autor,2015

Após o procedimento de colagem utilizando os adesivos base solvente e base água comerciais, procedeu-se o ensaio de sólidos totais do adesivo formulado para a tese.

Foram pesados os recipientes, acrescentado os adesivos, realizaram-se novas pesagens e encaminharam-se as três amostras para a estufa por 15 minutos à $180{ }^{\circ} \mathrm{C}$. Finalizado este processo, pesaram-se novamente as amostras e os resultados estão apresentados na Tabela 6.

Tabela 6 - Resultados do ensaio de sólidos totais

\begin{tabular}{ccccc}
\hline Amostras & $\begin{array}{c}\text { Tara } \\
(\mathrm{g})\end{array}$ & $\begin{array}{c}\text { Massa de } \\
\text { adesivo }(\mathrm{g})\end{array}$ & $\begin{array}{c}\text { Massa do conjunto após } \\
\text { procedimento em estufa }(\mathrm{g})\end{array}$ & $\begin{array}{c}\text { Sólidos totais } \\
\%\end{array}$ \\
\hline 1 & 7,665 & 2,033 & 8,804 & 43,97 \\
2 & 7,225 & 2,025 & 8,358 & 44,04 \\
3 & 7,615 & 2,031 & 8,752 & 44,01 \\
\multicolumn{2}{l}{ Média da \% de sólidos } & & & 44,00 \\
\hline
\end{tabular}

Após o ensaio de sólidos totais, que resultou em um valor médio de $44 \%$, preparou-se a bancada para a aplicação do adesivo formulado para a tese, que utilizou um equipamento especial, para possibilitar a aplicação na forma de spray, catalisado com gás carbônico concomitantemente à aplicação.

O equipamento de aplicação do adesivo, que foi cedido pela empresa Mapol Comércio, Importação e Exportação Ltda, é constituído por um sistema de vasos pressurizáveis, para que o adesivo seja aplicado na forma de spray, por pistola específica. 
O sistema utilizado foi um equipamento da marca Quarrata Forniture, série M1717, modelo Eco Mini, ano de fabricação 2011, composto por dois vasos pressurizáveis e uma pistola para aplicação de adesivo e gás (bicomponente), conforme apresentado nas Ilustrações 23, na qual o sistema já está acoplado ao cilindro de gás carbônico $\left(\mathrm{CO}_{2}\right)$, e 24 a e 24 b respectivamente.

Ilustração 23 - Equipamento Eco Mini

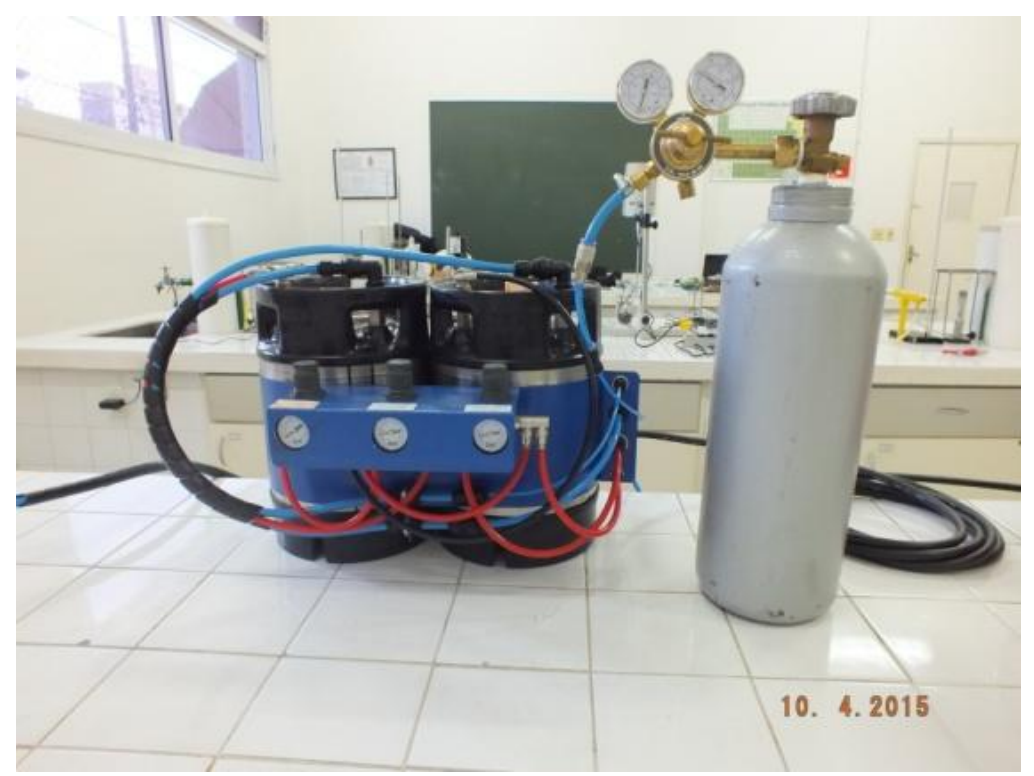

Fonte: Acervo fotográfico do autor, 2015

Ilustração 24 a - Pistola para aplicação de adesivos bicomponentes (líquido e gás)

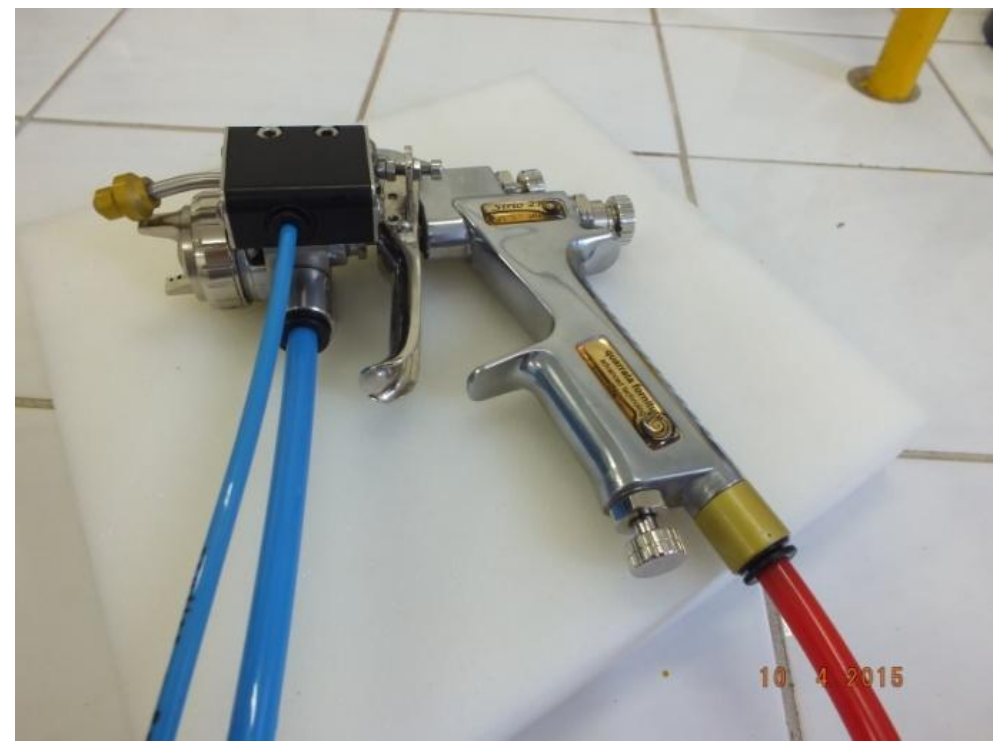

Fonte: Acervo fotográfico do autor, 2015 
Ilustração 24 b - Vista do bico de aplicação

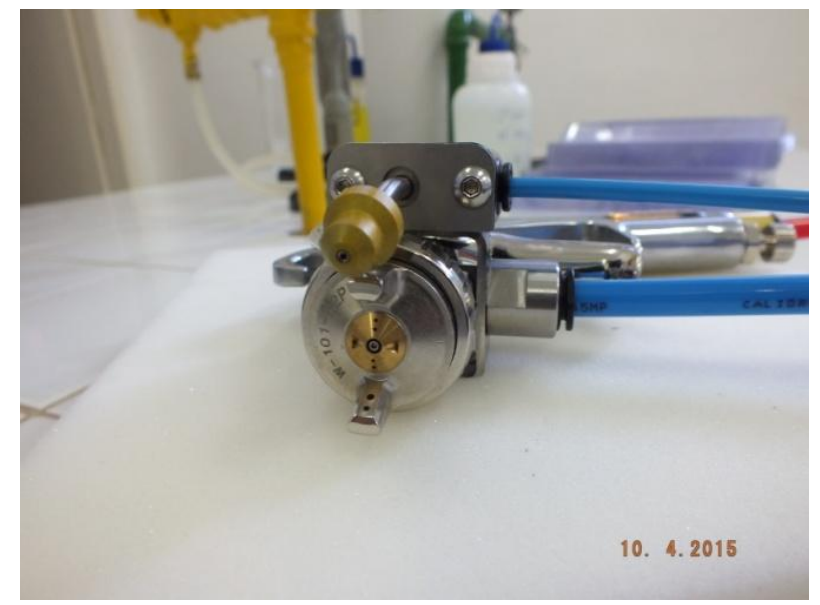

Fonte: Acervo fotográfico do autor, 2015

Para a aplicação do adesivo foi necessário acoplar ao sistema um compressor, e o conjunto ficou montado conforme Ilustração 25 .

Ilustração 25 - Montagem do sistema completo de aplicação do adesivo base aquosa catalisado com $\mathrm{CO}_{2}$

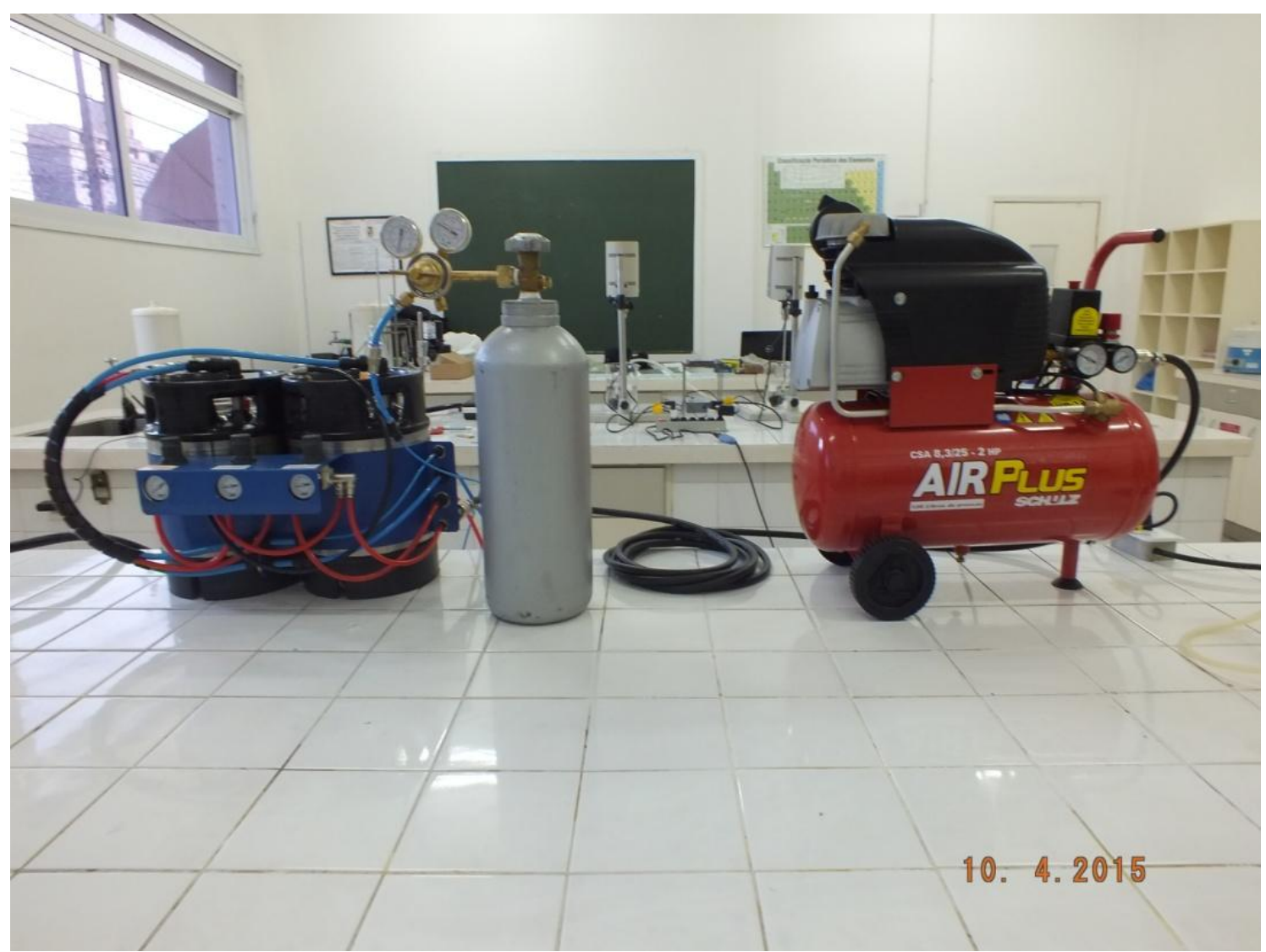

Fonte: Acervo fotográfico do autor, 2015 


\section{Descrição do procedimento de aplicação:}

Em primeiro lugar, organizaram-se as amostras e calibrou-se a quantidade de gás carbônico necessária para o processo de catálise.

Para calibrar a quantidade de gás carbônico, seguiu-se a orientação do fabricante da matéria prima, que determinou que o pH ideal de aplicação deveria ser entre 9 e 10, portanto, foram regulados os equipamentos e recolhido o spray de adesivo contendo várias quantidades de $\mathrm{CO}_{2}$ em placas de Petri, e com fitas de medição de $\mathrm{pH}$ verificaram-se os valores, até encontrar o valor ideal de $\mathrm{pH}$ da mistura adesivo $\mathrm{CO}_{2}$.

Cabe salientar que antes do condicionamento magnético, foi reservado um volume de adesivo que não foi condicionado magneticamente e no momento de aplicação, este adesivo formulado e não condicionado magneticamente apresentou um $\mathrm{pH}$ de 11,01 e viscosidade de $350 \mathrm{mPa}$.s. Procedeu-se a aplicação deste material sem condicionamento sobre os substratos, conforme representado na Ilustração 26. A área de aplicação do adesivo que foi sugerida pela empresa Brascola foi de $25 \mathrm{~mm}$ por $25 \mathrm{~mm}$. Esta empresa realizou os ensaios de tração para verificação da capacidade de adesão dos quatro universos de amostra.

Ilustração 26 - Aplicação do adesivo concomitantemente com o gás carbônico sem condicionamento magnético.

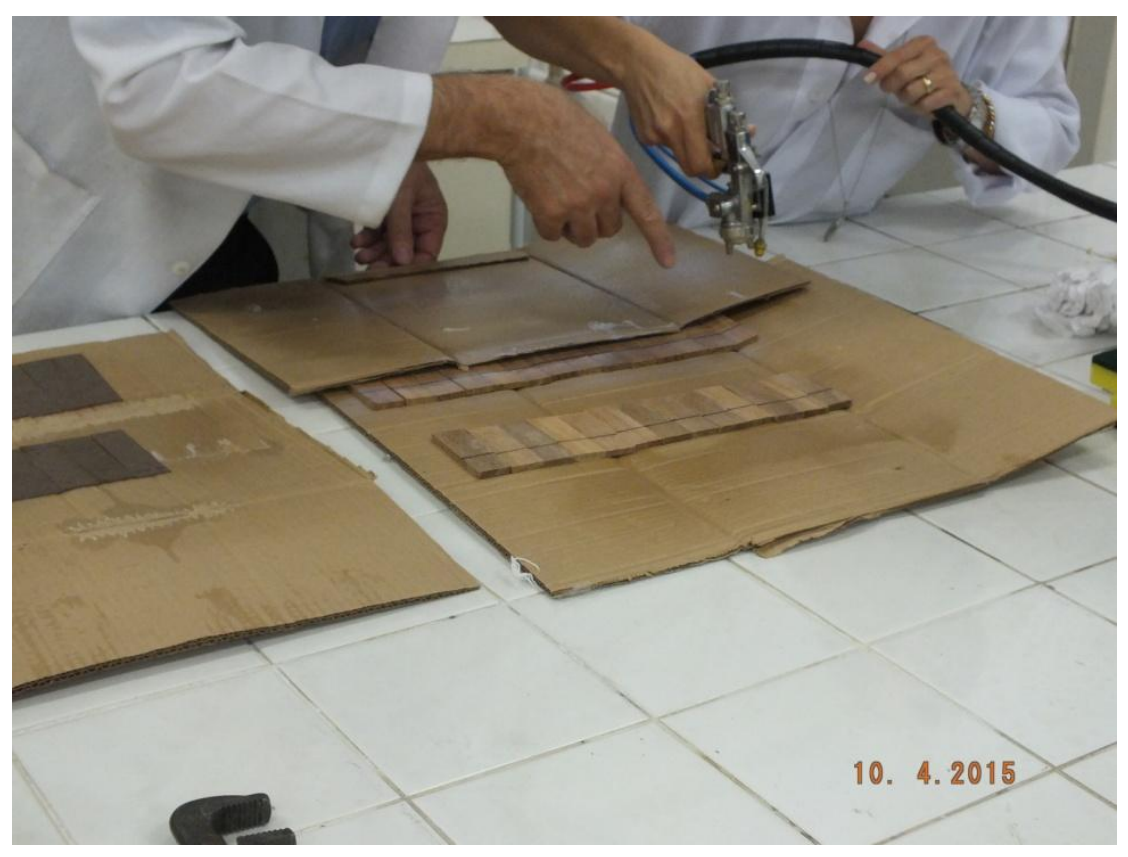


Imediatamente após a aplicação, os substratos puderam ser unidos e submetidos à aplicação de pressão por aproximadamente 5 minutos. Após $72 \mathrm{~h}$ deste procedimento, eles foram testados quanto a sua capacidade de adesão.

Durante a aplicação do adesivo formulado, conforme mencionado anteriormente, a outra porção desta mesma batelada foi submetida ao condicionamento magnético. Depois das $3 \mathrm{~h}$ de condicionamento magnético, verificou-se o $\mathrm{pH}$ do adesivo, cujo resultado foi 10, e verificou-se que a viscosidade aumentou para $1100 \mathrm{mPa}$.s. Realizou-se o mesmo procedimento de aplicação já mencionado e exemplificado pela Ilustração 25, utilizando o adesivo condicionado magneticamente.

Da mesma forma, assim que se terminou a aplicação do adesivo, pode-se fazer o procedimento de colagem, pois o tempo em aberto deste adesivo é muito curto, diferente daquele necessário para o adesivo base aquosa comercial, que era de 45 minutos.

A Ilustração 27 apresenta os substratos prontos para serem unidos após a aplicação do adesivo de policloropreno base aquosa condicionados magneticamente.

Ilustração 27 - Substratos prontos para serem colados -(fórmica à esquerda e Ipê à direita)
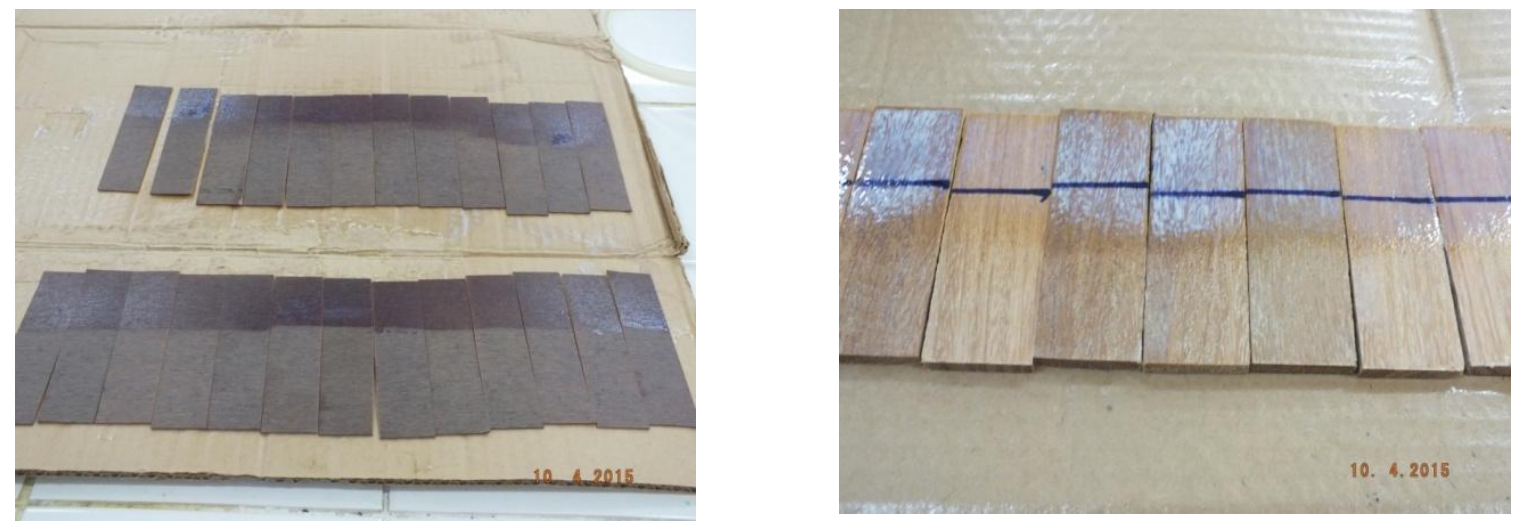

Fonte: Acervo fotográfico do autor, 2015

Desta forma, encerra-se a apresentação dos procedimentos realizados para preparar o adesivo de policloropreno base aquosa e colar os quatro grupos de amostras.

Os testes para verificação da capacidade de adesão foram realizados na Empresa Brascola, segundo normas e exigências de garantia da qualidade dos produtos.

A norma utilizada para o ensaio de cisalhamento foi a ASTM D-1002 [Standard Test Method for Apparent Shear Strength of Single-Lap-Joint Adhesively Bonded Metal Specimens by Tension Loading (Metal-to-Metal)], adaptada para o material madeira ipê com fórmica testando os grupos classificados a seguir: 
a) Grupo A1: adesivo Colabras ${ }^{\circledR}$ sem tolueno, base solvente, sem submissão ao campo magnético, lote: 14F2564, validade 30 junho 2015, viscosidade Brookfield, modelo LVR (sp 3, $10 \mathrm{rpm}$ ) igual a $2000 \mathrm{mPa} . \mathrm{s}$, teor de sólidos (estufa $180{ }^{\circ} \mathrm{C}, 15$ minutos) igual a $18,7 \%$ aplicado em madeira ipê e fórmica já curados.

b) Grupo A2: adesivo (Henkel), policloropreno, base aquosa sem submissão ao campo magnético aplicado em madeira ipê e fórmica já curados.

c) Grupo A3: adesivo (COVESTRO), policloropreno, base aquosa sem submissão ao campo magnético (SCM).

d) Grupo A4: adesivo (COVESTRO), policloropreno, base aquosa submetido ao campo magnético (CCM).

O equipamento utilizadopara a realização do ensaio de tração foi um Dinamômetro Instron, modelo 3367, com célula de carga $30 \mathrm{kN}$, apresentado na Ilustração 28.

Ilustração 28 - Dinamômetro Instron, modelo 3367

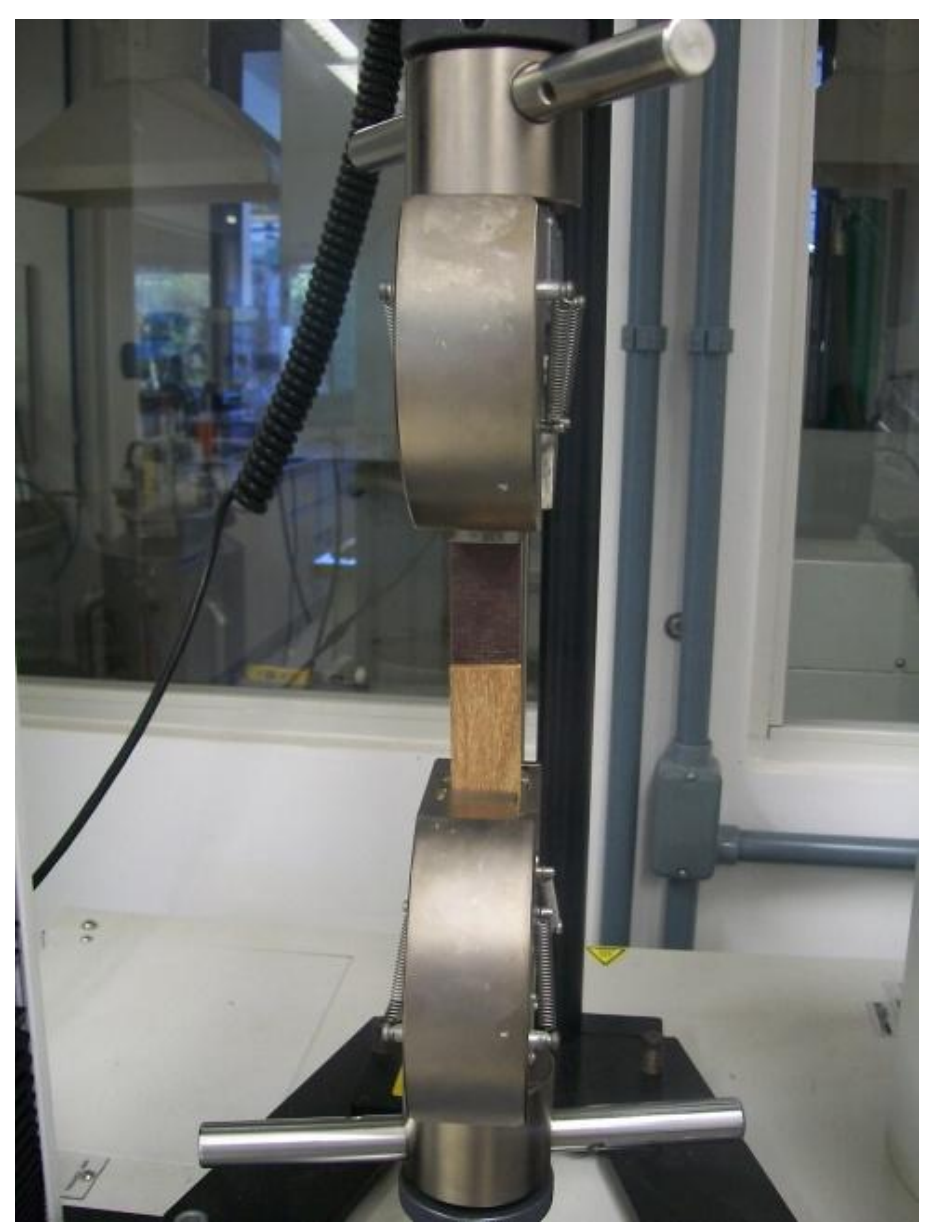

Fonte: Fotografia cedida pela empresa Brascola, 2015 


\section{RESULTADOS E DISCUSSÃO}

\subsection{VISCOSIDADE}

Em primeiro lugar observou-se que as viscosidades iniciais dos adesivos base aquosa comercial, bem como o da formulação sugerida pela COVESTRO, sem condicionamento magnético, eram de $350 \mathrm{mPa}$.s. Depois do condicionamento magnético, a viscosidade do adesivo formulado passou para $1100 \mathrm{mPa}$.s, portanto houve um espessamento significativo do adesivo base aquosa, deixando-o com a viscosidade mais próxima daquela do adesivo base solvente comercial que era de $2000 \mathrm{mPa}$.s.

O condicionamento magnético de soluções aquosas, como apresentado na literatura, organiza as estruturas moleculares, facilitando a ação das substâncias que promovem a aproximação das moléculas de polímero. Com maior viscosidade, o adesivo molha eficientemente o substrato e o filme formado não penetra muito nele, melhorando assim as condições para a adesão. A matéria-prima utilizada na formulação, como um agente espessante e, portanto, com a capacidade de aumentar a viscosidade do adesivo foi o óxido de zinco.

Quando condicionado magneticamente, o óxido de zinco tem a sua condição magnética alterada para super-paramagnética e, provavelmente, a sua reatividade no conjunto de substâncias presentes na formulação, foi aumentada. A reticulação entre as moléculas da matriz polimérica, causados pela inserção do óxido de zinco causou o aumento da viscosidade do adesivo, e como a viscosidade interfere na capacidade de adesão, tendo aumentado a viscosidade, aumentou-se por consequência, capacidade de adesão.

\subsection{TEMPO EM ABERTO}

Outro resultado interessante e desejável foi a diminuição do tempo em aberto do adesivo. No caso do adesivo base aquosa comercial, verificou-se que após a aplicação do adesivo, foi necessário esperar 45 minutos para que fosse possível fazer a colagem dos substratos, e com o adesivo formulado, catalisado com $\mathrm{CO}_{2}$ e nano aditivado, assim que foi terminada a aplicação do adesivo, os substratos já estavam em condições de serem colados. $\mathrm{O}$ tempo em aberto deste adesivo foi no máximo de 5 minutos, portanto, houve uma redução significativa do tempo aberto de adesivo. 
A teoria que embasa esta modificação no tempo em aberto está relacionada à presença de óxido de zinco e Dispercoll ${ }^{\circledR}$ S3030 na escala nanométrica, pois materiais nesta escala granulométrica podem incrementar as ligações secundárias, aumentando a intensidade dessas ligações, principalmente as de van der Waals, entre as matrizes poliméricas.

A presença, tanto do óxido de zinco como do Dispercoll ${ }^{\circledR} \mathrm{S} 3030$, favoreceram a aproximação das moléculas da matriz polimérica, possibilitando o crosslinking entre elas, o que resuta na eliminação das moléculas de água para o substrato, não sendo portanto necessário esperar a evaporação do solvente para unir os substratos.

Quando observado o comportamento do tempo em aberto dos adesivos formulados sem condicionamento magnético ( $\mathrm{SCM}$ ) e com condicionamento magnético (CCM), não houve diminuição neste tempo, ou seja, o tempo em aberto não foi alterado pelo condicionamento magnético.

É importante ressaltar que o adesivo de policloropreno base aquosa comercial não é uma preferência dos profissionais da indústria moveleira, e um dos fatores para esta rejeição é o tempo em aberto, que interfere na eficiência dos processos produtivos.

Já no caso dos adesivos formulados, catalisados com $\mathrm{CO}_{2}$ e nano aditivados, o tempo em aberto se igualou àquele do adesivo base solvente, que ainda é o mais utilizado na indústria moveleira.

\subsection{TENSÃO DE CISALHAMENTO}

Os resultados do ensaio de tração para verificação da tensão de cisalhamento suportado pelos corpos de prova são apresentados na Tabela 7. 
Tabela 7 - Resultados do ensaio de tração e tensão de cisalhamento em $\mathrm{kgf} / \mathrm{cm}^{2}$

\begin{tabular}{|c|c|c|c|c|}
\hline Corpos de Prova & $\begin{array}{c}\text { Grupo A1 } \\
\text { Base solvente } \\
\text { comercial }\end{array}$ & $\begin{array}{c}\text { Grupo A2 } \\
\text { Base aquosa } \\
\text { comercial }\end{array}$ & $\begin{array}{c}\text { Grupo A3 } \\
\text { Base aquosa } \\
\text { formulado SCM }\end{array}$ & $\begin{array}{c}\text { Grupo A4 } \\
\text { Base aquosa } \\
\text { formulado CCM }\end{array}$ \\
\hline 1 & 3,04 & 2,09 & 1,39 & 2,62 \\
\hline 2 & 5,30 & 3,75 & 1,16 & 4,77 \\
\hline 3 & 2,97 & 2,05 & 0,79 & 2,00 \\
\hline 4 & 4,52 & 2,58 & 1,21 & 2,44 \\
\hline 5 & 2,65 & 2,24 & 0,83 & 2,69 \\
\hline 6 & 3,47 & 3,36 & 0,43 & 2,07 \\
\hline 7 & 4,62 & 2,55 & 0,47 & 3,56 \\
\hline 8 & 5,21 & 4,06 & 1,32 & 3,43 \\
\hline 9 & 4,33 & 4,06 & 1,62 & 3,00 \\
\hline 10 & 3,29 & 3,40 & 1,67 & 3,27 \\
\hline 11 & 3,12 & 2,14 & 0,97 & 2,79 \\
\hline 12 & 4,83 & 2,66 & 0,54 & 4,07 \\
\hline 13 & 3,36 & 3,18 & 1,73 & 2,81 \\
\hline 14 & 2,96 & 2,35 & 0,80 & 5,42 \\
\hline 15 & 3,52 & 3,00 & 1,19 & 3,04 \\
\hline 16 & 4,00 & 3,18 & 1,02 & 5,4 \\
\hline 17 & 3,03 & 3,79 & 0,97 & 3,18 \\
\hline 18 & 2,85 & 4,36 & 0,83 & 2,24 \\
\hline 19 & 4,99 & 1,99 & 0,15 & 3,45 \\
\hline 20 & 3,06 & 2,15 & 1,25 & 2,95 \\
\hline 21 & 3,68 & 2,91 & 2,51 & 4,34 \\
\hline 22 & 2,87 & 1,29 & 2,74 & 3,13 \\
\hline 23 & 4,02 & 1,83 & 0,76 & 5,50 \\
\hline 24 & 5,35 & 1,74 & 1,65 & 2,04 \\
\hline 25 & 3,93 & 1,99 & 0,64 & 3,32 \\
\hline
\end{tabular}


Para uma melhor visualização dos dados apresentados na Tabela 7, são apresentadas as Ilustrações 29, 30 e 31.

Ilustração 29 - Resultados do ensaio de tração para os grupos A3 (COVESTRO SCM) e A4 (COVESTRO CCM)

TENSÕES DE CISALHAMENTO

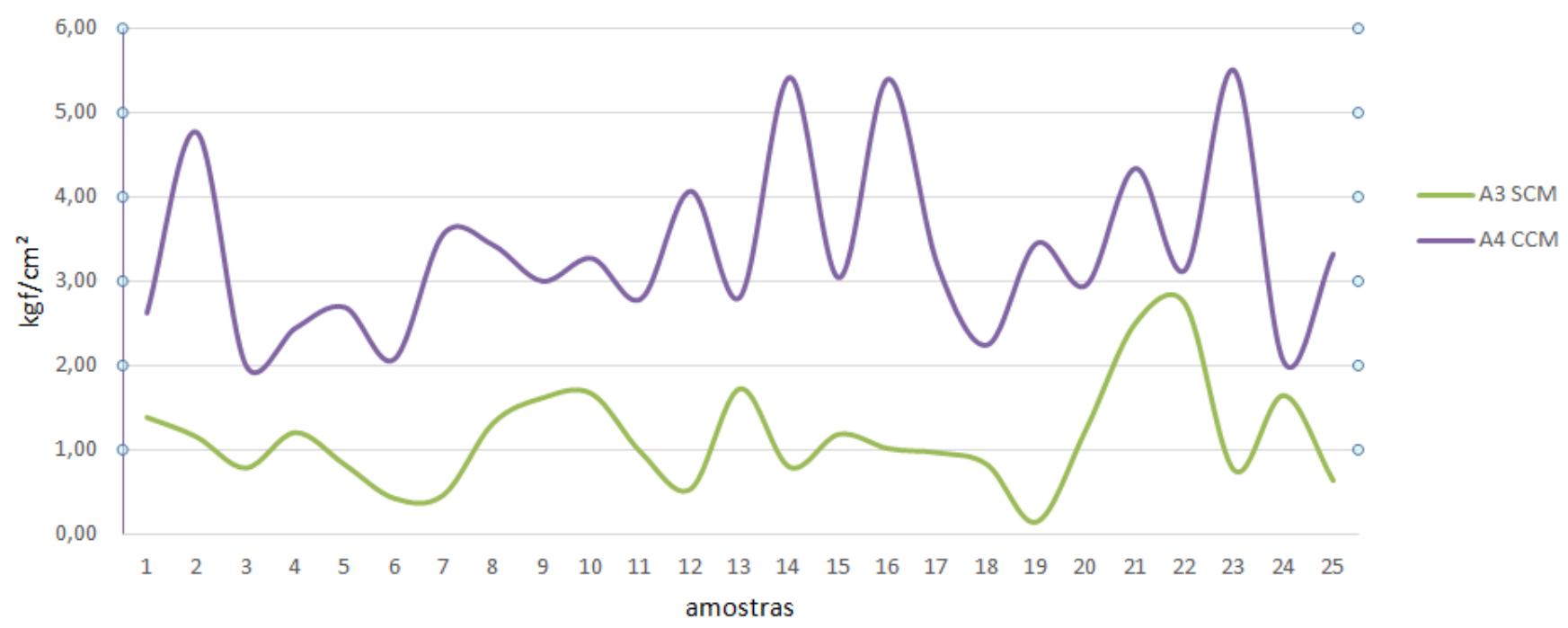

As amostras 21 e 22 do grupo A3 apresentaram um valor máximo para o ensaio de tração, valores estes que representam apenas $8 \%$ do material amostrado. Observou-se que em nenhum momento, as amostras do grupo A3 apresentaram um valor maior do que as do grupo A4 o que define uma tendência de comportamento, ou seja, o adesivo utilizado no grupo A4 foi sempre superior em capacidade de adesão do que o adesivo utilizado no grupo A3. Cabe salientar, que o adesivo utilizado no grupo A3 e o adesivo utilizado no grupo A4 são partes de uma mesma batelada de adesivo. A única diferença entre eles é o condicionamento magnético. 
Ilustração 30 - Resultados do ensaio de tração para os grupos A2 (Adesivo base aquosa Henkel), A3 (COVESTRO SCM) e A4 (COVESTRO CCM)

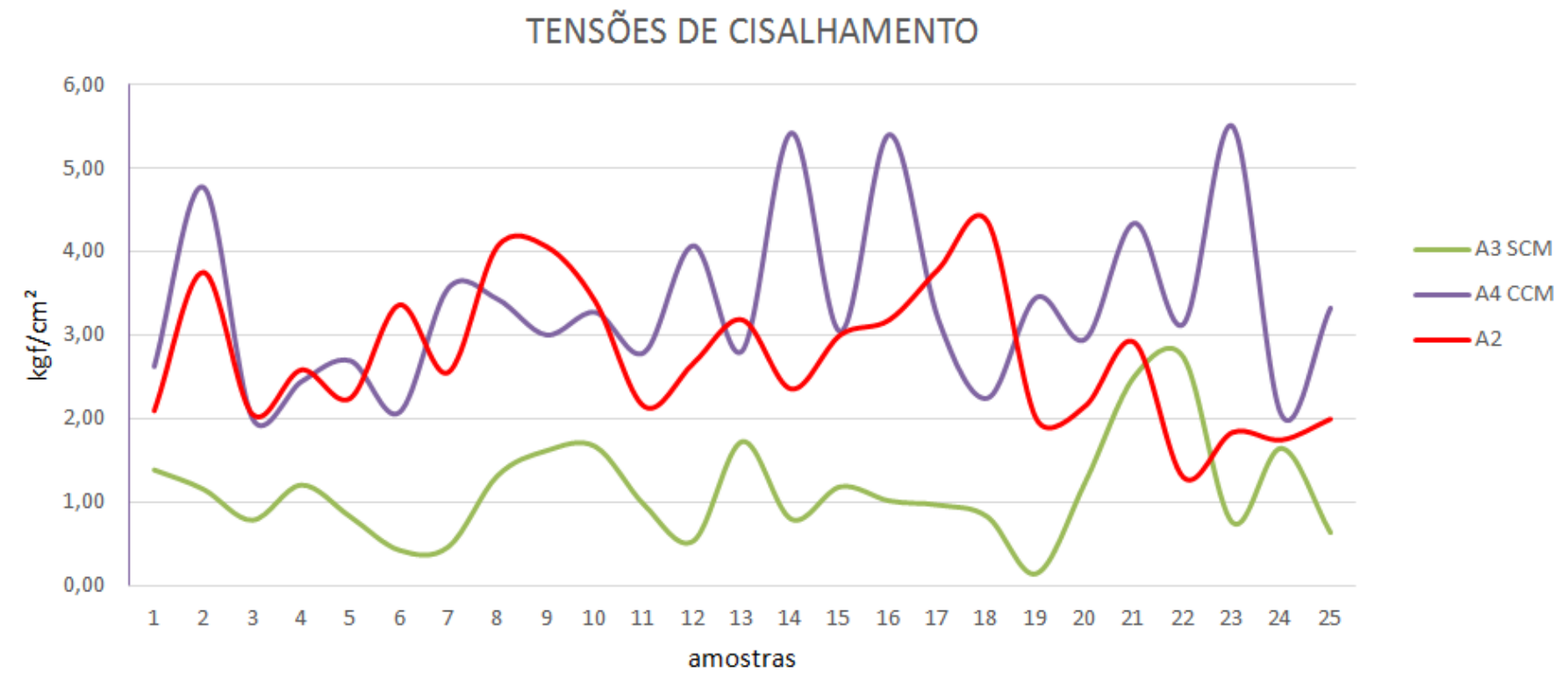

Na Ilustração 30, pode-se observar que em alguns corpos de prova, os resultados do ensaio de tração do adesivo do grupo A2 supera o adesivo do grupo A4, porém na maioria dos corpos de prova, o adesivo do grupo A4 mostra-se mais eficiente. Algumas amostras do grupo A3 com melhor desempenho tem comportamento semelhante às do grupo A2 com pior desempenho. Portanto, o grupo A3 ainda demonstra menor capacidade de adesão em relação aos grupos A2 e A4. 
Ilustração 31 - Resultados do ensaio de tração para os grupos A1 (Adesivo base solvente Colabras), A2 (Adesivo base aquosa Henkel), A3 (COVESTRO SCM) e A4 (COVESTRO $\mathrm{CCM})$

\section{TENSÕES DE CISALHAMENTO}

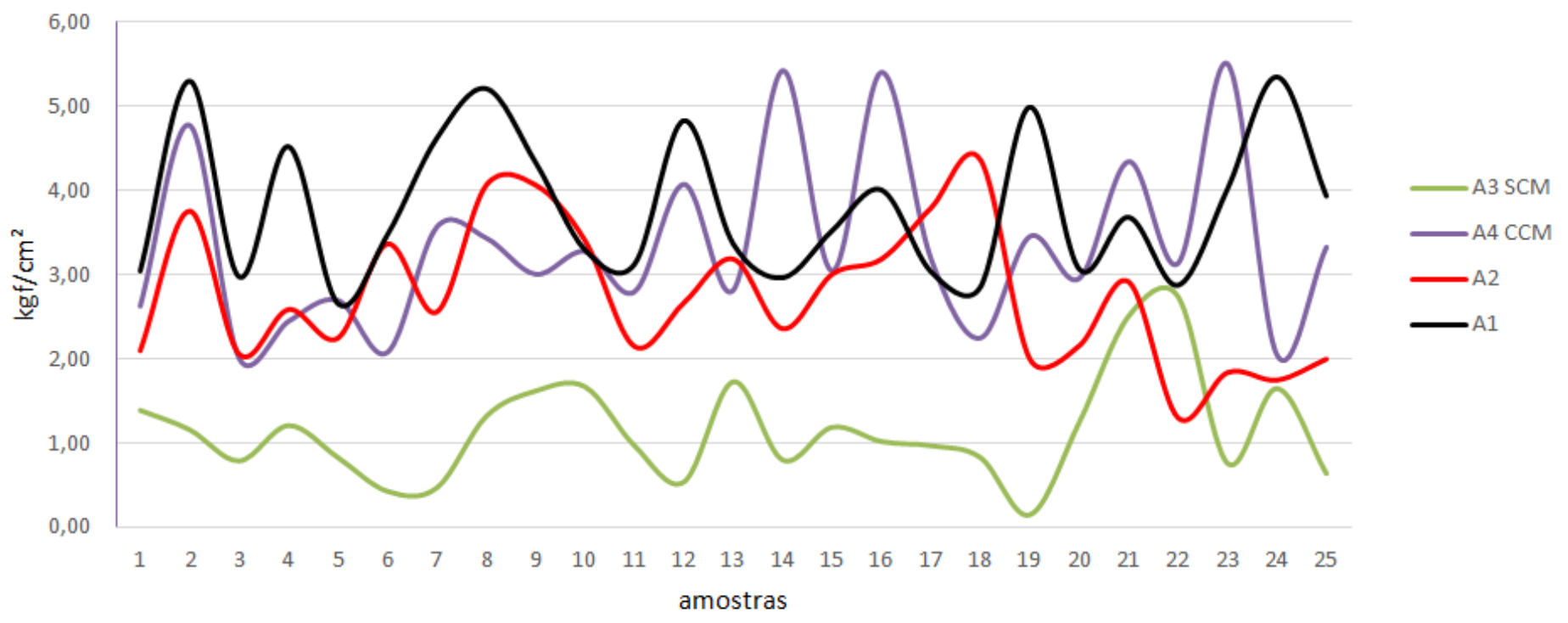

Com a ilustração 31 percebe-se que o adesivo do grupo A4 tem comportamento visualmente semelhante aos adesivos dos grupos A1 e A2 que já são comercializados, enquanto o adesivo do grupo A3 apresenta menor desempenho no que diz respeito à capacidade de adesão. 


\subsection{ANÁLISE ESTATÍSTICA DOS RESULTADOS}

Para a análise estatística dos resultados, organizou-se um novo gráfico, apresentado na Ilustração 32, no qual os resultados para cada grupo de adesivos foram organizados em forma crescente.

Ilustração 32 - Dados organizados em ordem crescente para análise estatística

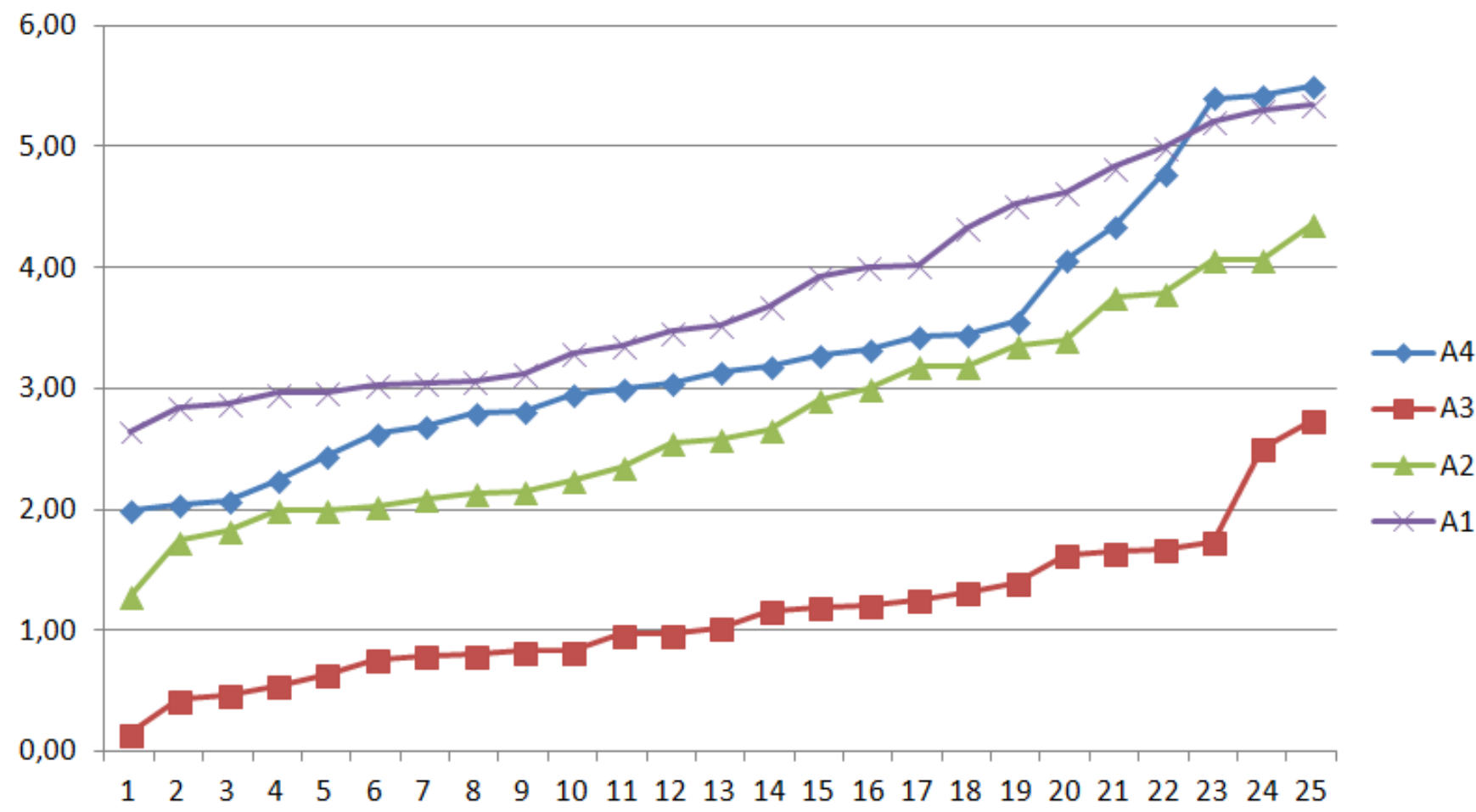

Observando-se a Ilustração 32 verifica-se uma semelhança na disposição dos dados dos quatro grupos de amostras, ou seja, não existe disparidade entre os resultados obtidos nos ensaios de tração.

Para proceder a análise dos resultados do ensaio de tração, foram utilizadas alguns conceitos da estatística, tais como, média, erro padrão, mediana, desvio padrão variância curtose e assimetria. $\mathrm{O}$ objetivo desse tratamento estatístico foi de averiguar a confiabilidade dos resultados obtidos no universo de amostras coletadas nos ensaios de tração.

A média representa o cálculo de uma tendência central e ela pode ser obtida dividindose a soma das observações pelo número de observações existentes. 
O cálculo da média é importante, pois, por meio dela, pode-se condensar uma série de dados em um único número. Um problema que pode ocorrer, às vezes, é que a média perde a sua representatividade quando, entre os números, existem valores muito diferentes um dos outros, ou alguns valores diferentes e a maioria muito próxima. Porém, para corrigir qualquer falha de interpretação de resultados, que tenha sido realizada com base apenas na média aritmética, pode-se complementar a análise estatística com a utilização de medidas de dispersão, ou seja, medidas que irão estimar a variação existente entre os valores e a média determinada. Um exemplo de medida de dispersão é o desvio padrão, ele irá descrever a dispersão de medidas individuais ao redor da média, levando em consideração a variância.

A variância por sua vez é uma medida de dispersão que mostra o quão distante cada valor desse conjunto está do valor central (médio). Quanto menor é a variância, mais próximos os valores estão da média; mas quanto maior ela é, mais os valores estão distantes da média.

O desvio padrão é capaz de identificar o "erro" em um conjunto de dados, caso fosse substituído um dos valores coletados pela média aritmética. O desvio padrão aparece junto à média aritmética, informando o quão "confiável” é esse valor.

A variabilidade das médias pode ser estimada pelo seu erro padrão. Assim, o erro padrão avalia a precisão do cálculo da média populacional levando em consideração o desvio padrão e o tamanho da amostra. Quanto melhor a precisão no cálculo da média populacional, menor será o erro padrão.

$\mathrm{Na}$ estatística e teoria da probabilidade, a mediana é o valor numérico que separa a metade superior de uma amostra de dados, população ou distribuição de probabilidade, em rol ordenado de forma crescente ou decrescente, a partir da metade inferior.

A curtose por sua vez é uma medida de dispersão que caracteriza o pico ou "achatamento" da curva da função de distribuição de probabilidade. Alguns textos definem a curtose como a razão entre o quarto momento central e o quadrado do segundo momento central. A curtose não tem limite superior (ou seja, existem distribuições com curtose tão alta quanto se queira), porém seu limite inferior é -2.

Se o valor da curtose for igual a 0 (ou 3, pela segunda definição), então tem o mesmo achatamento que a distribuição normal. Chamam-se estas funções de mesocúrticas.

Se o valor da curtose é maior do que zero 0 (ou > 3), então a distribuição em questão é mais alta (afunilada) do que a distribuição normal e é chamada de leptocúrtica, ou que a distribuição tem caudas pesadas, e se o valor da curtose é menor do que zero (ou < 3), então a 
função de distribuição é mais "achatada" que a distribuição normal e denominada de platicúrtica.

Os resultados dessa análise estatística estão apresentados na Tabela 8.

Tabela 8 - Resultados das análises estatísticas

\begin{tabular}{lcccc}
\hline & Grupo A1 & Grupo A2 & Grupo A3 & Grupo A4 \\
\hline Média & 3,80 & 2,75 & 1,15 & 3,34 \\
Erro Padrão & 0,17 & 0,17 & 0,12 & 0,21 \\
Mediana & 3,52 & 2,58 & 1,02 & 3,13 \\
Variabilidade & 0,23 & 0,30 & 0,53 & 0,31 \\
Desvio padrão & 0,87 & 0,83 & 0,61 & 1,04 \\
Variância & 0,75 & 0,70 & 0,37 & 1,08 \\
Curtose & $-1,10$ & $-0,87$ & 1,28 & 0,03 \\
Assimetria & 0,53 & 0,35 & 1,00 & 0,90 \\
Intervalo & 2,70 & 3,07 & 2,59 & 3,50 \\
Mínimo & 2,65 & 1,29 & 0,15 & 2,00 \\
Máximo & 5,35 & 4,36 & 2,74 & 5,50 \\
Soma & 94,97 & 68,67 & 28,64 & 83,53 \\
Contagem & 25,00 & 25,00 & 25,00 & 25,00 \\
\hline
\end{tabular}

Com as análises estatísticas, pôde-se concluir que existe confiabilidade na amostragem, principalmente, levando em conta que o processo de aplicação é manual e os substratos são materiais naturais, com suas diferentes constituições referentes ao crescimento da madeira, portanto com superfícies diferentes no que diz respeito à molhabilidade e ancoragem do adesivo. Os valores mais elevados de dispersão podem estar atrelados a estes fatores.

Porém, o resultado que é o mais utilizado na prática industrial é aquele que compara diretamente os universos em relação às suas médias, e neste caso, tem-se que o adesivo de policloropreno base aquosa condicionado magneticamente tem uma capacidade de adesão $292 \%$ maior que a base aquosa sem condicionamento magnético, $122 \%$ maior que o adesivo base aquosa comercial e $12 \%$ menor que o adesivo base solvente comercial, o que é um resultado surpreendente no que diz respeito a utilização do campo magnético como elemento de diferenciação na formulação do adesivo. Esta comparação entre os resultados pode ser observada na Ilustração 33. 
Ilustração 33 - Resultados comparativos do ensaio de tração para os grupos A1 (Adesivo base solvente Colabrás), A2 (Adesivo base aquosa Henkel), A3 (COVESTRO SCM) e A4 (COVESTRO CCM)

Tensões de Cisalhamento $\left(\mathrm{kgf} / \mathrm{cm}^{2}\right)$

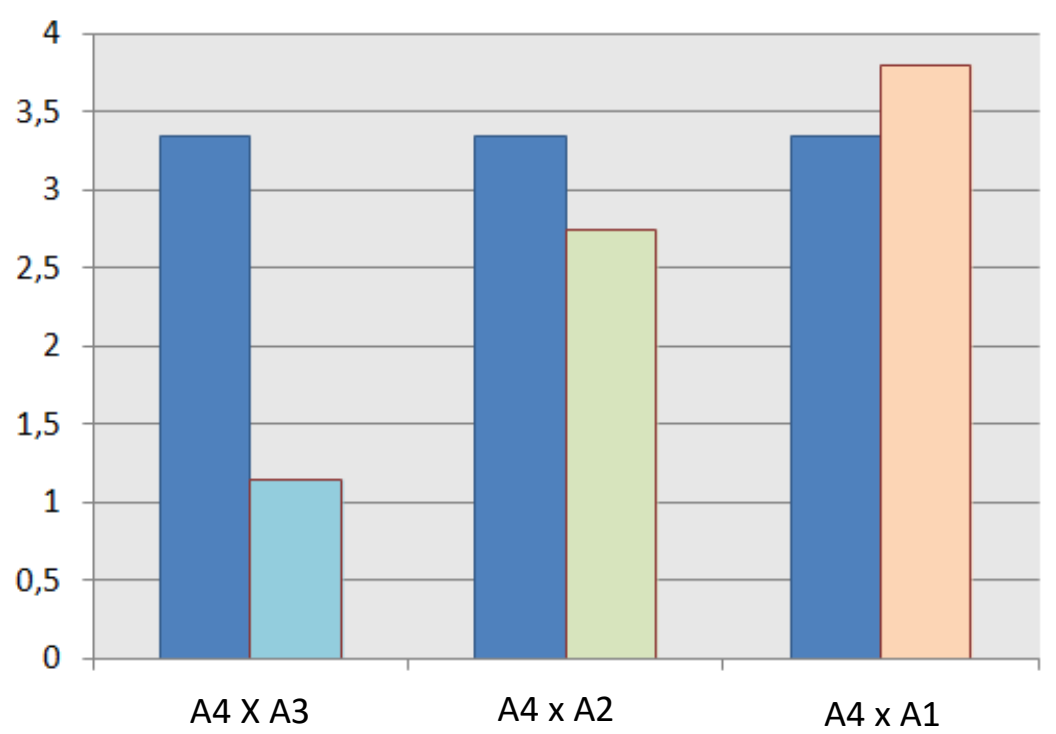

Com a intenção de apresentar um resumo dos resultados obtidos em função das variáveis estudadas, apresenta-se Ilustração 34.

Ilustração 34 - Resultados obtidos em função das variáveis estudadas

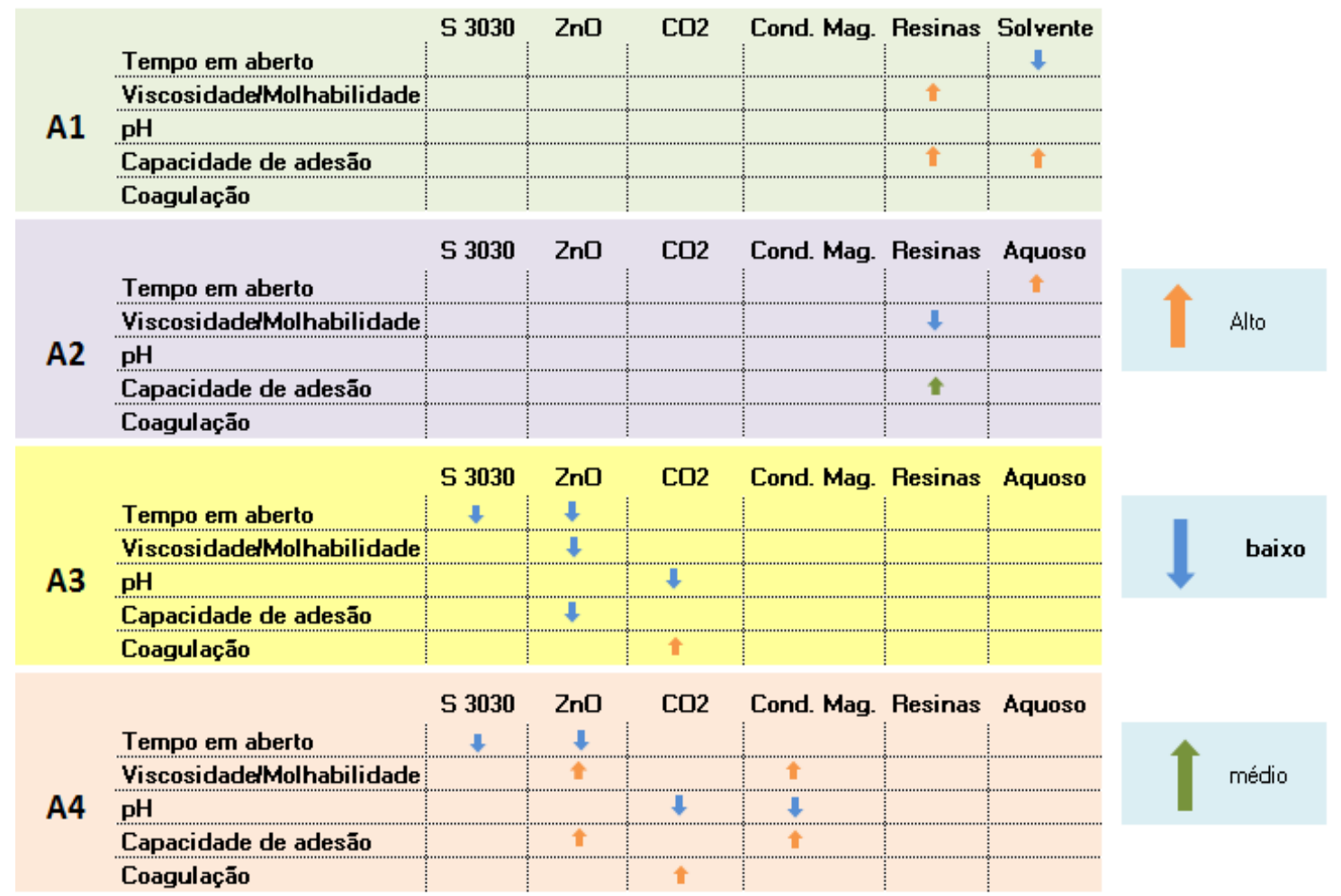


Analisando o grupo A1, observa-se que o tempo em aberto é baixo, devido à presença de solvente orgânico na formulação. A viscosidade é elevadapois na formulação foi adicionadas resinas, que também contribuíram na elevada capacidade de adesão.

No grupo A2, observa-se que a viscosidade não é elevada, o que interfere na capacidade de adesão, tornando-a menor quando comparada com o grupo A1. O tempo em aberto é alto, pois utiliza água como solvente.

O adesivo utilizado nos grupos A3 e A4 têm uma formulação diferenciada, utilizando o Dispercoll ${ }^{\circledR}$ S3030 e o óxido de zinco na escala nanométrica, que em conjunto, atuaram na redução do tempo em aberto, como já discutido. Em ambos dos grupos, foi utilizado o $\mathrm{CO}_{2}$ como catalisador durante o processo de aplicação, o que ajudou a reduzir o $\mathrm{pH}$ do adesivo formulado, deixando no $\mathrm{pH}$ ideal para a aplicação.

Pode-se observar que a capacidade de adesão do grupo A3 foi a menor dentre os quatro grupos estudados, levando a considerar que para esta formulação seria necessário a utilização de resinas para aumento da viscosidade, promovendo assim uma possível melhora na capacidade de adesão.

O grupo A4 apresentou um aumento na viscosidade quando submetido ao condicionamento magnético, o que interferiu positivamente na capacidade de adesão. 


\section{CONCLUSÕES}

Apresentou-se um referencial teórico atualizado sobre a teoria da adesão, com a finalidade de embasar o desenvolvimento desta pesquisa, para que se pudessem realizar observações e análises consistentes e não inferenciais.

Com base nesta teoria, verificou-se que a aditivação da matriz polimérica, utilizando antioxidante e espessante na escala nanométrica, juntamente com um sistema de catálise concomitante de $\mathrm{CO}_{2}$, resultou na redução do tempo em aberto do adesivo de policloropreno base água de 45 minutos para 5 minutos, resolvendo um problema de falta de eficiência de produção, que faz com que o adesivo de policloropreno base água não seja preferido pelos profissionais da área.

Embora o óxido de zinco utilizado seja uma matéria prima de custo alto, a quantidade deste componente na formulação é reduzida, o que não causa impacto no custo final do produto acabado.

A teoria que embasa esta modificação no tempo em aberto está relacionada à presença de óxido de zinco na escala nanométrica, e conforme já descrito, materiais nesta escala de granulometria podem atuar nas ligações secundárias, aumentando a intensidade dessas ligações, de van der Waals principalmente, entre as matrizes poliméricas, incrementando-as, não necessitando do tempo de evaporação do solvente tão abrangente, como aquele da formulação sem este tipo de aditivo.

A utilização do gás carbônico como catalisador foi muito interessante, pois em se tratando de um adesivo base aquosa, com a inserção do $\mathrm{CO}_{2}$, houve a formação de ácido carbônico, que reduziu o pH da formulação, deixando-o no ponto ideal para a adesão. Pelos resultados obtidos, o pH do adesivo formulado era de 11, valor este não ideal para proceder-se a colagem com um tempo em aberto menor. Com o gás carbônico, o pH diminuiu para 10, devido a interação entre o gás carbônico e a água presente na formulação, formando ácido carbônico, o que já proporcionou um estado ideal para a diminuição do tempo em aberto e possibilidade de adesão. Porém, notou-se que esta formulação não atingiu uma capacidade de adesão tão eficiente como as demais.

Esta formulação só se mostrou eficiente após o condicionamento magnético, que gerou alteração significativa da viscosidade, cuja variação foi de $350 \mathrm{mPa} . \mathrm{s}$ para $1.100 \mathrm{mPa}$.s, sem que fosse necessário adicionar nenhum espessante extra e o $\mathrm{pH}$ variou para 12.

Em laboratório, já haviam sido realizados experimentos com o borbulhamento de $\mathrm{CO}_{2}$ diretamente no recipiente contendo adesivo já formulado e posteriormente aplicado com uma 
pistola tradicional, com apenas um bico de aplicação. Este processo mostrou-se ineficiente, pois com a presença do catalisador, o adesivo começava seu processo de coagulação dentro do equipamento de aplicação, o que causava dificuldades para aplicá-lo.

Foi sugerido pela empresa que produz a matriz polimérica, que se utilizasse um sistema de aplicação do adesivo base aquosa bi-componente, para resolver o problema do entupimento da pistola. No Brasil, ainda não existe uma empresa que produza este tipo de equipamento, então foi necessário realizar uma pesquisa entre os importadores de equipamentos de aplicação de adesivo base aquosa até encontrar um equipamento que servisse para o intento desse trabalho, que foi o equipamento Eco Mini já descrito.

Este sistema de aplicação mostrou-se de manuseio fácil e no processo de aplicação do adesivo notou-se que se utilizou uma quantidade muito menor de adesivo, quando comparado com o adesivo base água aplicado por pincel. Ou seja, obteve-se com este sistema, um rendimento melhor do produto, fato este de importância relevante, pois na formulação, utilizaram-se matérias primas de tecnologia de produção alta, como por exemplo, as matrizes poliméricas e o óxido de zinco na escala nanométrica, que poderiam impactar no custo final do produto. A utilização do gás carbônico como catalisador também tem importância no custo do produto final, além do que, não causa aspectos e impactos ambientais na sua produção e utilização durante a sua aplicação.

No que diz respeito à capacidade de adesão, ficou evidente que foi possível incrementar esta capacidade com o condicionamento do adesivo de policloropreno base aquosa, pois comparando os resultados do ensaio de tração dos quatro grupos de amostra, conseguiu-se aproximar o resultado da capacidade de adesão de um adesivo base água com um adesivo base solvente, evento não observado entre o adesivo base aquosa e base solvente comerciais. Dos adesivos base aquosa, aquele condicionado magneticamente, foi o que apresentou capacidade de adesão melhor.

Comparando-se apenas os adesivos de mesma formulação, condicionado magneticamente e não condicionado, o incremento na capacidade de adesão foi de $292 \%$, resultado muito além do esperado, ressaltando-se que não houve nenhuma inserção de outra matéria prima para melhorar esta característica do adesivo. O tempo em aberto para estes dois grupos de amostra não sofreu variação significativa, mas apresentou resultado muito significativo, quando comparado com o adesivo base aquosa comercial. 


\section{CONSIDERAÇÕES FINAIS}

Como contribuição para trabalhos futuros, sugere-se elaborar formulações com outras granulometrias de óxido de zinco e materiais que possam substituir o Dispercoll ${ }^{\circledR}$ S3030, para verificação da influência dessa característica no tempo em aberto.

A utilização de outras matérias primas, como resinas, podem ser inseridas, para verificar se há aumento na capacidade de adesão.

Além disso, pode-se condicionar magneticamente adesivos formulados com outras matrizes poliméricas e famílias de nanoaditivos diferentes, para observação das alterações das capacidades de adesão, tempo em aberto e viscosidade. 


\section{REFERÊNCIAS}

ABIQUIM ASSOCIAÇÃO BRASILEIRA DA INDÚSTRIA QUÍMICA. Estatística do segmento de colas, adesivos e selantes. Equipe de economia e estatística. São Paulo, v.10. n.1. 19 p, 2011.

ACHTEN, D.; KUEKER, P.; KEMPKES, J.; LORENZ, B.; MATNER, M.; JESKE, W.; COLINAS-MARTINEZ, J. Patente CA 2735849, 2009.

Disponível em: http://www.google.es/patentes/CA 2735849. Acesso em: 10.ago.2014.

ALEKSANDROV, V.D.; BARANNIKOV, A. A.; DOBRITSA, N. V. Effect of magnetic field on the supercooling of water drops. Inorganics Materials (Translation of Neorganicheskie Materialy). v.36. 875 p. 2005.

ANACHKOV, M. P.; RAKOVSKY, S. K.; STEFANOVA, R. V.; STOYANOV, A. K. Ozone degradation of polychloroprene rubber in solution. Polymer Degradation and Stability, v. 41, p. 185-190, 1993.

ASTM INTERNATIONAL. ASTM D-1002: Standard Test Method for Apparent Shear Strength of Single-Lap-Joint Adhesively Bonded Metal Specimens by Tension Loading (Metal-to-Metal). West Conshohocken, PA, 2010. Disponível em www.astm.org.

BARBOZA, M. A. Ação de campos magnéticos em alguns sistemas químicos e biológicos. 2002. 144p. Dissertação (Mestrado) Universidade de Campinas, UNICAMP, Campinas, 2002.

BEAUGNON, E.; TOURNIER, R. Magnetically controlled convection in a paramagnetic fluid. Nature, n.3, p. 349, 470, 1991.

BELOVA, V. Magnetic treatment of water. Soviet Science Review: Scientific Developments In the USSR, n. 3, p. 150-156, 1972.

BORRACHA ATUAL. Disponível em: www.borrachaatual.com.br. Acesso em: 25 nov. 2007.

BRANLARD, P.; PARISOT, J. Policloropreno, estrutura e propriedades. Rhone-Poulenc do Brasil.[198-?].

BUENO, W. A. Ligação de hidrogênio. São Paulo: Ed. Mcgraw-Hill Do Brasil LTDA, 1978. $181 \mathrm{p}$.

CAMPOS, C. I.; LAHR, F. A. R. Estudo Comparativo dos Resultados de Ensaio de Tração Perpendicular para MDF Produzido em Laboratório com Fibras de Pinus e de Eucalipto Utilizando Uréia-Formaldeído. Matéria Revista, Rio de Janeiro, v. 9, p. 32 - 42 , 2004. 
CANEVAROLO JÚNIOR, S.V. Ciência dos polímeros: Um texto básico para tecnólogos e engenheiros. 3. ed. São Paulo: Artliber Editora Ltda, 2013. 280 p.

CHEMICAL ABSTRACTS. subject: Magnetic Water,1990-2000.

DELOR, F.; LACOSTE, J.; LEMAIRE, J.; BARROIS-OUDIN, N.; CARDINET, C. Photoand thermal ageing of polychloroprene: Effect of carbon black and crosslinking. Polymer Degradation and Stability, v. 53, p. 361-369, 1996.

DISPERCOLL ${ }^{\circledR} \mathrm{C}$ 74. Product Datasheet. . Editor: Coatings, Adhesives \& Specialties. Bayer Materialscience AG. D-51368. Leverkusen, Germany. 2013. Disponível em: www.materialscience.bayer.com. Acesso em: 10 ago. 2014.

DISPERCOLL ${ }^{\circledR}$ C VPLS 2325. Product Datasheet. . Editor: Coatings, Adhesives \& Specialties. Bayer Materialscience AG. D-51368. Leverkusen, Germany, 2013. Disponível em: www.materialscience.bayer.com. Acesso em: 10 ago. 2014.

DISPERCOLL ${ }^{\circledR}$ C VPLS 2372/1. Product Datasheet. . Editor: Coatings, Adhesives \& Specialties. Bayer Materialscience AG. D-51368 Leverkusen, Germany, 2013. Disponível em: www.materialscience.bayer.com. Acesso em: 10 ago. 2014.

DISPERCOLL ${ }^{\circledR}$ C 84. Product Datasheet.. Editor: Coatings, Adhesives \& Specialties. Bayer Materialscience AG. D-51368 Leverkusen, Germany, 2013. Disponível em: www.materialscience.bayer.com. Acesso em: 10 ago. 2014.

DISPERCOLL ${ }^{\circledR}$ S 3030. Product Datasheet. Editor: Coatings, Adhesives \& Specialties. Bayer Materialscience AGD-51368 Leverkusen, Germany. 2013, Disponível em: www.materialscience.bayer.com. Acesso em: 10 ago. 2014.

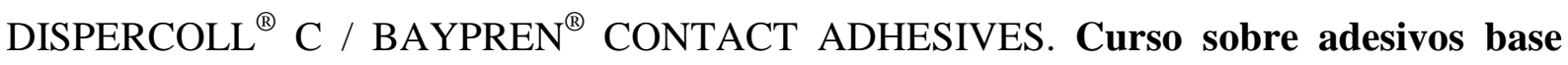
aquosa. Winfried Jeske, 2014.

DURÁN, N.; MATTOSO, L. H. C.; MORAIS, P. C. Nanotecnologia: Introdução, preparação e caracterização de nanomateriais e exemplos de aplicação. 1. ed. São Paulo: Artliber Editora Ltda, 2006. 208 p.

FAIGLE, J. F. G. ; PORTO, M. E. G. Evidências de alterações de comportamento da água quando submetida a campos magnéticos. In: Congresso Brasileiro: A Homeopatia no Século XXI, Campinas, SP, 2000. Anais, 2000.

FLEICHMANN, W.; GARNICH, F.; LENNOX, A.; MAYER, W.; COCCO, J.; FORGACH, A. D. ; HEATON J. J. ; McNICKLE J. A.; NOLAN, D. A.; O’REILLY, C.; PERKINS, J. G. 
Loctite Worldwide Design Handbook. Loctite North America. Connecticut, USA: Rocky Hill, 1997. 463p.

FOTEA, C.; D'SILVA, C. Adhesion enhancement of chromium tanned heavyduty leather (Salz leather) under extreme conditions using photoreagents as surface primers. International Journal of Adhesion and Adhesives, vol. 25, p. 442-449, 2005.

FREITAS, A. M. B. Influência do campo magnético na cristalização em solução, Dissertação de mestrado Universidade Federal de São Carlos (UFSCAR). São Carlos, 1999.

GALEMBECK, F.; GANDUR, M. C. Adesão de superfícies. Curso aberto. São Carlos, ABPol, 1995.

GEHR, R., ZHAI, Z.A., FINCH, J.A., RAO, S.R. Reduction of soluble mineral concentrations in CaSO4 saturated water using a magnetic field. Water Research, v. 29, n. 3, p. 933-940, 1995.

HANDBUCH FUER DIE GUMMIINDUSTRIE. Bayer AG, Leverkusen,1992. cap. 4.

INTERNATIONAL STANDARD -ISO 472 : Plastic vocabulary. 3. ed., 1999.

JOSHI, K. M., AND P. V. KAMAT. Effect of magnetic field on the physical properties of water. J. Ind. Chem. Soc., v.43, p. 620-622, 1966.

KARAČ A. Testing adhesives and adhesively bonded joints. Workbook. Universidade de Zagreb, 2008.

KATSUKI, A.; TOKUNAGA, R.; WATANABE, S.; TANIMOTO, Y. The Effect of High Magnetic Field on the Crystal Growth of Benzophenone. Chem. Lett., v.8, p. 607, 1996.

KRONENBERG, J. K. Magnetic Water Treatment Demystified Magnets, Claremont, CA , USA, p. 6 - 15, 271987.

KRONENBERG, J. K. Magnetized II: More alluring facts about treating water with magnets. Magnetized, Aqua Magazine, p. 20-24, 1993.

LATINCOAT \& ADHESIVES. CONGRESSO DE TECNOLOGIA E GESTÃO EM TINTAS, DESIVOS E QUÍMICOS PARA CONSTRUÇÃO, 6, 2012. Porto Alegre, Anais.

LANDGRAF, F. J. G.; GARCIA, P. M. P.; POÇO, J. G.; GIULIETTI, M. Efeito do campo magnético em soluções aquosas. In: CONGRESSO BRASILEIRO DE ENGENHARIA E CIÊNCIA DOS MATERIAIS, 16., Porto Alegre, 2004. CBCIMAT. Porto Alegre, PUCRS, 2004. 
LAZARENKO, L. N.; ZHURAVLEV, P. D. 1985. apud GEHR, R., ZHAI, Z.A., FINCH, J.A., RAO, S.R. Reduction of soluble mineral concentrations in CaSO4 saturated water using a magnetic field. Water Research, v. 29, n. 3, p. 933-940, 1995.

LIESA, F.; BILURBINA, L. Adhesivos Industriales, Barcelona, Espanha: Marcombo S.A, 1990.

MARTÍNEZ-GARCIA, A.; SÁNCHEZ-RECHE, A.; MARTÍN-MARTÍNEZ, J. M. Adhesion of surface-treated EVA to polychloprene adhesive containing different polyisocyanate content. International Journal of Adhesion and Adhesives, vol. 25, p.201-209, 2005.

MARTINS, A. F.; NAPOLITANO, B. A., VISCONTE, L. L. Y., NUNES, R. C. R.FURTADO, A. M. Propriedades Mecânicas e Dinâmico-mecânicas de Composições de Policloropreno com Negro de Fumo. Polímeros, v. 12, n. 3, 2002.

MAYRINCK, C.; RAPHAEL, E.; FERRARI, J. L.; SCHIAVON, M. A. Síntese, Propriedades e Aplicações de Óxido de Zinco Nanoestruturado. Rev. Virtual Quim, n.6, p.1185-1204, 2014. Data de publicação na Web: 7 de outubro de 2014.

MORGAN,J.; WARREN, B.E. X-Ray Analysis of the Structure of Water . J. Chem. Phys., v.6, p. 666, 1938.

MUSCH, R.; MANAZEK, J.; PERREY, H.; PANSKUS, K. Patente US 7659338, 2010. Disponível em: http://www.google.es/patents/US7659338. Acesso em: 10. ago. 2014.

MUSCH, R.; PANSKUS, K.; STEINRT, A. Patente US 7354971, 2008. Disponível em: http://www.google.es/patents/ US 7354971. Acesso em: 10. ago. 2014.

NARTEN A.H., LEVY H.A. Observed Diffraction Pattern and Proposed Models of Liquid Water Science, v.165, p.447-454, 1969.

PETRIE, E. M. Handbook of Adhesives and Sealants. 2.ed. New York: McGraw-Hill, 2007. 1048p.

PIZZI, A. E.; MITTAL, K.L. Handbook of Adhesive Technology. 2.ed. Marcel Dekker Inc, 2003.

POCIUS, A. V. Adhesion and Adhesives Technology - An Introduction. Ohio: Hanser Gardner Publications Inc, 2002.

PORTO, M. E. G. Alterações de propriedades biológicas e físico-químicas da água induzidas por campos magnéticos.1998. 112 p. Dissertação (Mestrado) Universidade de Campinas, UNICAMP, Campinas, 1998. 
RISI, C. L. S. Influência nas Propriedades Elétricas devido ao Alinhamento de Nanotubos de Carbono em Matriz Epóxi Utilizando Campo Elétrico. 2010. 94 p. Dissertação (Mestrado) Universidade do Estado de Santa Catarina, UDESC, Joinville, 2010.

SKEIST, I. Handbook of Adhesives. 3 ed. New York, USA: Van Nostrand Reinhold Co, 1989.

STANDARD DIN 53563: Testing of latex - Determination of total solids content. 1998. German. Retrieved from www.beuth.de. Acesso em: 10 ago. 2014.

STUDART, A. R. Biologically inspired composites and ceramics. In: CONGRESSO BRASILEIRO DE CERÂMICA, 59., Aracaju, 2015. Plenária. Aracaju, CBC, 2015.

TECLAGO - Disponível em: www.teclago.com.br. Acesso em: 10 jul. 2015.

UENO,S.; IWASAKA, M. Magnetic Nerve Stimulation and Effects of Magnetic Fields on Biological, Physical and Chemical Processes. IEEE Trans. Magn, n. 30, p. 4698 - 4700, 1994 a.

UENO,S.; IWASAKA, M. J. Properties of diamagnetic fluid in high gradient magnetic fields. Appl. Phys., n. 75, p. 7177 - 7179, 1994 b.

VERMEIREM, J. US PATENT 2652925, 1953. 